\title{
Status of knowledge of the broad-nosed weevils of Colombia (Coleoptera, Curculionidae, Entiminae)
}

\author{
Jennifer C. Girón ${ }^{1,2}$ \\ 1 Department of Entomology, Purdue University, West Lafayette, IN, USA \\ 2 Natural Science Research Laboratory Museum of Texas Tech University, Lubbock, TX 79409, USA \\ Corresponding author: Jennifer C. Girón (entiminae@gmail.com)
}

Academic editor: P. Nunes-Silva | Received 16 October 2020 | Accepted 2 December 2020 | Published 30 December 2020

Citation: Girón JC (2020) Status of knowledge of the broad-nosed weevils of Colombia (Coleoptera, Curculionidae, Entiminae). Neotropical Biology and Conservation 15(4): 583-674. https://doi.org/10.3897/neotropical.15.59713

\begin{abstract}
Broad-nosed weevils in the subfamily Entiminae (Coleoptera: Curculionidae) are highly diverse, not only in terms of number of species, but also in their sizes, forms and colours. There are eight tribes, 50 genera and 224 entimine species recorded from Colombia: seven genera and 142 species are considered endemic and only a handful of species, which are recognised as pests of Citrus or potatoes, are broadly known. The large diversity of this subfamily in the country is only superficially known and even though genus level identifications are generally achievable, species identification remains quite challenging, due in part to limited access to broadly-scattered basic information. Summaries of available information and bibliographic resources for each of the tribes represented in Colombia are offered, along with a checklist of the species of Entiminae recorded from the country, obtained from literature and a pictorial key for tribal recognition. New combinations are proposed for eight species of the genus Lanterius Alonso-Zarazaga \& Lyal. Information on the distribution of entimine species in Colombia is compiled for the first time, including complete references to each original description and available taxonomic revisions. About a third of the species of Entiminae remain as recorded from the country without specific locality information. In addition, genus level distributional maps are presented, generated from data obtained from four Colombian entomological collections. Lastly, some challenges for entimine identification in Colombia, which likely extend throughout the Neotropical region, are briefly discussed. This contribution aims, in part, to facilitate and promote entimine research in northern South America.
\end{abstract}




\section{Resumen}

Los gorgojos de pico corto en la subfamilia Entiminae (Coleoptera: Curculionidae) son altamente diversos, no sólo en términos del número de especies, sino además en tamaños, formas y colores. Existen ocho tribus, 50 géneros y 224 especies entiminos registradas en Colombia: siete géneros y 142 especies son consideradas endémicas, y sólo un puñado, las cuales son reconocidas como plagas de cítricos o papa, son ampliamente conocidas. La gran diversidad de esta subfamilia en el país sólo se conoce superficialmente y aunque identificar géneros es generalmente alcanzable, la identificación de especies sigue siendo un desafío, debido en parte al acceso limitado a información básica ampliamente dispersa. Se ofrecen resúmenes de información disponible y recursos bibliográficos para cada una de las tribus representadas en Colombia, junto con la lista de especies de Entiminae registradas para el país, obtenida a partir de la literatura, junto con una clave pictórica para el reconocimiento de tribus. Se proponen nuevas combinaciones para ocho especies del género Lanterius Alonso-Zarazaga \& Lyal. Información sobre la distribución de las especies de Entiminae en Colombia se recopila por primera vez, incluyendo referencias completas a cada una de las descripciones originales y a las revisiones taxonómicas disponibles. Cerca de un tercio de las especies de Entiminae permanecen registradas para el país sin información específica de localidad. Adicionalmente, se presentan mapas de distribución a nivel de género, producidos a partir de datos obtenidos de cuatro colecciones entomológicas colombianas. Por último, algunas de las dificultades para la identificación de entiminos en Colombia, que probablemente se extienden a lo largo de la Región Neotropical, son brevemente discutidas. Esta contribución busca en parte facilitar y promover la investigación en Entiminae en el norte de Suramérica.

\section{Keywords}

Distribution, faunistics, literature, Neotropics, original description, South America, taxonomy

\section{Palabras clave}

Distribución, faunística, literatura, neotrópico, descripción original, Suramérica, taxonomía

\section{Introduction}

Weevils in the subfamily Entiminae Schönherr, 1823 (Schönherr 1823, col. 1138 ), commonly known as broad-nosed weevils (or "vaquitas" or "mulitas" in Spanish), constitute one of the most diverse, abundant and widespread groups of weevils worldwide, including well over 12000 described species (Oberprieler et al. 2007). The subfamily includes some of the most recognisable, charismatic and stunning weevil forms; for example, the genus Eupholus Boisduval, 1835 (Boisduval 1835, 363), from New Guinea, commonly known as "smurf-weevils" (see Van Dam et al. 2017), the genus Pachyrhynchus Germar, 1824 (Germar 1824, 336), in Southeast Asia (e.g. Háva and Rukmane 2018), sometimes called polka-dot weevils and the genera Briarius Fischer de Waldheim, 1829 (Fischer de Waldheim 1829, 88); formerly Lamprocyphus Marshall, 1922 (Marshall 1922b, 184; see Lanteri and del Río 2003) and Entimus Germar, 1817 (Germar 1817, 341), both from South America.

In taxonomic terms, the subfamily Entiminae has been recognised as such since Thompson (1992) and has been divided into as few as five tribes (Marvaldi 1997, 
1998) to as many as 55 tribes (Alonso-Zarazaga and Lyal 1999); 54 according to Bouchard et al. (2011) is the most widely-accepted number of tribes. A summary of the taxonomic history of the Entiminae is provided by Marvaldi et al. (2014).

\section{Biological generalities of entimines}

Amongst curculionids, entimines are usually easy to recognise by the typical short and broad form of their rostrum, which is accompanied, in most cases, by conspicuous mandibular scars left by the breaking off of a deciduous process of the mandible at the time when the adult emerges from the pupal stage (Anderson and Howden 2002; see Fig. 1A). Entimines are phytophagous, trending to polyphagous and oligophagous; the larvae feed underground on the roots of plants, whereas the adults feed on the leaves (Marvaldi et al. 2014). Relatively few species of entimines (considering the whole diversity of the subfamily) are recognised as pests of economical importance; usually, a species only becomes a problem when populations are large. Especially relevant for Colombia are Compsus viridivittatus (Guérin-Méneville, 1855) (Guérin-Méneville 1855, 592), a Citrus pest in the tribe Eustylini (Cano et al. 2002a, b; Gallego et al. 2012, O'Brien and Peña 2012) and the 'Potato shooter' Leschenius vulcanorum (Kirsch, 1889) (Kirsch 1889, 17) in the tribe Naupactini (Canchala 1992; Peña 2001; Cortázar Gómez et al. 2012).

A thorough summary of the natural history and morphology (of both adults and larvae) of the Entiminae is provided by Marvaldi et al. (2014). Additional information regarding morphological features of the adults and the larvae can be found in Marvaldi and Lanteri (2005) and Marvaldi (1997, 1998), respectively.

Most tribes are limited to particular biogeographic regions of the world (Marvaldi et al. 2014). Their distributions, in general, are more a reflection of habitat rather than host plant preferences (Anderson 1993, 2018; Marvaldi et al. 2014). The wide range of plants they feed on, paired with the strong association of species to particular habitats and geographic regions (e.g. Lanteri 1992; Anderson and Lanteri 2000; Franz and Girón 2009; Franz 2010b; Girón and Franz 2010; Franz 2011; Mazo-Vargas 2011, del Río and Lanteri 2011a; Girón and Franz 2012, del Río et al. 2015), makes entimines a potential model group for biogeographic studies and the identification of areas of endemism. There is also evidence of altitudinal stratification of species (Girón and Franz 2010).

As a consequence of their diversity and abundance, entimines are commonly found in the field, including urbanised areas and are, therefore, frequently found in large numbers in biological collections (see Girón and Cardona-Duque 2018). There is also a trend to find large numbers of individuals of single economically-important species in cultivars, whereas only few specimens of several different species can be found associated with forested or less disturbed areas (pers. obs.). Furthermore, it is common that specimens in collections are only identified to family or, at best, sorted to subfamily, as is often the case in Colombia (see Girón and Cardona-Duque 2018). 


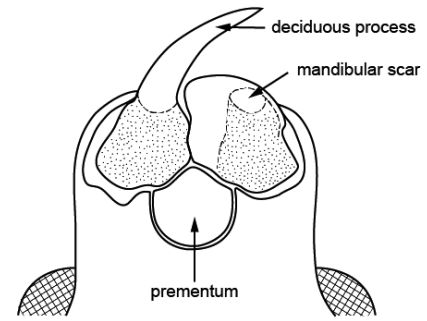

A

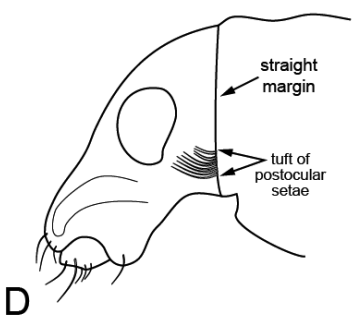

E
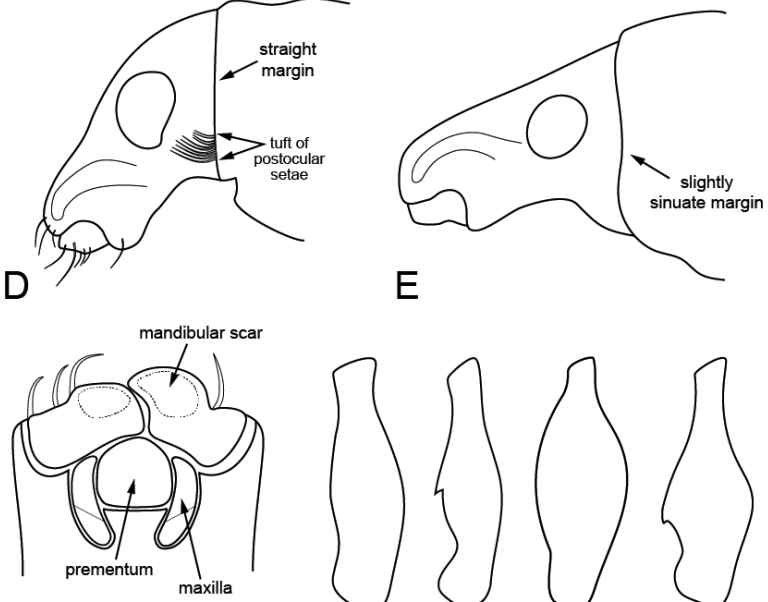

G
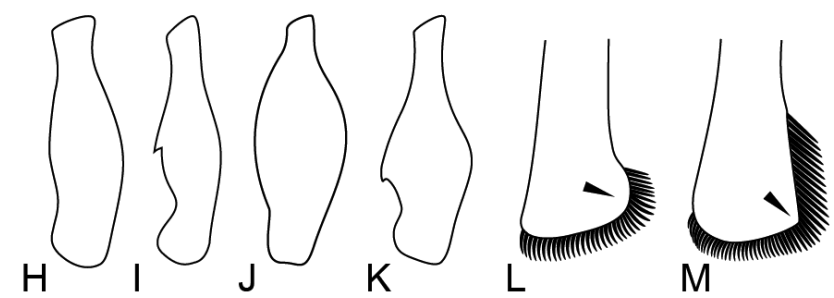

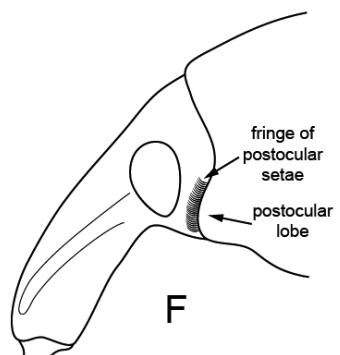

$F$

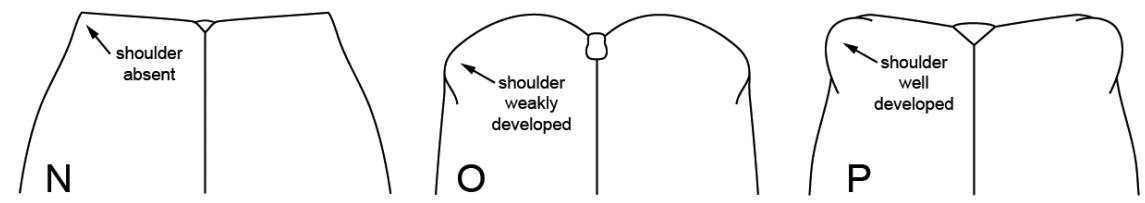

Figure 1. Select morphological features of Entiminae: A, G ventral view of rostrum: A right deciduous process still attached, left mandible with mandibular scar, maxillae fully covered by prementum (Naupactini) G mandibular scars well developed, maxillae partially covered by prementum (Anypotactus sp.) B, C frontal view of head indicating position of epistoma, nasal plate and mandibular scars: B Naupactini, with median furrow C Eustylini, with median fovea D-F lateral view of head and anterior section of prothorax: D Tanymecini, with anterior margin of prothorax straight and postocular setae clustered as a tuft E Eustylini, with anterior margin of prothorax slightly sinuate and without postocular setae F Lordopini, with anterior margin of prothorax strongly sinuate as to form welldeveloped postocular lobe, with postocular setae forming a fringe $\mathbf{H}-\mathbf{K}$ profemora in frontal view (top end of drawings articulate to coxa, bottom end articulate to tibia): $\mathbf{H}$ Compsus sp., regularly shaped profemur I Eustylus sp., toothed profemur J Hadromeropsis sp. enlarged profemur K Anypotactus sp., clavate and toothed profemur L, M apical region of left metatibia (left margin on drawing is anterior (inner) in the beetle; right margin on drawing is posterior (outer) in the beetle), black triangles indicate posterior corner of metatibia: L Eustylini, posterior corner of metatibia rounded $\mathbf{M}$ Naupactini, posterior corner of metatibia angulate $\mathbf{N}-\mathbf{P}$ anterior section of elytra in dorsal view: $\mathbf{N}$ shoulders $\mathrm{ab}$ sent $\mathbf{O}$ shoulders oblique, weakly developed $\mathbf{P}$ shoulders well developed. 


\section{Identification challenges}

One of the most relevant references for Neotropical Broad-nosed weevils is the "Biologia Centrali-Americana' by Sharp and Champion (1911), although it includes only scarce information on Colombian taxa. Even though many genera have been revised (see below under the treatment for each tribe), species identification of Neotropical and, especially northern South American, entimines remains highly challenging (e.g. Girón 2006). For Colombia, in particular, the fact that most type specimens are deposited in collections overseas, combined with the lack of identified material in national collections and compounded by a lack of specialists in the region, makes species identification a very difficult task at this time. In addition, one of the main difficulties for identifying entimine taxa is the limited access to information, which has been changing in the digital era. Many publications, including original descriptions and revisions are currently available online, some of them for free through the Biodiversity Heritage Library (https://www.biodiversitylibrary.org/). Nevertheless, some key publications with full references linking to those original descriptions (e.g. Wibmer and O’Brien 1986a; Alonso-Zarazaga and Lyal 1999) remain available only on paper and are essentially inaccessible to the broad community, especially in Latin American countries. An effort has been made in this paper to incorporate references and links to as many relevant publications as possible.

This contribution compiles and summarises the available information for the Entiminae recorded from Colombia. A general pictorial key to diagnose tribes is given. For each tribe represented in the country, a list of morphological characters for tribal recognition is offered, along with distributional information and bibliographic resources. A list of species is provided, including bibliographic records of distributional data within the country, where available. In addition, genus-level information has been recorded from specimens identified in Colombian national entomological collections, further providing information about distributions of entimines in the country.

\section{Materials and methods}

\section{Species list}

The list of species of Entiminae recorded from Colombia, as well as general species distributions, were extracted from the annotated checklist of the weevils of South America by Wibmer and O'Brien (1986a), the list of species of Entiminae by Morrone (1999), in addition to more recent revisions or new descriptions, where available. Tribal concepts and general distributions of genera are in accordance with Alonso-Zarazaga and Lyal (1999). The full list of species is included here as Suppl. material 1 and available as a checklist via GBIF (Girón 2020, https://doi. org/10.15472/jdwfao); this online resource will be updated whenever new species are added to the Colombian fauna of Entiminae. 
Only presence in Colombia was obtained from the main references (Wibmer and O'Brien 1986a; Morrone 1999 and Alonso-Zarazaga and Lyal 1999); therefore, original descriptions for each species were checked to obtain distributional records within the country. Localities taken from the 1800s' to mid-1900s' publications might not reflect current departments or municipalities (e.g. 'Bogotá' as a locality in 1857 does not strictly correspond to current 'Cundinamarca: Bogota'). In those cases, locality is quoted as presented in the original description. Department was added for unambiguous localities (e.g. Antioquia was added to original localities recorded as 'Medellin'; Cundinamarca added for Fusagasugá; Meta added for Villavicencio, Boyacá added for Muzo). Localities in square brackets '[]' in the list of species indicate locality spelling in the original description. Type locality is recorded as 'Bogotá for species described by Kirsch (1868) given the title of the paper: "Beiträge zur Käferfauna von Bogotà". A question mark '?' indicates that the locality record is doubtful and needs confirmation. Specific localities from countries other than Colombia are omitted here. For some of Schönherr's taxa, the page number corresponds to a column number in the publication and is indicated by 'col'. (e.g. Entiminae Schönherr 1823, col. 1138).

\section{Material examined}

Specimens from entomological collections in Colombia were revised and distributional data at the generic level were recorded (Suppl. material 2). The insect collection abbreviations are adopted, for the most part, from Evenhuis (2020) as follows:

IAvH Instituto Alexander von Humboldt, Villa de Leyva, Colombia, https:// doi.org/10.15472/vmpedy [databased July 2013]

MEPB Museo Entomológico de Piedras Blancas, Comfenalco Antioquia, Colombia, https://doi.org/10.15472/xblw2v [databased March 2013]

MPUJ Museo Javeriano de Historia Natural Lorenzo Uribe, S.J., Bogotá, Colombia, https://doi.org/10.15472/xmukx8 [partly databased October 2015]

MUSENUV MuseodeEntomologíadela Universidaddel Valle,Cali,Colombia,https:// www.gbif.org/publisher/85be57ed-f187-49c9-b7ff-eaa622e06217 [databased December 2006]

A few additional records were obtained from ASUCOB (Arizona State University Charles W. O’Brien Collection, Arizona, USA https://doi.org/10.15468/eeqtx0). Information obtained from collections is summarised for each tribe and identified genus.

Genus-level identifications were obtained using available keys (van Emden 1944a, b) and diagnoses (Sharp and Champion 1911) and confirmed by consulting experts in Curculionidae (Dr. Robert Anderson, Canadian Museum of Natural History, Ottawa, Canada and Dr. Charles O'Brien, USA), who have access to reference collections. The recognition section presented here for each tribe applies to entimines seen in Colombian collections and might not reflect the entire variation across tribes and genera. In most cases, there is more than one morphospecies with- 
in each genus at each collection. Species were not identified. There remain specimens recognised as entimines, but not identified to tribe. Relevant information for entimine tribes represented in Colombia was compiled and is presented here. A general pictorial key is provided here just as a way to narrow down identifications (Fig. 2). Preliminary identifications using this key should be checked against the lists of characters offered for each tribe for confirmation.

\section{Figures}

Line drawings were produced by tracing over photographs into drawing software. Figures are grouped to show morphological variation or to keep relevant tribal information together. Maps are based on data from collections. The record density map (Fig. 3) was created using $\mathrm{R}$ version 3.5.2 ( $\mathrm{R}$ Core Team 2018), interfaced through RStudio version 1.1.463 (RStudio Team 2016) with the R package 'tmap' (Tennekes 2018). Distribution maps in Figs 3-10 were created using SimpleMappr (Shorthouse 2010); each map is accompanied by sketches of the general appearance of the head in dorsal view of some representative specimens of the tribe as seen in Colombian collections.

\section{Results}

There are eight tribes, 50 genera, and 224 species of Entiminae recorded from Colombia. Seven genera and 142 species are considered endemic to the country (Wibmer and O'Brien 1986a; Morrone 1999; Girón and Cardona-Duque 2018; see species list, Suppl. material 1 or Girón 2020 - https://doi.org/10.15472/jdwfao). A general pictorial key to recognise these eight tribes is presented in Fig. 2. The list of species with their distribution in Colombia is presented. The genera Pandeleteius Schönherr, 1834 (Schönherr 1834, 129; Tanymecini, 44 spp.), Compsus Schönherr, 1823 (Schönherr 1823, col. 1140; Eustylini, 39 spp.), Hypsonotus Germar, 1824 (Germar 1824, 367; Lordopini, 17 spp.) and Exorides Pascoe, 1881: 43 (Pascoe 1881, 43; Eustylini, 14 spp.) are the most diversein the country (numbers in parentheses indicate numbers of species recorded from Colombia).

\section{Diversity by department}

A total of 749 records of entimines were obtained from the revised collections (Suppl. material 2), with 248 (33\%) from Valle del Cauca, followed by Magdalena $(75,10 \%)$, Antioquia (62, 8.3\%), Risaralda (48, 6.4\%), Boyacá (47, 6.3\%), Nariño (35, 4.7\%), Bolívar (31, 4.1\%), Meta (27, 3.6\%), Quindío (22, 3\%), Cauca, Cundinamarca and Amazonas, each with 18 records (2.4\%), followed by Tolima (11, 1.5\%), Chocó $(9,1.2 \%)$, Santander $(7,1 \%)$, Putumayo and Vaupés with 6 each $(0.8 \%)$, Norte de Santander $(5,0.7 \%)$, Vichada $(3,0.4 \%)$, Guaviare $(2,0.3)$ and Cesar with only one record $(0.1 \%)$. The Departments of Atlántico, Caquetá, Córdoba, Huila, La Guajira, Sucre, Arauca, Guainía and San Andres, Providencia and Santa Catalina have no entimine ocurrences from the studied collections (Fig. 2). 


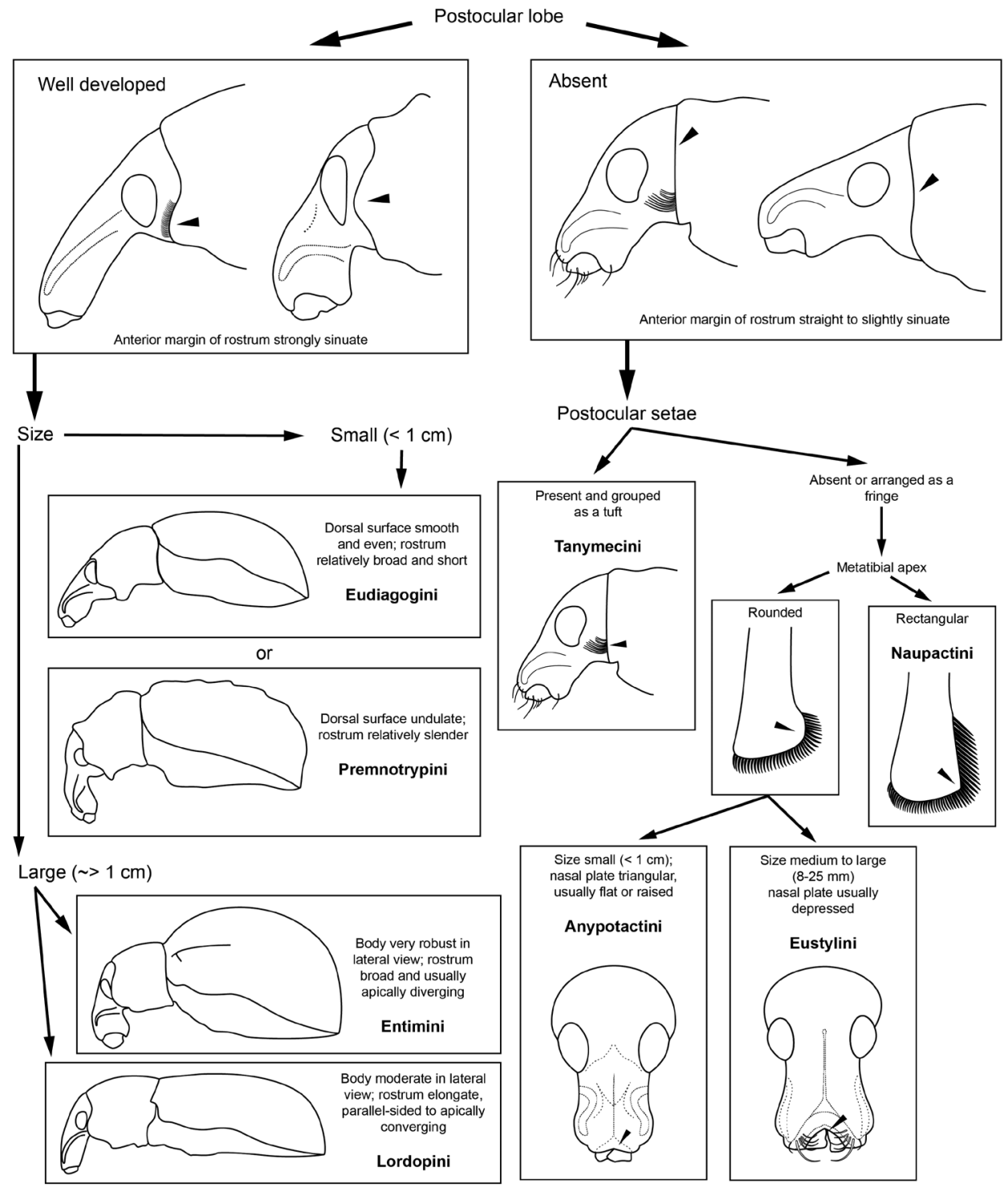

Figure 2. Pictorial key for the recognition of Tribes represented in Colombia. Preliminary identifications achieved using this key should be checked against the lists of characters offered for each tribe for confirmation.

\section{Tribe Anypotactini Champion, 1911}

Fig. 4

Recognition. Usually small (approx. 4-11 mm); scale coverage composed by appressed, mostly non-overlapping scales, usually uniform (in density and colour), usually brown (some species iridescent green or blue); usually with thick and erect 


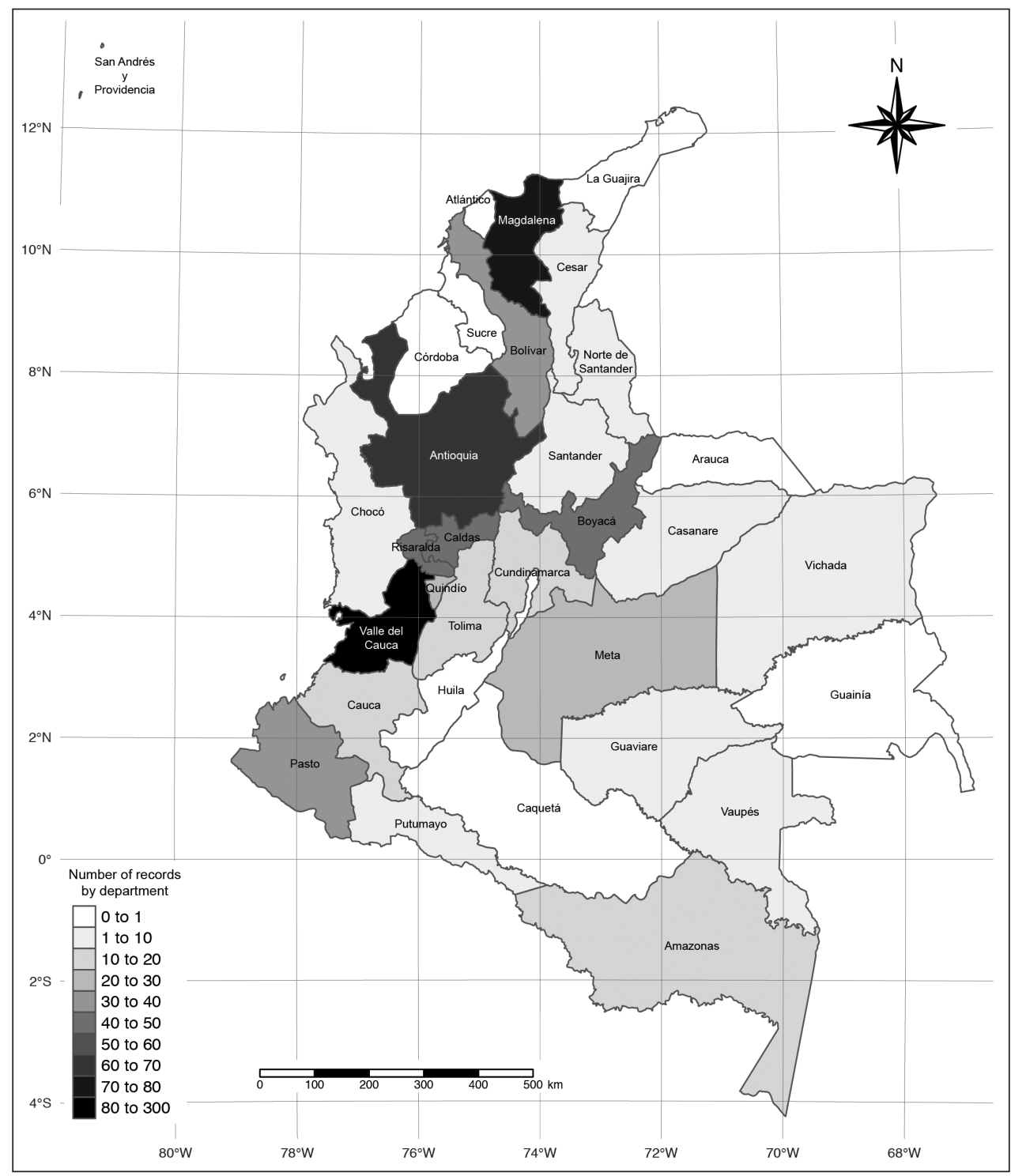

Figure 3. Record density map of Entiminae in Colombia. The colour gradient in the map represents the number of records by Department recorded from entomological collections (see Materials and Methods). Departments in white indicate no records and Departments increasingly darker with larger numbers of records (numbers in parentheses): Valle del Cauca (248), Magdalena (75), Antioquia (62), Risaralda (48), Boyacá (47), Nariño (35), Bolívar (31), Meta (27), Quindío (22), Cauca, Cundinamarca and Amazonas, (18 each), Tolima (11), Chocó (9), Santander (7), Putumayo and Vaupés (6 each), Norte de Santander (5), Vichada (3), Guaviare (2) and Cesar (1). Atlántico, Caquetá, Córdoba, Huila, La Guajira, Sucre, Arauca, Guainía and San Andres, Providencia and Santa Catalina have no entimine ocurrences from the studied collections. The data used to create this map are available in Suppl. material 2. 
scale-like setae, rather uniformly distributed all over the surface; head (including rostrum) subrectangular [e.g. some Anypotactus Schönherr, 1840 (Schönherr 1840b, 299; Fig. 4B) and Polydacrys Schönherr, 1834 (Schönherr 1834, 130; Fig. 4D)] to conical [Phanasora Pascoe, 1881 (Pascoe 1881, 38; Fig. 4C), Prepodellus Kirsch, 1868 (Kirsch 1868, 239) and some Anypotactus], usually longer than wide; surface of rostrum flat, depressed or undulate, often with longitudinal carinae (Fig. 4B-D); nasal plate well developed (see Fig. 1B, C), forming an elevated, large and smooth plate in Polydacrys (Fig. 4D); mentum not covering the maxillae completely (Fig. 1G; except in Polydacrys, see Fig. 1A); antennal scape slender, at rest passing well below eye, often reaching or surpassing anterior margin of prothorax; anterior margin of prothorax in lateral view straight to oblique, never forming postocular lobe, lacking postocular setae [except in Hyphantus Germar, 1824 (Germar 1824, 334)]; elytral shoulders and hindwings weakly- to well-developed (Fig. 1N-P); legs relatively slender, femora clavate, often toothed (Fig. 1K).

Anypotactines can be confused with some small Naupactini, from which they can be recognised by the shape of the apical region of the metatibia, which is rectangular and fringed by flat spines along ventral and posterior margins in Naupactini (Fig. 1M, rounded in Anypotactini, see Fig. 1L). The general appearance of some Anypotactini resembles members of Tanymecini (Fig. 1D, with postocular setae) and can be differentiated, most of the time, by the lack of postocular setae in Anypotactini.

Diversity. The tribe contains 11 extant genera with 81 species described, all distributed in the New World (Wibmer and O'Brien 1986a, 44, Alonso-Zarazaga and Lyal 1999, 145). Seven genera represented by 11 species have been recorded from Colombia. Hypsometopus Kirsch, 1868 (Kirsch 1868, 223), represented by a single species, is considered endemic to the country; seven additional anypotactine species are considered endemic as well.

General distribution. The tribe ranges from south-western USA to Argentina and Chile and some Caribbean islands, including the following countries: Argentina, Bolivia, Brazil, Chile, Colombia, Ecuador, Peru, Paraguay, Uruguay, Venezuela; Belize, Costa Rica, El Salvador, Guatemala, Honduras, Mexico, Nicaragua, Panama; Cuba, Dominica, Granada, Guadeloupe, Puerto Rico, Saint Vincent; SW USA (Texas) (Alonso-Zarazaga and Lyal 1999). Most genera are distributed in Central America and northern South America, but the largest genus, Hyphantus Germar, 1824 (Germar 1824, 334; 45 species; see Vaurie 1963), is distributed in southern Brazil, Argentina, Paraguay and Uruguay.

Distribution in Colombia. Within the revised collections, anypotactines were recorded from Bolívar, Boyacá, Caldas, Cundinamarca, Magdalena, Quindío, Risaralda, Santander and Valle del Cauca (Fig. 4A). Anypotactus and Polydacrys were the most commonly found anypotactine genera in the revised collections; other anypotactines were found but remain identified to tribe only (Suppl. material 2; Fig. 4A).

Bibliographic resources. The best resource available for the tribe as a whole is the Biologia Centrali-Americana (Sharp and Champion 1911, 215, as 'Anypotactina'). It includes a brief diagnosis of the tribe and diagnoses of the Central American 

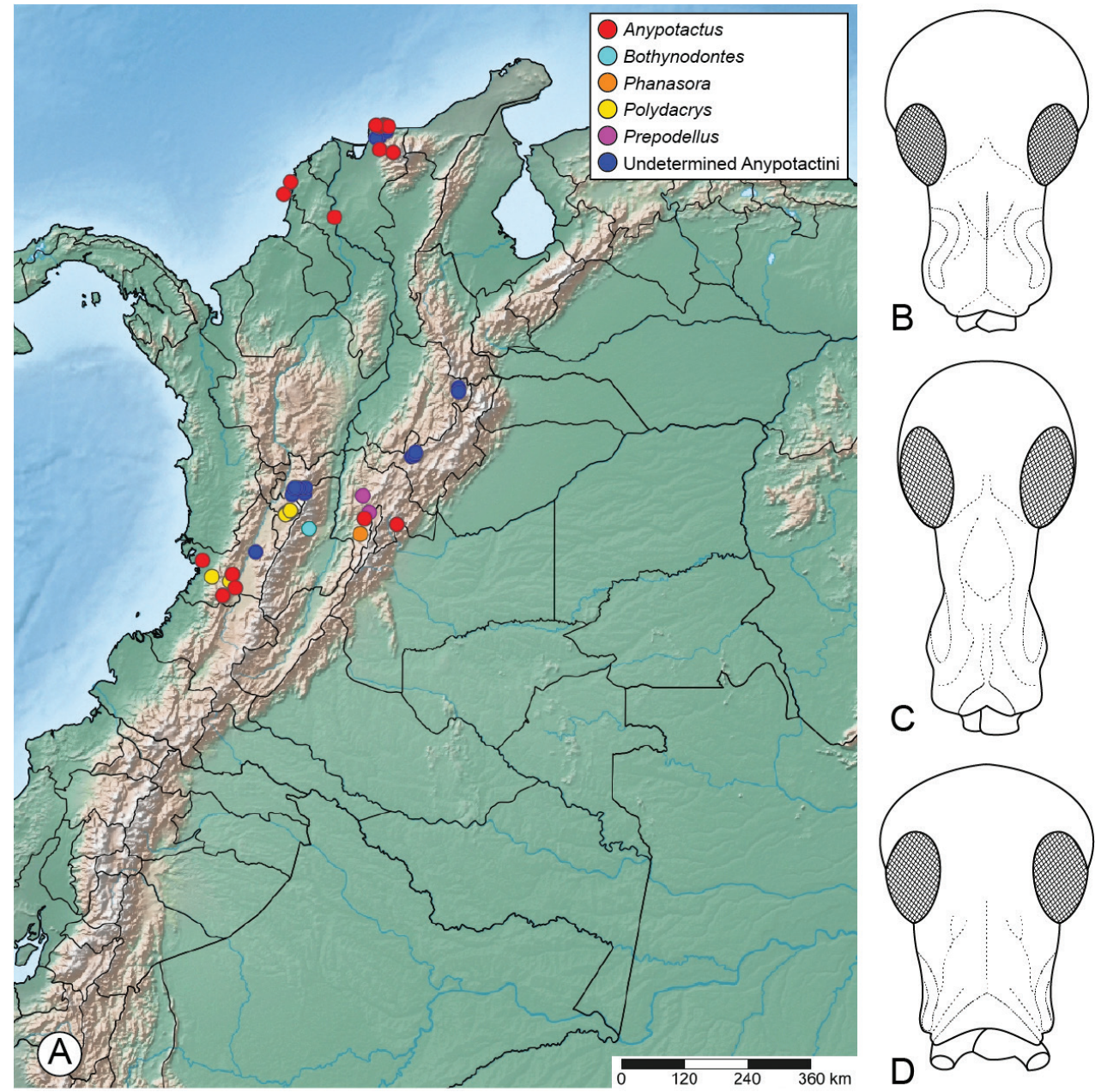

Figure 4. Distribution and some head variants of Anypotactini: A distribution map of records for Anypotactus, Bothynodontes, Phanasora, Polydacrys, Prepodellus and undetermined Anypotactini in Colombia B-D head in dorsal view: B Anypotactus C Phanasora D Polydacrys.

genera and species (with some keys). There is a key in van Emden (1944b, 506) to identify the tribe, as well as a key to genera (van Emden 1944b, 510). The only genus of the tribe that has been revised is Hyphantus (Vaurie 1963), but it is not represented in Colombia.

Natural history. Except for a few plant-association records for Hyphantus (Vaurie 1963) and records of an unidentified species of Bothynodontes on Alnus jorullensis (Betulaceae) in Caldas and Baccharis sp. (Asteraceae) in Tolima (Bustillo and Villegas Isaza 1986), the natural history of Anypotactini remains largely unknown.

Remarks. A large proportion of anypotactine records in Colombia are concentrated in the mountainous regions (Fig. 4A). Some specimens amongst the undetermined 
Anypotactini from Caldas (Manizales, Río Blanco; MUSENUV) likely belong to an undescribed genus (Dr. Robert Anderson, pers. comm.). Specimens recorded from lowlands, especially from the north coast, share affinities with material seen from Central America at ASUCOB. One species of Anypotactus was included in a morphologybased phylogenetic analysis (Girón and Franz 2010), resulting as sister to Apodrosus Marshall, 1922 (Marshall 1922a, 59; Polydrusini, exclusively Caribbean); no anypotactines have been included in molecular-based phylogenetic analyses to date.

\section{Tribe Entimini Schönherr, 1823}

Fig. 5

Recognition. Medium to large (approx. 7-45 mm), often very robust; scale coverage either nearly uniform and dense or forming patches across surface, highly variable in colouration including brown, white, purple and iridescent tones of green and blue; head (including rostrum) subrectangular, usually longer than wide (Fig. 5B, C); rostrum usually apically broadened (Fig. 5C); anterior margin of prothorax in lateral view strongly sinuate forming conspicuous postocular lobe (Fig. 5D), often with fringe of postocular setae (Fig. 5D); elytral shoulders well developed, sometimes projected from general outline of body; hindwings well-developed; surface of elytra may be granulate or bear protuberances or tubercles.

Members of Entimini are generally easily distinguishable by their usually large size and the general bulky shape of their bodies [Cydianerus Schönherr, 1840 (Schönherr 1840a, 737), Entimus, Polyteles Germar, 1829 (Germar 1829, 358)] or the characteristic shape of their heads with narrow frons and rostrum with lateral margins apically diverging [Cydianerus, Rhigus Schönherr, 1823 (Schönherr 1823, col. 1138)]. A more detailed diagnosis is offered by Vaurie (1951).

Diversity. The tribe contains seven Neotropical genera with 46 species described to date, two of them fossil (Wibmer and O'Brien 1986a, 99, Gaiger 2001; Morrone 2002; Vanin and Gaiger 2005; Poinar et al. 2017). Three genera, represented by four species, have been recorded from Colombia, one of them fossil (Poinar et al. 2017).

General distribution. The tribe ranges from Mexico to Argentina, with no representatives in the Caribbean islands. Entimini can be found in the following countries: Argentina, Bolivia, Brazil, Colombia, Ecuador, French Guiana, Guyana, Paraguay, Peru, Uruguay, Venezuela; Costa Rica, El Salvador, Honduras, Mexico, Nicaragua, and Panama (Alonso-Zarazaga and Lyal 1999). All genera are mainly represented in Brazil.

Distribution in Colombia. In Colombian collections, representatives of Entimini (genus Rhigus) have been recorded from Amazonas and Tolima (Girón and Cardona-Duque 2018, 181). The distribution in the country for the rest of Colombian Entimini has not been recorded in literature. There is one record of the genus Cydianerus from Sucre in iNaturalist (https://www.inaturalist.org/observations/39591579). 


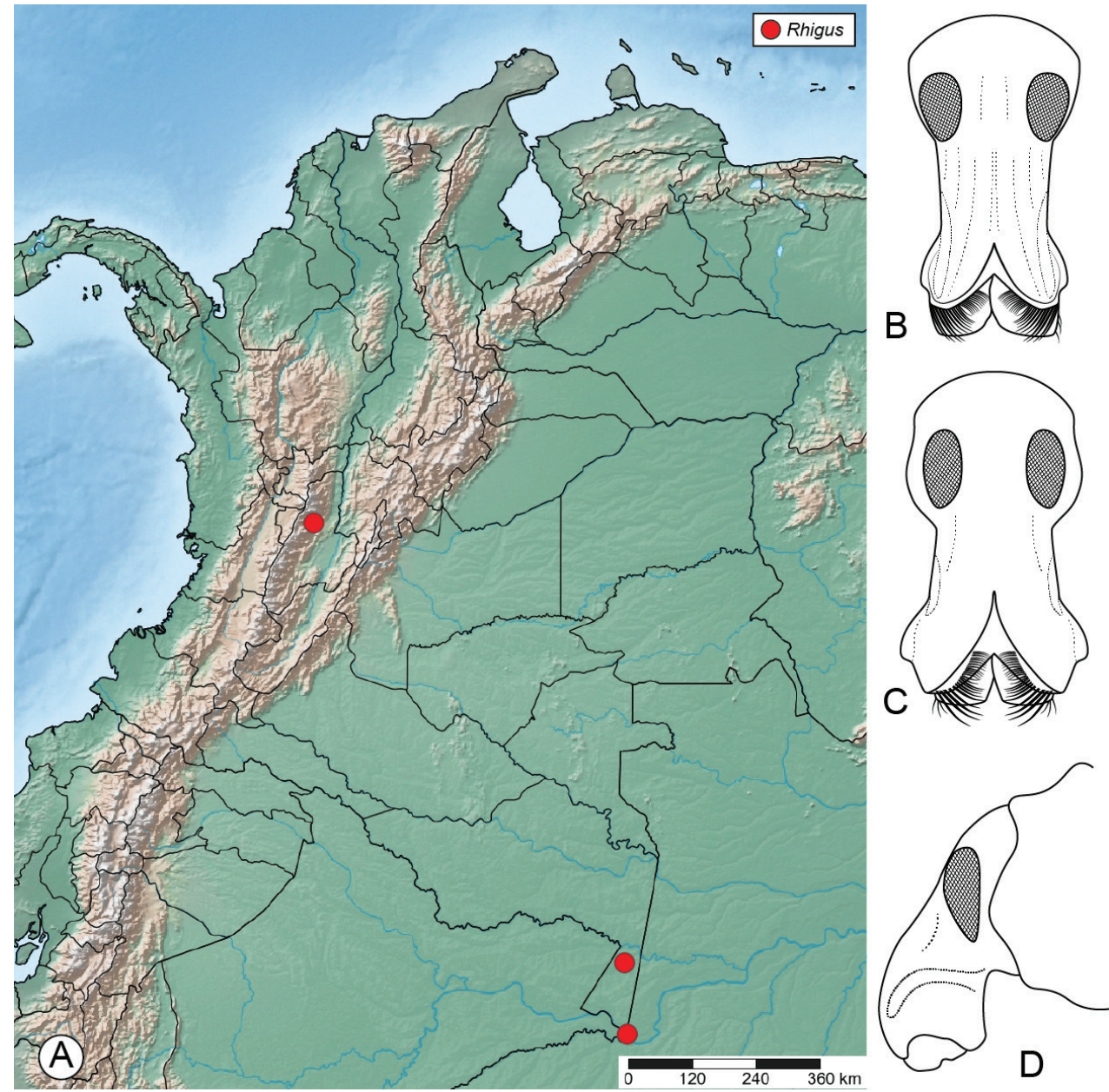

Figure 5. Distribution and some head variants of Entimini: A distribution map of records for Rhigus in Colombia B, C head in dorsal view: B Entimus $\mathbf{C}$ Rhigus $\mathbf{D}$ head and anterior section of prothorax in lateral view of Rhigus showing well-developed postocular lobe.

Bibliographic resources. Entimini is one of the better-studied groups of Neotropical broad-nosed weevils. Sharp and Champion $(1911,300)$, with emphasis on Central American fauna, offer some diagnostic features for a wider concept of Entimini (as 'Entimina') which includes some genera currently placed elsewhere. Bovie (1908a, 2) offered a key to genera including illustrations (Bovie 1908a, plate 9). Morrone (1999) treated 'Entimina' in a broader sense, including 'Entimina,' 'Lordopina, 'Hypsonotina', 'Promecopina' and 'Eudiagogina' of Wibmer and O'Brien (1986a). Some genera of the tribe have been revised: Entimus (Vaurie 1951; Morrone 2002), Rhigus (Gaiger 2001) and Phaedropus Schönherr, 1823 (Schönherr 1823, col. 1140; Vanin 1983; not recorded from Colombia). A morphology-based phylogeny, key to the current genera and details on their morphology were presented by Vanin and Gaiger (2005). 
Remarks. Even though members of Entimini are amongst the largest and most striking weevils in the subfamily, they are extremely rare in Colombian collections; only a few specimens of Rhigus have been found in the revised collections along with a few other unidentified Entimini. Romo and Morrone (2011) analysed biogeographic trends in the tribe. With the exception of the life cycle for Entimus nobilis (Olivier, 1790) (Olivier 1790, 525, Bruch 1932), the natural history of members of Entimini remains largely unknown. Plant associations have only been recorded for one species of Phaedropus (Vanin 1983) and one species of Rhigus (Gaiger 2001). There is one fossil species of Cydianerus recently described from Colombia (Poinar et al. 2017) and one fossil species of Entimus described from the USA (Scudder 1876). There is a recent study on the morphological variation and sexual dimorphism in Cydianerus latruncularius (Perty, 1832) (Perty 1832, 70, Regueira et al. 2020). Rhigus speciosus has been recently recorded from Colombia (Girón and Cardona-Duque 2018) and Peru (Gillett and Barr 2020). The type species for Entimus, Entimus imperialis Forster, 1771 (Forster 1771, 34), has been the focus of studies regarding the structural colouration of its scales which, as in other entimines, contain three-dimensional photonic crystals with diamond-type structure (e.g. Wilts et al. 2012). Polyteles Germar, 1829 (Germar 1829, 358) has not been recorded from Colombia, but its presence in the south of the country is likely, given that the genus is distributed in Argentina, Bolivia, Brazil, Ecuador, Paraguay, Peru and Uruguay.

\section{Tribe Eudiagogini LeConte, 1874}

Fig. 6

Recognition. Small weevils (approx. 3-8 mm); scale coverage usually light to dark brown, forming patterns on dorsal surface; iridescent areas with blue or green scales or reddish or yellowish stripes may be present in some genera; setae along surface may also be present; surface of body smooth and even; head (including rostrum) subrectangular, usually nearly as long as wide (Fig. 6B, C); rostrum robust, usually nearly parallel-sided (Fig. 6B, C); nasal plate (see Fig. 1B, C) usually well developed; anterior margin of prothorax in lateral view strongly sinuate forming conspicuous broad postocular lobe (Fig. 6D); elytral shoulders moderately to well-developed (e.g. Fig. 1O, P); legs relatively stout, femora never toothed [except in Eurysaces Schönherr, 1840 (Schönherr 1840b, 313), not present in Colombia].

Eudiagogines are easily recognisable by their small size, well-developed postocular lobes and overall robustness. They could potentially be confused with anypotactines because of their size, but their postocular lobe sets eudiagogines apart. They can resemble some small Entimini, but eudiagogines have a comparatively shorter and stouter rostrum. Additional characters to define the tribe can be found in Lacordaire (1863, 384, in French).

Diversity. The tribe contains ten extant genera with 100 species (including two fossil species in Dominican amber; Poinar and Brown 2011; Poinar and Legalov 2017) 


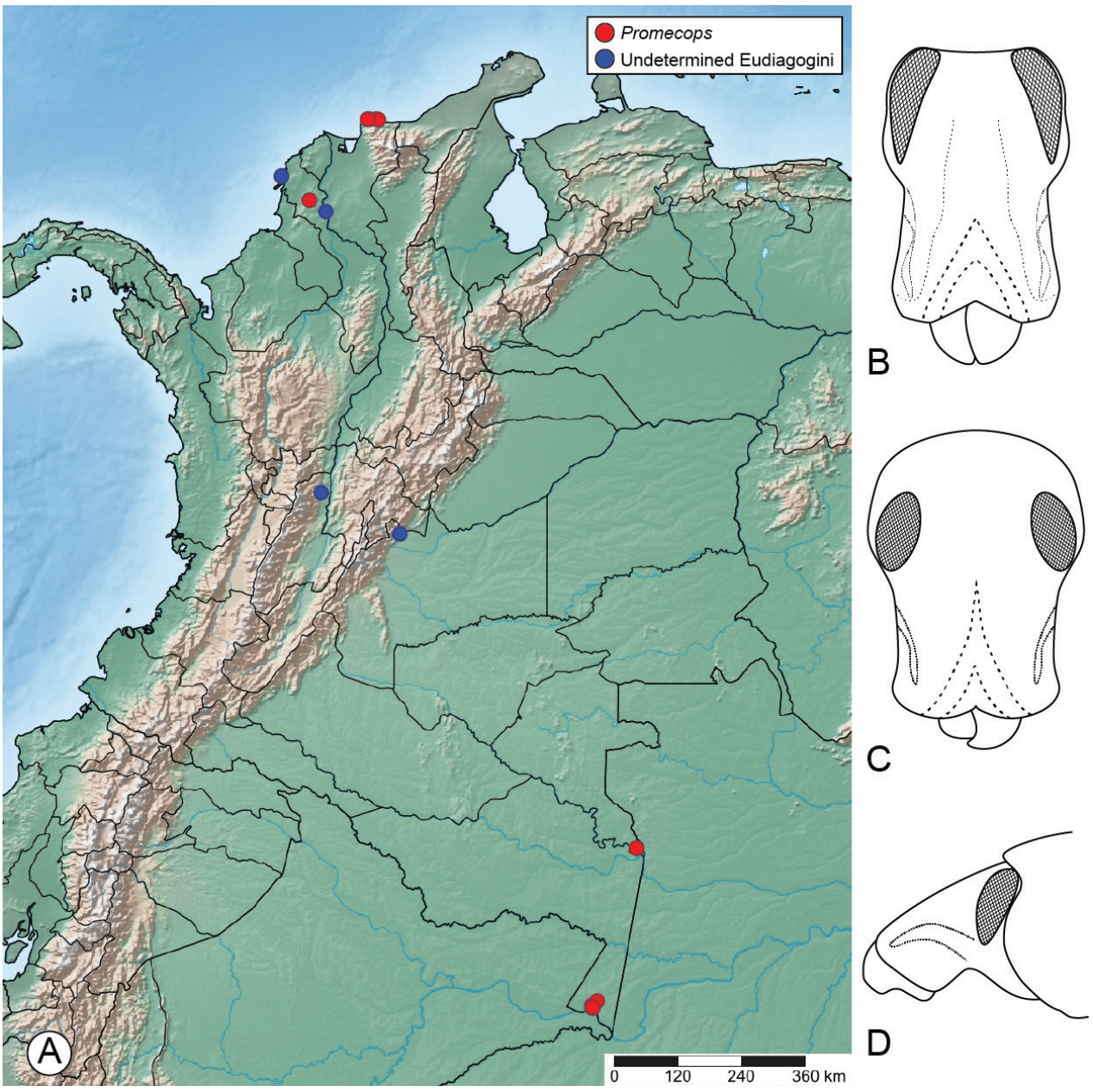

Figure 6. Distribution and some head variants of Eudiagogini: A distribution map of records for Promecops and undetermined eudiagogines in Colombia B, C head in dorsal view: B Promecops C Colecerus D head and anterior section of prothorax in lateral view of Promecops showing welldeveloped postocular lobe.

described to date, all distributed in the New World (as 'Promecopini' in Wibmer and O’Brien 1986a, 81, O’Brien and Kovarik 2001). Two genera, Colecerus Schönherr, 1840 (Schönherr 1840a, 927) and Promecops Sahlberg, 1823 (Sahlberg 1823, 30), represented by six species, have been recorded from Colombia; four species are endemic.

General distribution. The tribe ranges from the USA to Argentina, including some Caribbean islands. Eudiagogini can be found in the following countries: Argentina, Bolivia, Brazil, Chile, Colombia, Ecuador, French Guiana, Guyana, Paraguay, Peru, Uruguay, Venezuela; Belize, Costa Rica, El Salvador, Guatemala, Honduras, Mexico, Nicaragua, Panama; Grenadines, Guadeloupe, St. Vincent; NC, NE, SE, SW USA (Alonso-Zarazaga and Lyal 1999). 
Distribution in Colombia. Representatives of the tribe have been recorded in collections from Amazonas, Bolívar, Chocó, Magdalena, Meta, Risaralda, Tolima, Valle del Cauca, and Vaupés (Suppl. material 2, Fig. 6A).

Bibliographic resources. The original diagnosis for Eudiagogini (then named Promécopides) was given by Lacordaire (1863, 384, in French). In the Biologia Centrali-Americana (Sharp and Champion 1911,300) eudiagogine genera were considered part of an extended concept of Entimini (as 'Entimina'). Morrone (1999) treated 'Eudiagogina' and 'Promecopina' as part of 'Entimina'. A revision of Eudiagogus Schönherr, 1840 (Schönherr 1840b, 307), was published by Warner (1979). LeConte and Horn $(1876,108)$ treated the genera recorded from North America. Voss $(1934$, 74, in German, as 'Promecopina'), provided a key to genera (containing genera of Entimini) and keys to species for some eudiagogine genera.

Remarks. Promecops contains over $60 \%$ of the species and is also the most widespread genus of the tribe; some species are considered economically important in soybean cultivars in Argentina (Lázaro et al. 1997, 1998) and Brazil (Rocha Barreto and Cavalet 2016). One species of Colecerus has been associated with cultivated Pecan trees in Mexico (Soto-Hernández and Barros-Barrios 2018). In North America, Eudiagogus has been associated with legumes in the genus Sesbania (Warner 1979); Eudiagogus has not been recorded from Colombia, but its presence in the south of the country is likely, given that the genus is distributed in Argentina, Bolivia, Brazil, Ecuador, Paraguay, Peru, Uruguay, Costa Rica, Honduras, Mexico and USA. Promecops is the only eudiagogine genus recorded from the revised Colombian collections; other eudiagogines were located, but remain undetermined (Suppl. material 2, Fig. 6A).

\section{Tribe Eustylini Lacordaire, 1863}

Fig. 7

Recognition. Medium to large weevils (approx. 10-25 mm); scale coverage highly variable in presence, density and colouration; iridescent scales, erect setae or waxy secretions are frequently present; surface smooth and even or strongly sculptured and irregular; head (including rostrum; Fig. 7C-F) subrectangular, nearly as long or longer than wide; eyes small to mid-sized, slightly dorsally positioned; frons usually as wide as or narrower than interantennal distance, often bearing median fovea (see Fig. 1C); rostrum nearly parallel-sided or broadened apically; dorsal surface of rostrum with variable elevations or depressions, including longitudinal carinae or oblique fossae; antennal scrobe generally fully visible in dorsal view (Fig. 7C-F); nasal plate (see Fig. 1B, C) usually well developed, either depressed, flat or elevated regarding surface of rostrum; anterior margin of prothorax in lateral view straight, seldom slightly sinuate (Fig. 1E), never forming conspicuous postocular lobe; postocular setae may be present, if so, forming a fringe instead of a tuft (compare Fig. 1D vs. 1F); elytral shoulders usually well-developed, absent in Brachyomus La- 

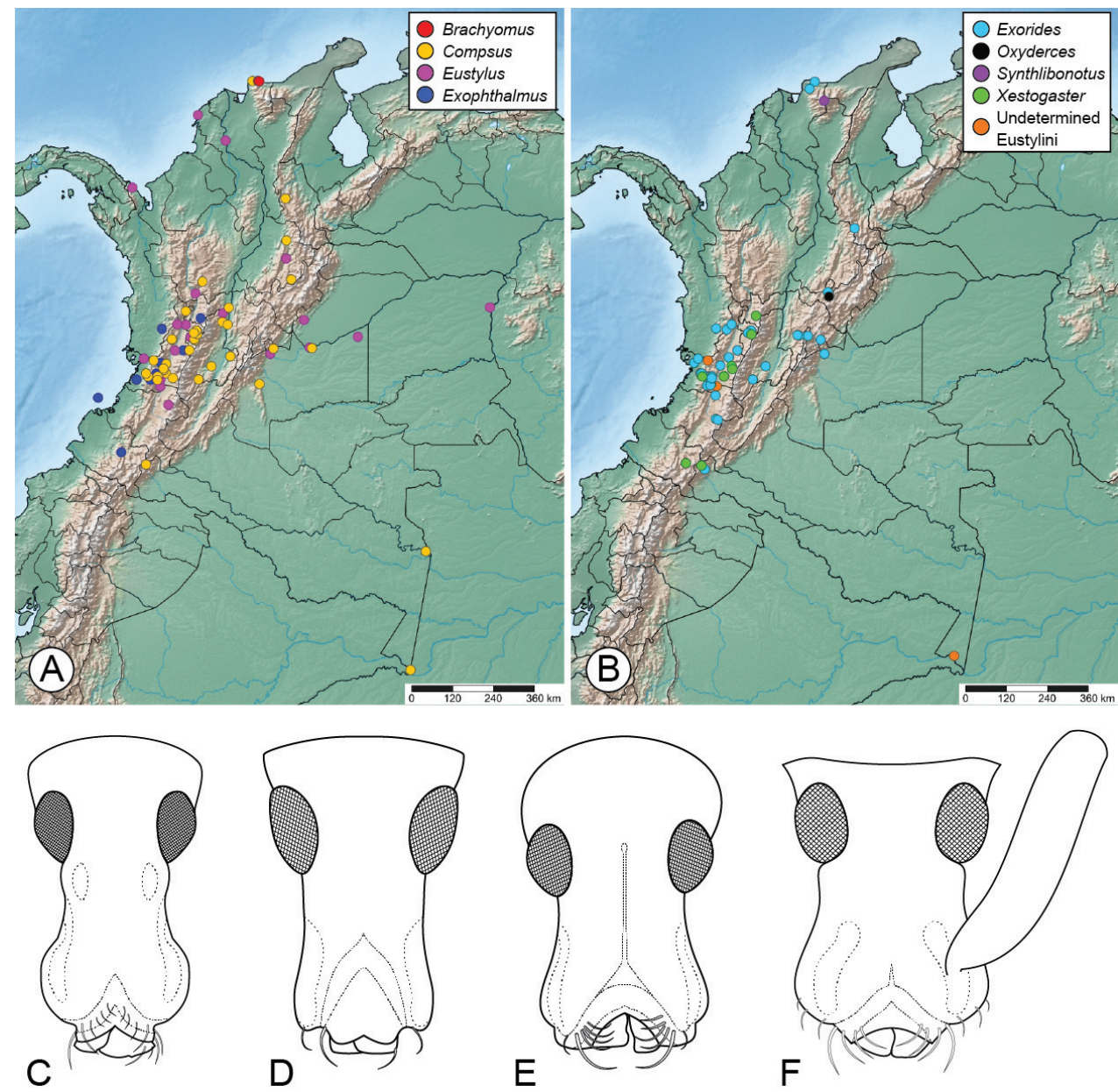

Figure 7. Distribution and some head variants of Eustylini: A, B distribution maps of Eustylini in Colombia: A records for Brachyomus, Compsus, Eustylus and Exophthalmus B records for Exorides, Oxyderces, Synthlibonotus, Xestogaster and undetermined eustylines $\mathbf{C}-\mathbf{F}$ head in dorsal view: C Exophthalmus D Synthlibonotus E Exorides $\mathbf{F}$ Eustylus with characteristic broad antennal scape.

cordaire, 1863 (Lacordaire 1863, 130), reduced in some Compsus and Exorides Pascoe, 1881 (Pascoe 1881, 43) (see Fig. 1N-P); tubercles and apical projections may be present on elytra; femora usually not toothed (Fig. 1H; except in some Eustylus Schönherr, 1842 (Schönherr 1842, 40), Fig. 1I).

Eustylines are relatively easy to recognise amongst South American entimines by their size, frequently iridescent/bright colourations and the shape of their head (Fig. 7C-F). They may be confused with similarly-coloured Naupactini, but the shape of the head, eyes, nasal plate and apex of metatibia [compare Fig. 1L (Eustylini) vs. $1 \mathrm{M}$ (Naupactini)] differentiate them. 
Diversity. Eustylini contains 25 genera with 336 species described to date. Eight genera, represented by 73 species, have been recorded from Colombia, 52 of which are endemic.

General distribution. Eustylini ranges from south-western USA to Argentina, with its highest diversity in the Caribbean, Central America and northern South America, including the following countries: Argentina, Bolivia, Brazil, Colombia, Ecuador (incl. Galapagos Islands), French Guiana, Guyana, Paraguay, Peru, Surinam, Trinidad, Venezuela; Belize, Costa Rica (incl. Cocos Island), El Salvador, Guatemala, Honduras, Mexico, Nicaragua, Panama; Antigua, Barbados, Cuba, Dominica, Dominican Republic, Guadeloupe, Haiti, Hispaniola, Jamaica, Martinique, Montserrat, Nevis, Puerto Rico (incl. Mona Is., Vieques Is.), St. Barthelemy, St. Croix, St. Kitts, St. Lucia, St. Thomas, St. Vincent; NC, NE, SE, SW USA (AlonsoZarazaga and Lyal 1999).

Distribution in Colombia. Representatives of the tribe have been recorded from 21 Departments in the Country: Amazonas, Antioquia, Bolívar, Boyacá, Caldas, Casanare, Cauca, Chocó, Cundinamarca, Magdalena, Meta, Nariño, Norte de Santander, Putumayo, Quindío, Risaralda, Santander, Tolima, Valle del Cauca, Vaupés and Vichada (Suppl. material 2).

Bibliographic resources. The Biologia Centrali-Americana (Sharp and Champion 1911) may be a good place to start understanding the diversity of Eustylini (as 'Exophthalmina', p. 247 and 'Playomina', p. 282). There is a key to identify species of Brachyomus in Faust (1893, 16, in German). Marshall (1922b) discusses several classification issues with Compsus, Exophthalmus Schönherr, 1823 (Schönherr 1823, col. 1140) and allies, describes new genera and species and presents a key to identify species of Exorides (p. 203). Hustache (1938a, in French) revised part of South American Compsus; O'Brien and Peña (2012) translated to English and modified Hustache's key and provided identification and records for two species of Compsus recorded as Citrus pests in Colombia. Franz (2010a) re-described several type species in Eustylini and presented a morphology-based phylogeny of the so called "Exophthalmus genus complex", which involves several eustyline genera, especially Central American and Caribbean groups. Girón and Chamorro (2020) defined the "Compsus genus complex" and discussed affinities amongst species in this group. Some eustylines were included in phylogenetic analyses emphasising South American taxa by Marvaldi et al. (2018).

Remarks. The circumscription of Eustylini has been problematic since Lacordaire (1863), in French (some as 'Cyphides' p. 107, some as 'Geonémides' p. 125 and some as 'Eustylides' p. 205). Different genera, currently placed in Eustylini, have also been grouped together with members of Phyllobiini and Naupactini through time; most genera were treated as incertae sedis in the Coleopterorum Catalogus (Lona 1938: 508-525, 530-532). Kuschel (in Wibmer and O'Brien 1986a) brought together the majority of the genera that now compose Eustylini into a single tribe; the tribe is treated as 'Eustylina' by Morrone (1999). Some additions to the tribe have been made with transfers from other tribes, justified by a morphology-based 
phylogeny presented by Franz (2012). Marvaldi et al. (2018) made the most recent addition by placing Galapagonotus Anderson \& Lanteri, 2000 (Anderson and Lanteri 2000, 3) in Eustylini; they indicate that Coconotus Anderson \& Lanteri, 2000 (Anderson and Lanteri 2000,6) might also be an eustyline, but this remains to be confirmed, as it also shares features with the geonemine genus Lachnopus Schönherr, 1840 (Schönherr 1840b, 380), particularly with species in the luctuosus species-group (see Girón et al. 2018). Recent phylogenetic analyses (Franz 2012; Zhang et al. 2017; Marvaldi et al. 2018) indicate close relationships of Eustylini with taxa currently placed in Geonemini Gistel, 1856 (Gistel 1856, 373), which is primarily Caribbean and Central American.

The generic limits between some eustyline genera are not clearly defined; this is particularly true for Compsus, Oxyderces Schönherr, 1823 (Schönherr 1823, col. 1140), Exorides and Xestogaster Marshall, 1922 (Marshall 1922b, 221), all well represented in Colombia. This highlights the pressing need for taxonomic and phylogenetic revisions in the tribe, including (ideally recent) Colombian material that is already deposited in national collections. This particular group is part of the "Compsus genus complex" (Girón and Chamorro 2020); the authors compare several species of Compsus, Oxyderces and Exophthalmus which, by their colouration, may be confused with the golden-headed weevil, Compsus auricephalus (Say, 1824) (Say 1824), which is the only species of Compsus to occur in North America.

Members of Eustylini are amongst the most commonly found entimines in Colombian biological collections; Compsus is the most frequently observed and collected genus, followed by Exorides and perhaps Eustylus. Species of Exophthalmus are rare and seem to be restricted to the Pacific Region. Species of Compsus have been recorded as Citrus pests (Cano et al. 2002a, b; Gallego et al. 2012, O'Brien and Peña 2012) in Colombia and sugar cane in Venezuela (Kuschel 1955a). The Colombian endemic Oxyderces viridipes (Boheman in Schönherr 1840b, 179) has been intercepted at ports in the USA on Hydrangea flowers (Hydrangeaceae; see Girón and Chamorro 2020). In nature, eustylines commonly rest with their prolegs extended towards the front of the body.

\section{Tribe Lordopini Schönherr, 1823}

Fig. 8

Recognition. Medium-sized weevils (approx. 10-20 mm); scale coverage variable in presence, density, pattern and colouration; iridescent scales and setae may be present; surface usually even (not coarsely sculptured); head (including rostrum, Fig. 8B, C) subrectangular to conical, usually longer than wide; eyes usually large and elongated in lateral view, weakly to moderately projecting from surface of head; frons nearly as wide as or wider than interantennal distance, often bearing median fovea; rostrum nearly parallel-sided, broadened apically (Fig. 8B) or with lateral margins apically converging (Fig. 8C); dorsal surface of rostrum either flat 


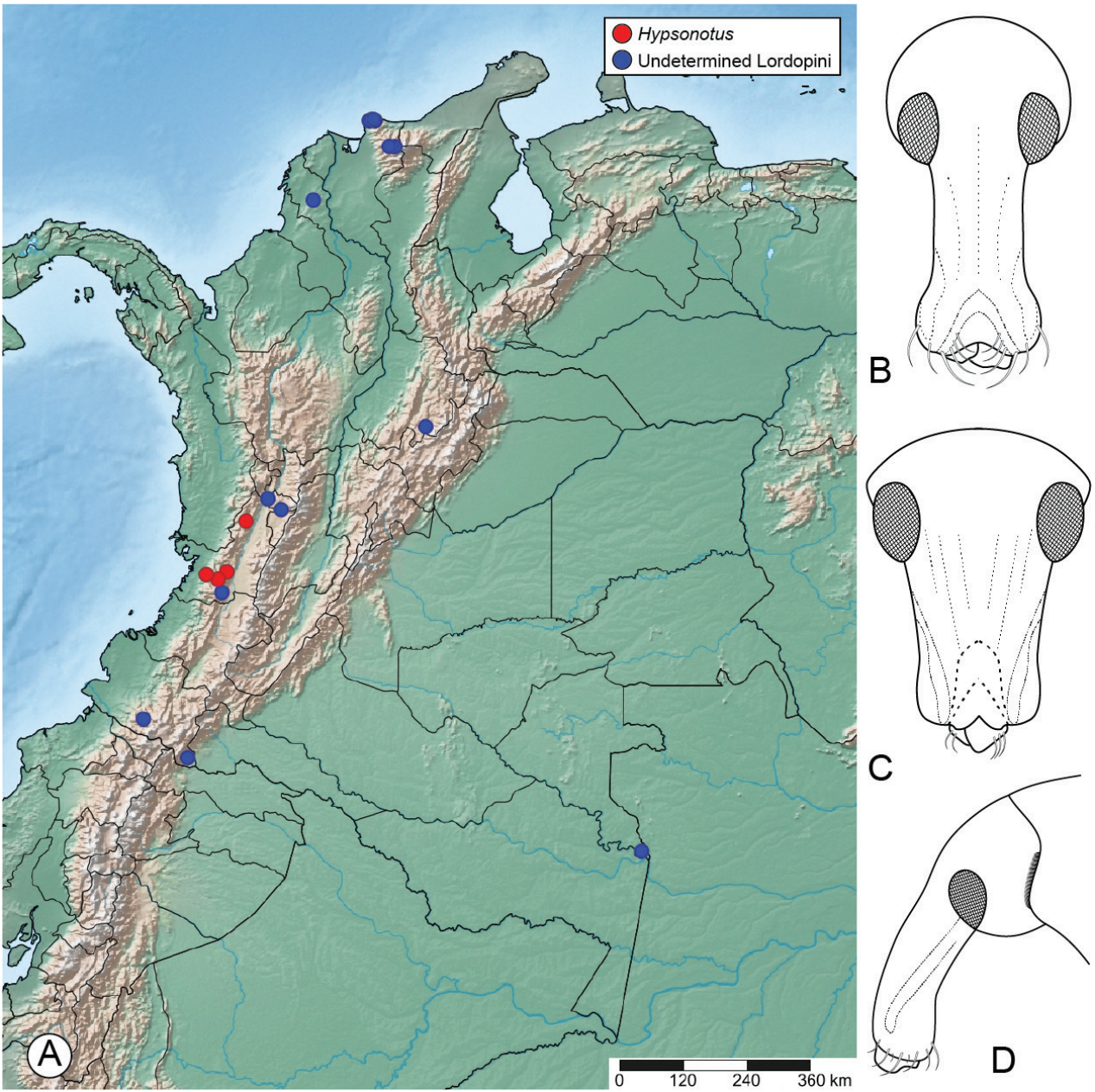

Figure 8. Distribution and some head variants of Lordopini: A distribution map of records for Hypsonotus and undetermined lordopines in Colombia B, C head in dorsal view: B Hypsonotus C Lordops D head and anterior section of prothorax in lateral view of Hypsonotus showing well-developed postocular lobe with setae forming a fringe.

or with one or three longitudinal carinae; antennal scrobe generally only visible at apical region in dorsal view; nasal plate (see Fig. 1B, C) usually well developed, flat or depressed regarding surface of rostrum; anterior margin of prothorax in lateral view strongly sinuate, forming conspicuous postocular lobe (Fig. 8D); postocular setae present, forming a fringe instead of a tuft (Fig. 8D); elytral shoulders absent to well-developed (see Fig. 1N-P); tubercles may be present on elytra; legs relatively slender.

Amongst entimines with well-developed postocular lobe, lordopines are recognisable because of their elongated rostrum (Fig. 8B, D) or their conical heads with apically-converging lateral margins of the rostrum (Fig. 8C). They may be 
confused with mid-sized Entimini, but the bulky shape of the body of most Entimini and the overall shape of the head differentiate them (compare Fig. 5B, C with Fig. 8B, C).

Diversity. There are 44 genera with 291 species of Lordopini described (Wibmer and O'Brien 1986a). Eleven genera, represented by 33 species, have been recorded from Colombia, four and 25, respectively, being endemic.

General distribution. Lordopini is a strictly Neotropical tribe, ranging from Mexico to Paraguay, including some of the Lesser Antilles. Lordopies have been recorded from the following countries: Argentina, Bolivia, Brazil, Colombia, Ecuador, French Guiana, Paraguay, Peru, Venezuela; Costa Rica, Belize, El Salvador, Guatemala, Honduras, Mexico, Nicaragua, Panama; Grenada, St. Vincent (AlonsoZarazaga and Lyal 1999). The higher diversity of this tribe is massively concentrated in Brazil.

Distribution in Colombia. Representatives of Lordopini have been recorded from Bolívar, Magdalena, Nariño, Quindío, Santander, Valle del Cauca and Vaupés (Suppl. material 2).

Bibliographic resources. A general diagnosis for Lordopini can be found in Lacordaire (1863, 260, as 'Hypsonotides', in French). Only two genera appear in the Biologia Centrali-Americana (Sharp and Champion 1911, 300, under 'Entimina'). Kessel (1932, 1935, 1937, in German) revised several genera and provided keys to genera and species, focusing on Brazilian fauna, but these volumes are not yet available online and are rather difficult to find in libraries.

Remarks. Lordopini is one of the least-studied entimine tribes in the region and needs systematic revision: 18 genera are Brazilian endemics; more than one third of the species belong to Hypsonotus Germar, 1824 (Germar 1824, 367, 115 spp.) and one fifth belongs to the genus Lordops Schönherr, 1823 (Schönherr 1823, col. 1142, 59 spp.). From the remaining genera, 17 are monotypic and 11 are represented by only two species. All of these facts might indicate problems with current generic definitions. Furthermore, there are no phylogenetic analyses, including lordopines, to date. There are records of an undetermined species of Hypsonotus attacking peanuts in Brazil (Araujo et al. 1977); other than that, the natural history of the Lordopini remains largely unknown.

\section{Tribe Naupactini Gistel, 1856}

Fig. 9

Recognition. Small to medium weevils (approx. 3.5-35 mm); scale coverage highly variable in presence, density and colouration; iridescent scales, erect setae or waxy secretions are frequently present; surface usually even; head (including rostrum; Fig. 9C-F) subrectangular to trapezoid, nearly as long or shorter than wide; eyes rounded to oval in lateral view, small to large, laterally positioned and moderately to strongly projected from surface of head; frons usually as wide as or wider than interantennal distance, often bearing median longitudinal furrow extending through 
rostrum; rostrum with lateral margins usually apically converging or nearly parallelsided, sometimes slightly broadened apically (Fig. 9C-F); dorsal surface of rostrum usually flat (excepting median furrow; broadly anteriorly depressed in Platyomus Sahlberg, 1823 (Sahlberg 1823, 29) and relatives, for example, Fig. 9F); antennal scrobe generally not broadly visible in dorsal view; nasal plate (see Fig. 1B, C) of variable development, usually flat to depressed regarding surface of rostrum; anterior margin of prothorax in lateral view straight, never forming postocular lobe; postocular setae absent; elytral shoulders absent to well-developed (see Fig. 1N-P); tubercles may be present on elytra; profemora sometimes enlarged (see Fig. 1J); apical region of metatibia rectangular, fringed by spines along ventral and posterior margins (Fig. 1M).

Naupactines are relatively easy to recognise amongst South American entimines by the overall shape of their head, the usual presence of a median longitudinal furrow along the head and rostrum and the characteristic apex of their metatibia. They may be confused with similarly-coloured Eustylini, but the overall shape of the head (compare Fig. 7C-F with Fig. 9C-F) and the apex of the metatibia differentiate them (compare Fig. 7C-F with Fig. 9C-F). Small naupactines may be confused with anypotactines, from which they can be differentiated by the metatibial apex. From Tanymecini, naupactines can be distinguished by the lack of postocular setae in Naupactini and the shape of the metatibial apex.

Diversity. Naupactini contains 67 genera with over 500 species described (Lanteri and del Río 2016a). Fourteen genera, represented by 36 species have been recorded from Colombia, two genera and 22 species being endemic.

General distribution. In the New World, Naupactini ranges from the USA to Argentina and Chile, including some of the Caribbean islands. Naupactines have been recorded from the following countries: Argentina, Bolivia, Brazil, Chile (including Isla de Pascua, Juan Fernández Is.), Colombia, Ecuador (including Galapagos Is.), French Guiana, Guyana, Paraguay, Peru, Uruguay, Surinam, Trinidad, Venezuela; Belize, Costa Rica, El Salvador, Guatemala, Honduras, Mexico, Nicaragua, Panama; USA (Alonso-Zarazaga and Lyal 1999). Its highest diversity is concentrated in Argentina, Bolivia, Brazil, Paraguay and Uruguay, which coincides with areas where they have been extensively studied.

Distribution in Colombia. Representatives of the tribe have been recorded from 18 Departments: Antioquia, Bolívar, Boyacá, Caldas, Casanare, Cauca, Cesar, Chocó, Cundinamarca, Guaviare, Magdalena, Meta, Nariño, Quindío, Risaralda, Valle del Cauca, Vaupés and Vichada (Suppl. material 2).

Bibliographic resources. A recent summary of the status of knowledge in Naupactini can be found in Lanteri and del Río (2016a). Several genera of Naupactini have been revised or described since the 1980s (Lanteri 1980, 1982, 1984, 1985, 1986, 1989, 1990a, b, c, d, 1992, 1995; Lanteri and Loiácono 1990; Lanteri and O'Brien 1990; Bordón 1991, 1997; Lanteri and Morrone 1991, 1995; Lanteri and Díaz 1994; Lanteri and Marvaldi 1995; Lanteri and del Río 2003, 2004, 2005 , 2006a, a, 2016b; del Río et al. 2006, 2012; del Río and Lanteri 2007a, b, 2011a, b, 

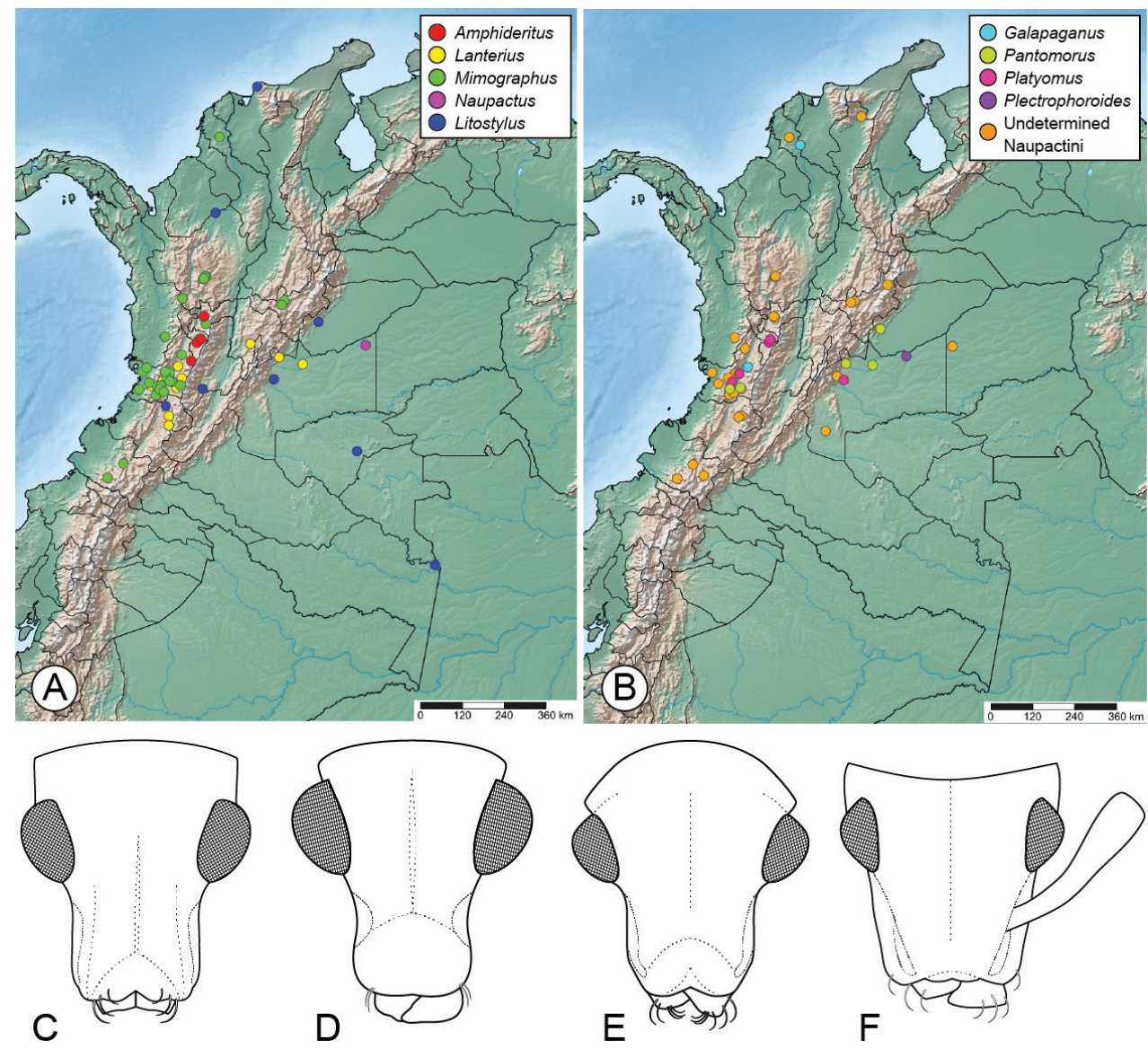

Figure 9. Distribution and some head variants of Naupactini: A, B distribution maps of Naupactini in Colombia: A records for Amphideritus, Lanterius, Mimographus and Naupactus B records for Litostylus, Platyomus and undetermined naupactines C-F head in dorsal view: C Mimographus D undetermined Naupactini E Litostylus F "Platyomus" (see discussion under Naupactini) with characteristic broad and flattened antennal scape.

2012, 2013, 2019, 2020; Lanteri et al. 2017). There have also been recent efforts to elucidate the phylogenetic relationships amongst naupactine genera (Lanteri and del Río 2016a; del Río et al. 2018) and with other entimines (Marvaldi et al. 2018). Keys to genera can be found in Sharp and Champion $(1911,221)$ and van Emden (van Emden 1944b); a key to Andean genera is available in del Río and Lanteri (2011a).

Remarks. Naupactini is the largest tribe of New World entimines and one of the best known, mainly because of the revisionary and phylogenetic efforts of Dr. Analía Lanteri, Dr. Adriana Marvaldi, Dr. Guadalupe del Río and collaborators, based in Argentina. Different naupactine clades are specific to certain biogeographic regions in South America (see Lanteri 1992; del Río and Lanteri 2011a), with flightlessness 
and parthenogenesis being frequent in certain systems (Lanteri and Normark 1995; Guzmán et al. 2012; Lanteri et al. 2013; Lanteri and del Río 2016a). A detailed study of the female genitalia and oviposition habits in Naupactini, in a phylogenetic context, can be found in Lanteri and del Río (2008).

Most revisionary efforts to date have focused on fauna from Argentina, Brazil and surrounding countries. In northern South America, naupactines from Venezuela were studied by Bordón [1991, genus Macrostylus Boheman, 1840 (Schönherr 1840a, 921), 26 spp. described as new; 1997, genus Naupactus Dejean, 1821 (Dejean 1821, 94), 24 spp. described as new]; none of these species has been recorded from Colombia to date. Other than that, the naupactine fauna from northern South America, Central America and the Caribbean is still in need of revision.

Several naupactine species are economically important (e.g. Lanteri et al. 2002, 2013); Leschenius vulcanorum (Kirsch, 1889) (Kirsch 1889, 17) has been recorded in Colombia as the 'Potato shooter' or 'tiroteador de la papa' (Canchala 1992; Peña 2001; Cortázar Gómez et al. 2012).

Members of Naupactini are very common in Colombian entomological collections, especially the genera Lanterius Alonso-Zarazaga \& Lyal, 1999 (AlonsoZarazaga and Lyal 1999, 164), Mimographus Schönherr, 1847 (Schönherr 1847, 34) and allies. Platyomus was recorded for the first time for Colombia by Girón (2007a; for Risaralda and Valle del Cauca) and then by Cardona-Duque et al. (2018; for Antioquia); these records might be erroneously identified and, instead, the specimens cited could be representatives of Chamaelops Kirsch, 1868 (Kirsch 1868, 235), which is fairly closely related to Platyomus (Lanteri and del Río 2016a); Chamaelops has previously been recorded for Colombia, considered endemic and includes two described species. Galapaganus Lanteri, 1992 (Lanteri 1992, 230) and Pantomorus Schönherr, 1840 (Schönherr 1840a, 942) were also recorded by Girón (2007a; both from Valle del Cauca) and are presented here (see Suppl. material 2; including records from Bolívar for Galapaganus and from Casanare and Meta for Pantomorus), but these records need to be confirmed.

Lanterius was erected by Alonso-Zarazaga and Lyal $(1999,164)$ to group species that were previously placed in a misidentified concept of Mimographus Schönherr, 1847 (Schönherr 1847, 34; see del Río and Lanteri 2018, 331). Even though del Río and Lanteri (2018) indicate that each of the Mimographus species, listed by Wibmer and O'Brien $(1986 a, 56)$, needs to be studied in detail in order to determine their appropriate placement, the Colombian species are here listed as new combinations under Lanterius in an attempt to prevent confusion, as there are species of true Mimographus recorded from Colombia as well. These new combinations are: Lanterius ardosiacus (Kirsch, 1868: 229), comb. nov., Lanterius cinereoguttatus (Champion, 1911: 228), comb. nov., Lanterius hirtus (Voss, 1953: 60), comb. nov., Lanterius laesicollis (Schönherr, 1847: 35), comb. nov., Lanterius micans (Kirsch, 1868: 229), comb. nov., Lanterius rotundicollis (Kirsch, 1889: 15), comb. nov., Lanterius versicolor (Kirsch, 1889: 15), comb. nov., and Lanterius vittatus (Kirsch, 1889: 14), comb. nov. 


\section{Tribe Premnotrypini Kuschel, 1956}

Fig. 10D

Recognition. Small weevils (approx. 4-15 mm); scale coverage usually dense, uniform, and brown, often with patches of erect scales or setae; surface from even to undulate or tuberculate; head (including rostrum, Fig. 10D) usually conical and longer than wide; eyes laterally positioned and weakly to moderately projected from surface of head; frons wider than interantennal distance; rostrum elongate, usually with lateral margins apically converging, sometimes slightly broadened apically; dorsal surface of rostrum flat to undulate; mandibular scar reduced to absent; antennal scrobe generally not broadly visible in dorsal view; nasal plate (see Fig. 1B, C) of variable development, usually flat to elevated regarding surface of rostrum; anterior margin of prothorax in lateral view sinuate, forming well-developed and large postocular lobe (see Fig. 1F); postocular setae forming fringe; elytral shoulders usually well-developed (see Fig. 1P); tubercles may be present on elytra.

Premnotrypines may not be easily recognisable as entimines, as their rostrum is relatively slender and usually directed towards the body when mounted; the reduction or absence of mandibular scars would make them pass as other miscellaneous Curculionidae. Amongst entimines, they can be recognised by their small size and well-developed postocular lobe, fringed by postocular setae. By their size, premnotrypines can be confused with anypotactines or small tanymecines, but can be recognised by the presence of a well-developed postocular lobe, lacking in both Anypotactini and Tanymecini.

Diversity. There are only three genera in Premnotrypini with 28 species (Kuschel 1956; Wibmer and O'Brien 1986a, 88). There is only one species recorded from Colombia.

General distribution. Premnotrypini is an exclusively Andean group, distributed from Colombia to Bolivia and northern Chile. Their diversity is concentrated in Bolivia and Peru, at elevations over $3000 \mathrm{~m}$ a.s.l. No specimens of this tribe were identified in the collections revised for this work.

Bibliographic resources. The tribal diagnosis, key to genera, descriptions of two of the genera and keys to all species can be found in Kuschel (1956, in Spanish).

Remarks. The genus Premnotrypes is associated with potato cultivars and contains economically-important species commonly known as the "Andean potato weevils" (see Alcázar and Cisneros 1998). There are many studies in the natural history and control of pest species (e.g. Alcalá and Alcázar 1976; Calvache 1987; Dueñas 1989), but no phylogenetic studies in Premnotrypini have been published to date.

\section{Tribe Tanymecini Lacordaire, 1863}

Fig. 10A-C

Recognition. Small to large weevils (approx. 4-20 mm); scale coverage variable in presence, density and colouration, often dense and uniform, with colouration 
patterns formed by scales on dorsal surface; surface usually even, sometimes granulate; head (including rostrum; Fig. 10B, C) usually subrectangular and nearly as long as wide; eyes laterally positioned and weakly to strongly projected from surface of head; frons usually as wide as interantennal distance, bearing median fovea or small (narrow and short) longitudinal furrow that may extend along rostrum; rostrum subquadrate, usually with lateral margins parallel, sometimes slightly constricted basad of antennal insertion; dorsal surface of rostrum flat to slightly depressed; antennal scrobe only visible along anterior section in dorsal view; epistoma usually well-developed; nasal plate (see Fig. 1B, C) of variable development, flat to depressed regarding surface of rostrum; anterior margin of prothorax in lateral view straight (Fig. 1D), never forming well-developed postocular lobe; postocular setae usually present, clearly visible, grouped as a tuft, usually positioned near ventral margin of prothorax (Fig. 1D); elytral shoulders absent to well-developed (see Fig. $1 \mathrm{~N}-\mathrm{P}$ ); tubercles may be present on elytra and elytral apices may be projected; profemora frequently enlarged (see Fig. 1J).

Amongst Neotropical entimines, members of Tanymecini are easily recognisable by the presence of postocular setae, although not all tanymecines have this feature and not all the species with postocular setae are tanymecines. The postocular setae in Tanymecini are usually clustered, forming a tuft as opposed to distributed along the margin forming a fringe (compare Fig. 1D with Fig. 1F). Some tanymecines can be potentially confused with Naupactini because of their flat frons, median furrow and laterally-positioned eyes, but the presence of postocular setae in Tanymecini sets them apart easily; they can also be differentiated by the particular shape of the apex of the metatibia in Naupactini, which is rectangular and fringed by spines along the ventral and posterior margins (Fig. 1M; compare with rounded margins in tanymecines, Fig. 1L).

Diversity. There are about 100 genera of Tanymecini distributed worldwide. Eighteen genera are represented throughout the Americas by 325 species (O'Brien and Wibmer 1982, 45; Wibmer and O'Brien 1986a, 67; Alonso-Zarazaga and Lyal 1999, 178; Morrone 1999, 143; Cortés-Hernández and Anderson 2019; CortésHernández and Morrone 2020). There are 58 species of Tanymecini recorded from Colombia, 29 of them being considered endemic.

General distribution. Tanymecines are distributed throughout the Americas and the Caribbean islands, including the following countries: Argentina, Bolivia, Brazil, Chile, Colombia, Ecuador, Peru, Paraguay, Uruguay, Venezuela; Belize, Costa Rica, El Salvador, Guatemala, Honduras, Mexico, Nicaragua, Panama; Bahamas, Cuba, Dominica, Dominican Republic, Grand Cayman, Grenada, Guadeloupe, Haiti, Jamaica, Saint Vincent; C, E Canada, USA (Alonso-Zarazaga and Lyal 1999). Their highest diversity is concentrated in Central America and northern South America.

Distribution in Colombia. Tanymecines have been found in collections from Antioquia, Bolívar, Boyacá, Caldas, Cauca, Cundinamarca, Magdalena, Meta, Nariño, Norte de Santander, Quindío, Risaralda and Valle del Cauca (Suppl. material 2). 


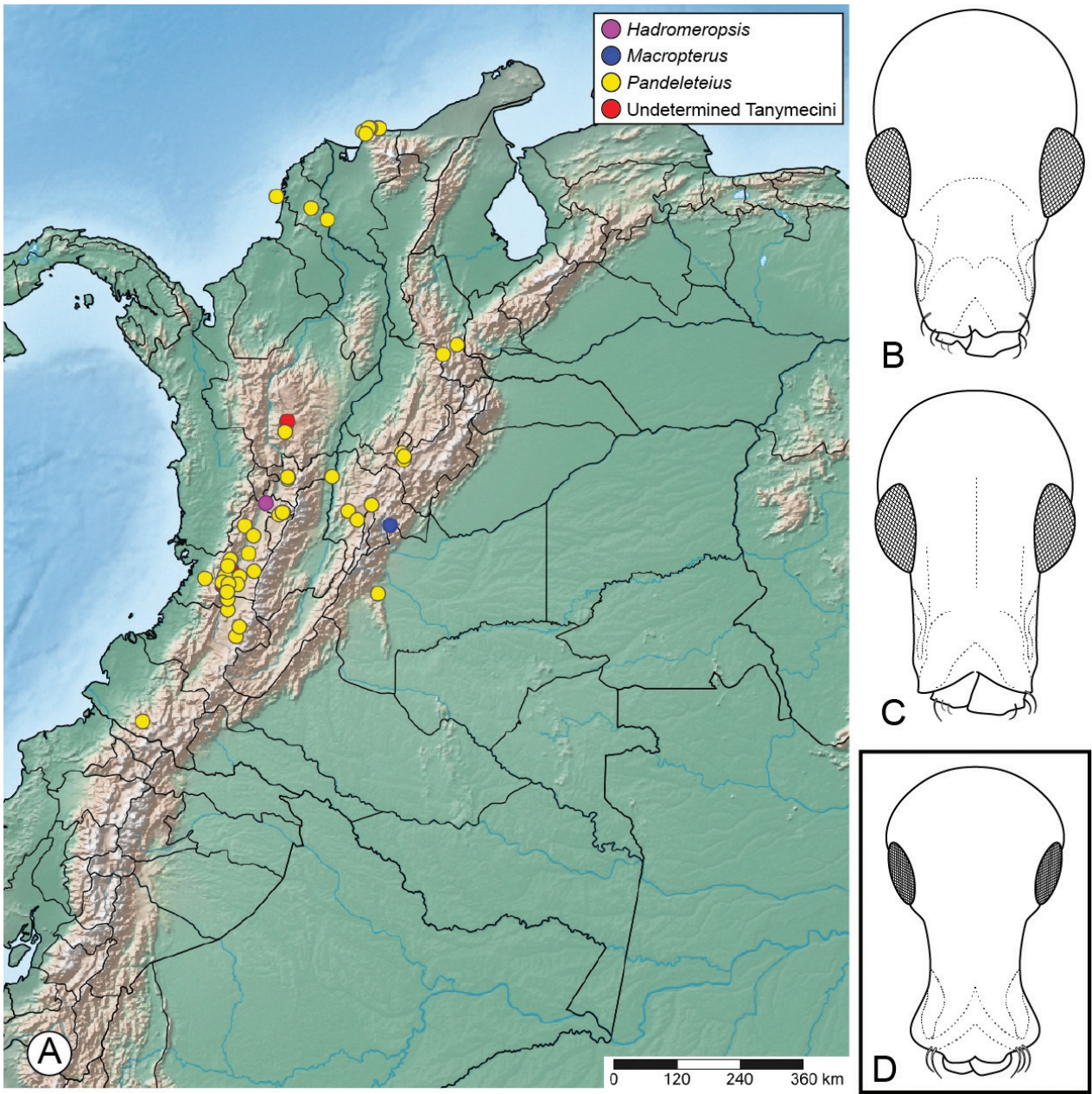

Figure 10. Distribution and some head variants of Tanymecini and Premnotrypini: A distribution map of records for Hadromeropsis, Macropterus, Pandeleteius and undetermined tanymecines in Colombia B, C head in dorsal view of Tanymecini: B Pandeleteius $\mathbf{C}$ Hadromeropsis $\mathbf{D}$ head in dorsal view of Premnotrypes (Premnotrypini).

Bibliographic resources. Most genera of Tanymecini represented in the Americas were revised by Anne Howden (1959, 1961, 1963, 1966, 1969, 1970, 1974, 1976, 1982, 1986, 1993, 1996, 1998, 2001, 2004, 2008, 2011; Girón and Howden 2019). A key to genera recorded from Mexico was published by Cortés-Hernández and Morrone (2019), which includes most genera represented in Colombia. Howden's revision of the species of Pandeleteius of Colombia and Venezuela (Howden 1976) considerably increased the number of species known from Colombia and includes a key to species. 


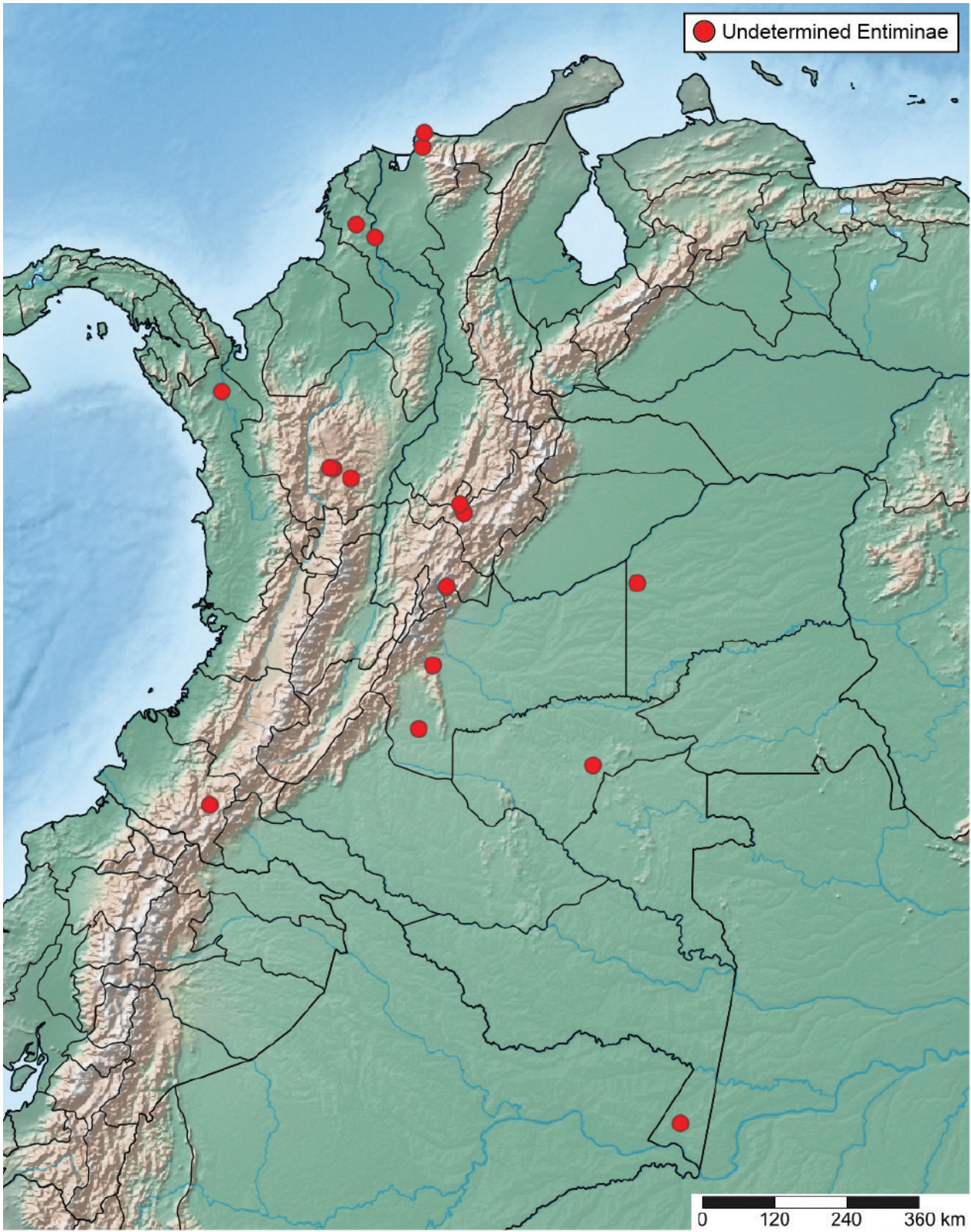

Figure 11. Distribution of undetermined entimines in Colombia.

Remarks. Tanymecini is one of the best-known tribes of entimines of the Americas, thanks to the works of Anne Howden. Tanymecines, especially Pandeleteius, are quite common in Colombia. In nature, tanymecines are commonly seen with their prolegs resting perpendicular to the body axis, a type of behaviour shared with some naupactines. 


\section{List of valid species of Entiminae recorded from Colombia}

Genera and species in bold letters indicate endemic taxa. Fossil taxa are indicated by $(+)$. Localities in bold letters indicate type locality. Localities marked with an asterisk are records taken from ASUCOB. A double asterisk means that identitications need to be corroborated. A question mark (?) in the distribution indicates that the locality record is doubtful and needs confirmation. Type localities from countries other than Colombia are omitted. Taxon names include author, year and page number of the original description (e.g. Anypotactus Schönherr 1840b, 299); for some of Schönherr's taxa, the page number corresponds to a column number in the publication and is indicated by 'col'. (e.g. Entiminae Schönherr 1823, col. 1138). See other locality remarks in the methods section.

\section{Tribe Anypotactini Champion, 1911: 215}

Genus Anypotactus Schönherr, 1840: 299

Distribution: Bolivia, Colombia, Peru, Venezuela; Costa Rica, El Salvador, Guatemala, Honduras, Nicaragua, Panama.

References: Schönherr 1840b, 299; Sharp and Champion 1911, 215, 174; Kuschel 1955b, 275, O'Brien and Wibmer 1982, 29; Wibmer and O'Brien 1986a, 44; AlonsoZarazaga and Lyal 1999, 145; Morrone 1999, 135.

Anypotactus exilis Boheman, 1840: 300

Distribution: Colombia, Venezuela; Costa Rica, Guatemala, Honduras, Nicaragua, Panama.

References: Boheman in Schönherr 1840b, 300; Sharp and Champion 1911, 216, O’Brien and Wibmer 1982, 29; Wibmer and O'Brien 1986a, 44; Morrone 1999, 135.

Anypotactus morosus (Boheman, 1840: 449)

Distribution: Colombia.

References: As Polydrosus morosus by Boheman in Schönherr 1840b, 449; Kuschel 1955b, 277 (as Anisactus morosus), Kuschel in Wibmer and O'Brien 1986a, 44; Morrone 1999, 135.

Genus Bothinodontes Kirsch, 1868: 241

Distribution: Colombia (Caldas, Tolima); Mexico (?). 
References: Kirsch 1868, 241; Gemmiger and von Harold 1871, 2242; Sharp and Champion 1911, 331, O’Brien and Wibmer 1982, 29; Wibmer and O'Brien 1986a, 45; Alonso-Zarazaga and Lyal 1999, 145; Morrone 1999, 135.

Bothinodontes gibbipennis (Champion, 1911: 332)

Distribution: Colombia; Mexico (?).

References: As Bothynodontes by Champion in Sharp and Champion 1911, 332, O’Brien and Wibmer 1982, 29; Wibmer and O’Brien 1986a, 45; Morrone 1999, 135.

\section{Bothinodontes squalidus Kirsch, 1868: 243}

Distribution: Colombia ('Bogotá').

References: Kirsch 1868, 243; Wibmer and O’Brien 1986a, 45; Morrone 1999, 135.

Genus Cylloproctus Faust, 1892: 22

Distribution: Brazil, Colombia, Venezuela.

References: Faust 1892, 22; Wibmer and O’Brien 1986a, 45; Alonso-Zarazaga and Lyal 1999, 145; Morrone 1999, 135.

\section{Cylloproctus modestus Faust, 1892: 23}

Distribution: Colombia [Columbia].

References: Faust 1892, 23 (in footnote), Wibmer and O'Brien 1986a, 45; Morrone 1999, 135.

\section{Cylloproctus pantomoroides Voss, 1936: 109}

Distribution: Colombia (Cundinamarca: Fusagasugá).

References: Voss 1936, 109; Wibmer and O’Brien 1986a, 45; Morrone 1999, 135.

Genus Hypsometopus Kirsch, 1868: 222

Distribution: Colombia.

References: Kirsch 1868, 222; Wibmer and O’Brien 1986a, 45; Alonso-Zarazaga and Lyal 1999, 146; Morrone 1999, 136. 
Hypsometopus inquinatus Kirsch, 1868: 223

Distribution: Colombia ('Bogotá').

References: Kirsch 1868, 223; Wibmer and O’Brien 1986a, 45; Morrone 1999, 136.

Genus Phanasora Pascoe, 1881: 38

Distribution: Colombia, Ecuador.

References: Pascoe 1881, 38; Wibmer and O'Brien 1986a, 45; Alonso-Zarazaga and Lyal 1999, 146; Morrone 1999, 137.

\section{Phanasora plumbea Pascoe, 1881: 39}

Distribution: Colombia ('Bogotá').

References: Pascoe 1881, 39; Wibmer and O’Brien 1986a, 45; Morrone 1999, 137.

Genus Polydacrys Schönherr, 1834: 130

Distribution: Bolivia, Colombia, Cuba, Dominica, Granada, Guadeloupe, Puerto Rico, Saint Vincent; Belize, Costa Rica, El Salvador, Guatemala, Honduras, Mexico, Nicaragua, Panama; SW USA (Texas).

References: Schönherr 1834, 130; Sharp and Champion 1911, 217, O’Brien and Wibmer 1982, 29; Wibmer and O’Brien 1986a, 44; Alonso-Zarazaga and Lyal 1999, 146; Morrone 1999, 137.

Polydacrys seriegranosus Champion, 1911: 218

Distribution: Bolivia, Colombia; Panama.

References: Sharp and Champion 1911, 218, O'Brien and Wibmer 1982, 29; Wibmer and O’Brien 1986a, 44; Morrone 1999, 137.

Genus Prepodellus Kirsch, 1868: 239

Distribution: Colombia; Costa Rica, Mexico, Nicaragua, Panama.

References: Kirsch 1868, 239, O’Brien and Wibmer 1982, 29; Wibmer and O’Brien 1986a, 44; Alonso-Zarazaga and Lyal 1999, 146; Morrone 1999, 137. 
Prepodellus nigriclavis Kirsch, 1868: 240

Distribution: Colombia ('Bogotá', Cundinamarca (La Vega $\left.{ }^{\star}\right)$ ).

References: Kirsch 1868, 240; Wibmer and O’Brien 1986a, 44; Morrone 1999, 137.

Prepodellus ruficornis Kirsch, 1868: 240

Distribution: Colombia ('Bogotá', Cundinamarca (Mosquera*)).

References: Kirsch 1868, 240; Wibmer and O’Brien 1986a, 44; Morrone 1999, 137.

Tribe Entimini Schönherr, 1823: col. 1138

Genus Cydianerus Schönherr, 1840: 737

Distribution: Argentina, Bolivia, Brazil, Colombia, Paraguay, Venezuela; Costa Rica, El Salvador, Honduras, Mexico, Panama.

References: Schönherr 1840a, 737; Sharp and Champion 1911, 300 as Entimina, O'Brien and Wibmer 1982, 67; Wibmer and O'Brien 1986a, 101; Alonso-Zarazaga and Lyal 1999, 144; Morrone 1999, 110; Poinar et al. 2017 (key to species).

Cydianerus eukrinus Poinar, Bukejs \& Legalov, 2017: 88 (+)

Distribution: Colombia (Santander, copal resin).

References: Poinar et al. 2017, 88.

Cydianerus pascoei (Bovie, 1908a: 4)

Distribution: Colombia; Panama.

References: Bovie 1908a, 4 as Polydius, in footnote, O'Brien and Wibmer 1982, 67; Wibmer and O'Brien 1986a, 101; Morrone 1999, 111.

Genus Entimus Germar, 1817: 341

Distribution: Argentina, Bolivia, Brazil, Colombia, Ecuador, French, Guiana, Guyana, Paraguay, Peru, Uruguay; Costa Rica, Nicaragua, Panama.

References: Germar 1817, 341; Sharp and Champion 1911, 301, O'Brien and Wibmer 1982, 67; Wibmer and O’Brien 1986a, 99; Alonso-Zarazaga and Lyal 1999, 144; Morrone 1999, 111, 2002; Morrone et al. 2019. 
Entimus arrogans Pascoe 1872: 448

Distribution: Colombia; Costa Rica, Nicaragua, Panama.

References: Pascoe 1872, 448; Sharp and Champion 1911, 301, O'Brien and Wibmer 1982, 67; Wibmer and O'Brien 1986a, 100; Morrone 1999, 111, 2002, 505.

Entimus granulatus (Linnaeus, 1758: 386)

Distribution: Bolivia, Brazil, Colombia, Ecuador, French Guiana, Guyana, Peru; Panama. References: Linnaeus 1758, 386 (as Curculio granulatus), O'Brien and Wibmer 1982, 67; Wibmer and O’Brien 1986a, 100; Morrone 1999, 111, 2002, 507.

Genus Rhigus Schönherr, 1823: col. 1138

Distribution: Argentina, Brazil, Colombia, French Guiana, Paraguay, Peru.

References: Schönherr 1823, col. 1138; Wibmer and O'Brien 1986a, 101; Alonso-Zarazaga and Lyal 1999, 145; Morrone 1999, 121; Gaiger 2001.

Rhigus speciosus (Linnaeus, 1758: 385)

Distribution: Brazil, Colombia (Amazonas, Tolima), French Guiana, Peru.

References: Linnaeus 1758, 385 (as Curculio speciosus), Wibmer and O'Brien 1986a, 102; Morrone 1999, 121; Gaiger 2001, 63; Girón and Cardona-Duque 2018, 181 (first record for Colombia), Gillett and Barr 2020 (first record for Peru).

Tribe Eudiagogini LeConte, 1874: 454

Genus Colecerus Schönherr, 1840: 927

Distribution: Colombia; Costa Rica, El Salvador, Guatemala, Honduras, Mexico, Nicaragua; SW USA.

References: Schönherr 1840a, 927; Sharp and Champion 1911, 305, O’Brien and Wibmer 1982, 58 (under Promecopini), Wibmer and O'Brien 1986a, 81 (under Promecopini), Alonso-Zarazaga and Lyal 1999, 157; Morrone 1999, 110 (under Entimina).

\section{Colecerus albidus (Chevrolat, 1881: XXXVIII)}

Distribution: Colombia ('Bogotá'). 
References: Chevrolat 1881, XXXIII, Wibmer and O’Brien 1986a, 81; Morrone 1999, 110.

Genus Promecops Sahlberg, 1823: 30

Distribution: Argentina, Bolivia, Brazil, Colombia, Ecuador, French Guiana, Guyana, Paraguay, Peru, Venezuela; Belize, Costa Rica, El Salvador, Guatemala, Honduras, Mexico, Nicaragua, Panama; Grenadines, Guadeloupe, St. Vincent.

References: Sahlberg 1823, 30, O’Brien and Wibmer 1982, 59 (under Promecopini), Wibmer and O’Brien 1986a, 82 (under Promecopini), Alonso-Zarazaga and Lyal 1999, 157; Morrone 1999, 119 (under Entimina).

\section{Promecops lepidoides Voss, 1934: 75}

Distribution: Colombia (Meta: Villavicencio).

References: Voss 1934, 75 (in key), Wibmer and O’Brien 1986a, 83; Morrone 1999, 120.

\section{Promecops lepidus Fåhraeus, 1840: 317}

Distribution: Colombia, [Orinoco] (Magdalena (Ciénaga)*).

References: Chevrolat 1881, XXXIII, Wibmer and O’Brien 1986a, 81; Morrone 1999, 110.

Promecops leucothyreus Fåhraeus, 1840: 328

Distribution: Bolivia, Colombia ('Bogotá', Antioquia (Puerto Berrío), Bolívar (Cartagena)*, Magdalena); Guatemala, Honduras, Mexico, Nicaragua.

References: Fåhraeus in Schönherr 1840b, 328; Voss 1934, 80 (in key, as Promecops leucothyrea), O'Brien and Wibmer 1982, 59; Wibmer and O'Brien 1986a, 83; Morrone 1999, 120.

\section{Promecops rhombicus Fåhraeus, 1840: 326}

Distribution: Colombia [Columbia].

References: Fåhraeus in Schönherr 1840b, 326; Voss 1934, 97 (listed as Promecops rhombica), Wibmer and O’Brien 1986a, 83; Morrone 1999, 120. 
Promecops rhombifer Fåhraeus, 1840: 325

Distribution: Colombia, Guyana, Venezuela.

References: Fåhraeus in Schönherr 1840b, 325; Voss 1934, 90 (in key, as Promecops rhombifera), Wibmer and O’Brien 1986a, 83; Morrone 1999, 120.

\section{Tribe Eustylini Lacordaire, 1863: 205}

Genus Brachyomus Lacordaire, 1863: 130

Distribution: Colombia, Ecuador, French Guiana, Peru, Trinidad, Venezuela; St. Vincent. References: Lacordaire 1863, 130; Wibmer and O'Brien 1986a, 73, 1986b; Alonso-Zarazaga and Lyal 1999, 158; Morrone 1999, 123.

Brachyomus quadrinodosus (Boheman, 1842: 217)

Distribution: Colombia, Venezuela.

References: Boheman in Schönherr 1842, 217 (as Geonemus), Wibmer and O’Brien 1986a, 74; Morrone 1999, 123.

\section{Brachyomus quadrituberculatus (Boheman, 1842: 216)}

Distribution: Colombia.

References: Boheman in Schönherr 1842, 216 (as Geonemus), Wibmer and O’Brien 1986a, 74; Morrone 1999, 123.

Genus Compsus Schönherr, 1823: col. 1140

Distribution: Argentina, Bolivia, Brazil, Colombia, Ecuador, French Guiana, Guyana, Peru, Surinam, Venezuela; Costa Rica, Guatemala, Mexico, Nicaragua, Panama; Guadeloupe, Jamaica; NC, SE, SW USA.

References: Schönherr 1823, col. 1140; Hustache 1938a, O'Brien and Wibmer 1982, 54 (under Phyllobiini), Wibmer and O’Brien 1986a, 74; Alonso-Zarazaga and Lyal 1999, 158; Morrone 1999, 123, O’Brien and Peña 2012.

Compsus adonis Marshall, 1922: 197

Distribution: Colombia (Antioquia: Medellín). 
References: Marshall 1922b, 197; Hustache 1938a, 71 (in key, as Compsus bellus, but see discussion in Girón and Chamorro 2020, 38), Wibmer and O’Brien 1986a, 74; Morrone 1999, 123, O’Brien and Peña 2012.

Compsus aeruginosus (Boheman, 1840: 177)

Distribution: Colombia (Antioquia).

References: Boheman in Schönherr 1840b, 177 (as Platyomus aeruginosus), Wibmer and O’Brien 1986a, 74; Morrone 1999, 123.

Compsus affinis Hustache, 1938: 77

Distribution: Colombia (Meta: Villavicencio).

References: Hustache 1938a, 77; Wibmer and O’Brien 1986a, 74; Morrone 1999, 123, O’Brien and Peña 2012, 4 (in key).

Compsus albosetosus Hustache, 1938: 84

Distribution: Colombia (Cundinamarca: Bogotá).

References: Hustache 1938a, 84; Wibmer and O’Brien 1986a, 74; Morrone 1999, 124, O’Brien and Peña 2012, 5 (in key).

Compsus albus Hustache, 1938: 76

Distribution: Colombia (Cundinamarca: Fusagasugá; Tolima: Ibagué).

References: Hustache 1938a, 76; Wibmer and O’Brien 1986a, 74; Morrone 1999, 124, O’Brien and Peña 2012, 4 (in key), Girón and Chamorro 2020, 39.

Compsus alternevittatus Hustache, 1938: 83

Distribution: Colombia (Rio Chili, Boyacá (Muzo), Pensilvania (Caldas (?), Cundinamarca (?))).

References: Hustache 1938a, 83; Wibmer and O’Brien 1986a, 74; Morrone 1999, 124, O’Brien and Peña 2012, 5 (in key).

Compsus ater Kirsch, 1889: 20

Distribution: Colombia (Pasto, Santa Lucía). 
References: Kirsch 1889, 20; Wibmer and O’Brien 1986a, 74; Morrone 1999, 124.

Compsus attenuatus Hustache, 1938: 84

Distribution: Colombia (Rio Chili; Boyacá: Muzo; Quindío Tolima: Ibagué).

References: Hustache 1938a, 84; Wibmer and O’Brien 1986a, 74; Morrone 1999, 124, O’Brien and Peña 2012, 5 (in key).

Compsus bicarinatus Kirsch, 1889: 22

Distribution: Colombia (Popayan: Silvia (?)).

References: Kirsch 1889, 22; Wibmer and O’Brien 1986a, 74; Morrone 1999, 124.

Compsus bituberculatus Kirsch, 1889: 19

Distribution: Colombia (Cauca [Popayan]: Puracé).

References: Kirsch 1889, 19; Wibmer and O’Brien 1986a, 74; Morrone 1999, 124.

Compsus bituberosus Kirsch, 1868: 237

Distribution: Colombia ('Bogotá').

References: Kirsch 1868, 237; Wibmer and O’Brien 1986a, 74; Morrone 1999, 124.

Compsus candidus Hustache, 1938: 75

Distribution: Colombia ('Bogotá'); Valle del Cauca: Cartago, Palmira).

References: Hustache 1938a, 75; Wibmer and O’Brien 1986a, 74; Morrone 1999, 124, O’Brien and Peña 2012, 4 (in key).

Compsus canescens (Boheman, 1840: 181)

Distribution: Colombia; Napo and Amazon rivers (Brazil (?), Ecuador (?), Peru (?)).

References: Boheman in Schönherr 1840b, 181 as Platyomus canescens, GuérinMéneville 1855, 592 (listed), Wibmer and O’Brien 1986a, 75; Morrone 1999, 124. 
Compsus cyanitarsis Hustache, 1938: 93

Distribution: Bolivia, Colombia.

References: Hustache 1938a, 93; Wibmer and O’Brien 1986a, 75; Morrone 1999, 124, O’Brien and Peña 2012, 6 (in key).

Compsus cyphoides Hustache, 1938: 108

Distribution: Colombia (Meta: Villavicencio).

References: Hustache 1938a, 108; Wibmer and O'Brien 1986a, 75; Morrone 1999, 124, O’Brien and Peña 2012, 6 (in key).

\section{Compsus delicatulus Hustache, 1938: 79}

Distribution: Colombia (Valle del Cauca: Cartago).

References: Hustache 1938a, 79; Wibmer and O'Brien 1986a, 75; Morrone 1999, 124, O’Brien and Peña 2012, 5 (in key).

Compsus deliciosus Hustache, 1938: 80

Distribution: Colombia (Risaralda: Pereira).

References: Hustache 1938a, 80; Wibmer and O’Brien 1986a, 75; Morrone 1999, 124, O’Brien and Peña 2012, 5 (in key).

Compsus deplanatus Kirsch, 1868: 237

Distribution: Colombia ('Bogotá'), Venezuela.

References: Kirsch 1868, 237; Wibmer and O’Brien 1986a, 75; Morrone 1999, 124.

Compsus divisus Hustache, 1938: 82

Distribution: Colombia (Boyacá: Muzo).

References: Hustache 1938a, 82; Wibmer and O'Brien 1986a, 75; Morrone 1999, 124, O’Brien and Peña 2012, 5 (in key), Girón and Chamorro 2020, 40.

Compsus eustylodes Hustache, 1938: 96

Distribution: Colombia (Cundinamarca: Fusagasugá, Viotá; Meta: Villavicencio). 
References: Hustache 1938a, 96; Wibmer and O’Brien 1986a, 75; Morrone 1999, 124, O’Brien and Peña 2012, 3 (in key).

Compsus glaucus (Boheman, 1840: 178)

Distribution: Colombia (Antioquia).

References: Boheman in Schönherr 1840b, 178 as Platyomus glaucus, Wibmer and O'Brien 1986a, 75; Morrone 1999, 125.

Compsus iris Marshall, 1922: 198

Distribution: Colombia (Antioquia: Medellín).

References: Marshall 1922b, 198; Wibmer and O'Brien 1986a, 75; Morrone 1999, 125.

Compsus latifrons Hustache, 1938: 90

Distribution: Colombia (Pereira)

References: Hustache 1938a, 90; Wibmer and O’Brien 1986a, 76; Morrone 1999, 125, O’Brien and Peña 2012, 4 (in key).

Compsus lebasii (Boheman, 1840: 182)

Distribution: Colombia (Bolívar: Cartagena).

References: Boheman in Schönherr 1840b, 182; Hustache 1938a, 81; Wibmer and O'Brien 1986a, 76; Morrone 1999, 125, O’Brien and Peña 2012, 3 (in key).

\section{Compsus lineatus Hustache, 1938: 81}

Distribution: Colombia (S. Antonio)

References: Hustache 1938a, 81; Wibmer and O’Brien 1986a, 76; Morrone 1999, 125, O’Brien and Peña 2012, 3 (in key).

\section{Compsus obliquatus Hustache, 1938: 77}

Distribution: Colombia (Rio Chili; Cundinamarca: Beltrán; Tolima: Espinal).

References: Hustache 1938a, 77; Wibmer and O’Brien 1986a, 76; Morrone 1999, 125, O’Brien and Peña 2012, 4 (in key; p. 7 redescription). 
Compsus pertinax Hustache, 1938: 85

Distribution: Colombia (Cauca), Ecuador.

References: Hustache 1938a, 85; Wibmer and O’Brien 1986a, 76; Morrone 1999, 125, O’Brien and Peña 2012, 4 (in key).

\section{Compsus placidus (Boheman, 1840: 180)}

Distribution: Colombia [Nova Granata].

References: Boheman in Schönherr 1840b, 180 as Platyomus placidus, Wibmer and O’Brien 1986a, 76; Morrone 1999, 125.

\section{Compsus popayanus Kirsch, 1889: 21}

Distribution: Colombia (Popayán).

References: Kirsch 1889, 21; Wibmer and O’Brien 1986a, 76; Morrone 1999, 125.

Compsus pugionatus Marshall, 1922: 196

Distribution: Colombia, Venezuela; Central America.

References: Marshall 1922b, 196; Wibmer and O’Brien 1986a, 76; Morrone 1999, 125.

Compsus quadrisignatus (Boheman, 1840: 188)

Distribution: Colombia, French Guiana, Venezuela.

References: Boheman in Schönherr 1840b, 188 as Platyomus quadrisignatus, Wibmer and O'Brien 1986a, 76; Morrone 1999, 125.

Compsus roseomicans Hustache, 1938: 100

Distribution: Colombia (Boyacá: Muzo).

References: Hustache 1938a, 100; Wibmer and O'Brien 1986a, 76; Morrone 1999, 125, O’Brien and Peña 2012, 6 (in key).

Compsus scrutator Hustache, 1938: 98

Distribution: Brazil, Colombia (Cauca), Venezuela. 
References: Hustache 1938a, 98; Wibmer and O’Brien 1986a, 76; Morrone 1999, 125, O’Brien and Peña 2012, 6 (in key).

\section{Compsus violaceus Hustache, 1938: 89}

Distribution: Colombia (Rio Chili).

References: Hustache 1938a, 89; Wibmer and O’Brien 1986a, 77; Morrone 1999, 126, O’Brien and Peña 2012, 5 (in key), Girón and Chamorro 2020, 40.

Compsus viridissimus Hustache, 1938: 107

Distribution: Colombia (Boyacá: Muzo), Ecuador.

References: Hustache 1938a, 107; Wibmer and O'Brien 1986a, 77; Morrone 1999, 126, O’Brien and Peña 2012, 6 (in key).

Compsus viridivittatus (Guérin-Méneville, 1855: 592)

Distribution: Colombia (Antioquia (Támesis), Caldas (Chinchiná), Cundinamarca (Beltrán), Quindío (Armenia, La Tebaida, Montenegro), Risaralda (Belén de Umbría, Pereira), Santander (Lebrija), Tolima (Armero Guayabal, 4 Km SE Ibagué), Valle del Cauca (Caicedonia, Sevilla); Napo and Amazon rivers (Brazil (?), Ecuador (?), Peru (?)).

References: Guérin-Méneville 1855, 592 as Platyomus viridivittatus, Wibmer and O’Brien 1986a, 77; Morrone 1999, 126, O’Brien and Peña 2012, 4 (in key; p. 10 re-description).

\section{Compsus viridulus Hustache, 1938: 95}

Distribution: Colombia ('Bogotá').

References: Hustache 1938a, 95; Wibmer and O’Brien 1986a, 77; Morrone 1999, 126, O’Brien and Peña 2012, 4 (in key).

Compsus zebra Marshall, 1922: 199

Distribution: Colombia (Valle del Cauca: Buenaventura), Ecuador.

References: Marshall 1922b, 199; Wibmer and O’Brien 1986a, 77; Morrone 1999, 126. 


\section{Compsus zebrinus Voss, 1953: 57}

Distribution: Colombia [West Cordilleren. Rio Aguacatal, St. Antonio, Monte Socorro]. References: Voss 1953, 57; Wibmer and O’Brien 1986a, 77; Morrone 1999, 126.

Genus Eustylus Schönherr, 1842: 40

Distribution: Bolivia, Brazil, Colombia, French Guiana, Guyana, Paraguay, Peru, Trinidad, Venezuela; Costa Rica, Guatemala, Mexico, Panama; Guadeloupe, St. Lucia.

References: Schönherr 1842, 40; Sharp and Champion 1911, 290; Marshall 1916 (most Colombian species), Wibmer and O'Brien 1986a, 73; Alonso-Zarazaga and Lyal 1999, 158; Morrone 1999, 127.

Eustylus bodkini Marshall, 1916: 456

Distribution: Colombia, Guyana, Venezuela.

References: Marshall 1916, 456; Wibmer and O’Brien 1986a, 73; Morrone 1999, 127.

Eustylus ephippiatus Marshall, 1916: 458

Distribution: Colombia.

References: Marshall 1916, 458; Wibmer and O’Brien 1986a, 73; Morrone 1999, 127.

\section{Eustylus magdalenae Marshall, 1926: 536}

Distribution: Colombia (Magdalena: El Banco [El Blanco], Magdalena Valley; Aracataca).

References: Marshall 1926, 536; Wibmer and O’Brien 1986a, 73; Morrone 1999, 127.

Eustylus puber (Olivier, 1807: 367)

Distribution: Colombia, French Guiana, Guyana, Trinidad, Veneuela.

References: Olivier 1807, 367 (as Curculio puber), Wibmer and O'Brien 1986a, 73; Morrone 1999, 127; Franz 2010a, 56 (re-description).

Eustylus simplex Marshall, 1916: 460

Distribution: Colombia. 
References: Marshall 1916, 460; Wibmer and O’Brien 1986a, 73; Morrone 1999, 127.

\section{Eustylus simulatus Marshall, 1916: 459}

Distribution: Colombia.

References: Marshall 1916, 459; Wibmer and O’Brien 1986a, 73; Morrone 1999, 127.

\section{Eustylus sordidus Marshall, 1916: 460}

Distribution: Colombia.

References: Marshall 1916,460; Wibmer and O’Brien 1986a, 73; Morrone 1999, 127.

Genus Exophthalmus Schönherr, 1823: col. 1140

Distribution: Brazil, Colombia, Ecuador, French Guiana, Surinam; Belize, Costa Rica, El Salvador, Guatemala, Honduras, Mexico, Nicaragua, Panama; Cuba, Dominican Republic, Guadeloupe, Haiti, Jamaica, Martinique, Puerto Rico.

References: Schönherr 1823, col. 1140; Sharp and Champion 1911, 249, O'Brien and Wibmer 1982, 56; Wibmer and O'Brien 1986a, 79; Alonso-Zarazaga and Lyal 1999, 158; Morrone 1999, 127; Franz 2012 (part).

Exophthalmus annulonotatus (Waterhouse, 1879: 423)

Distribution: Colombia (Antioquia: Medellín), Ecuador.

References: Waterhouse 1879, 423 (as Paepodes annulonotatus), Wibmer and O’Brien 1986a, 79; Morrone 1999, 128.

\section{Exophthalmus consobrinus (Marshall, 1922b: 190)}

Distribution: Colombia (Chocó: Andagoya, Río Condoto; Valle del Cauca (Buenaventura).

References: Marshall 1922b, 190 (as Exophthalmodes consobrinus), Wibmer and O’Brien 1986a, 79; Morrone 1999, 128. 
References: Kirsch 1868, 238, O’Brien and Wibmer 1982, 56; Wibmer and O’Brien 1986a, 79; Morrone 1999, 128.

Exophthalmus jekelianus (White, 1858: 357)

Distribution: Colombia (Chocó); Costa Rica, Nicaragua, Panama.

References: White in Jekel 1858, 357 (as Praepodes jekelianus), O'Brien and Wibmer 1982, 57; Wibmer and O’Brien 1986a, 79; Morrone 1999, 128.

Exophthalmus sulcicrus Champion, 1911: 268

Distribution: Colombia (Chocó); Costa Rica, Guatemala, Nicaragua, Panama.

References: Sharp and Champion 1911, 268, O’Brien and Wibmer 1982, 58;

Wibmer and O’Brien 1986a, 79; Morrone 1999, 129.

Genus Exorides Pascoe, 1881: 43

Distribution: Colombia, Ecuador, Peru, Venezuela.

References: Pascoe 1881, 43; Marshall 1922b, 202; Wibmer and O’Brien 1986a, 80; Alonso-Zarazaga and Lyal 1999, 158; Morrone 1999, 130.

Exorides bifurcatus Marshall, 1926: 537

Distribution: Colombia (Magdalena: Sierra de San Lorenzo).

References: Marshall 1926, 537; Wibmer and O’Brien 1986a, 80; Morrone 1999, 130.

Exorides caudatus Marshall, 1922: 217

Distribution: Colombia ('Bogotá').

References: Marshall 1922b, 217; Wibmer and O’Brien 1986a, 80; Morrone 1999, 130.

Exorides cylindricus Marshall, 1922: 213

Distribution: Colombia (Magdalena, San Lorenzo Mt.).

References: Marshall 1922b, 213; Wibmer and O’Brien 1986a, 80; Morrone 1999, 130. 
Exorides espeletiae (Kirsch, 1889: 23)

Distribution: Colombia ('Bogotá).

References: Kirsch 1889, 23 (as Compsus espeletiae), Marshall 1922b, 217; Wibmer and O’Brien 1986a, 80; Morrone 1999, 130.

Exorides labyrinthicus (Kirsch, 1889: 22)

Distribution: Colombia (Pasto, Santa Lucía).

References: (Kirsch 1889, 22 (as Compsus labyrinthicus), Marshall 1922b, 203;

Wibmer and O'Brien 1986a, 80; Morrone 1999, 130).

\section{Exorides lindigi (Kirsch, 1889: 24)}

Distribution: Colombia (Bogotá).

References: Kirsch 1889, 24 (as Compsus lindigi), Marshall 1922b, 205 (in key), Wibmer and O'Brien 1986a, 80; Morrone 1999, 130.

Exorides marshalli (Bovie, 1908b: 44)

Distribution: Colombia.

References: Bovie 1908b, 44 (as Compsus marshalli), Wibmer and O'Brien 1986a, 80; Morrone 1999, 130.

\section{Exorides masoni Marshall, 1922: 215}

Distribution: Colombia (Magdalena, San Lorenzo Mt.).

References: Marshall 1922b, 215; Wibmer and O’Brien 1986a, 80; Morrone 1999, 130.

Exorides mucronatus (Faust, 1892: 18)

Distribution: Colombia, Venezuela.

References: Faust 1892, 18 (as Synthlibonotus mucronatus), Marshall 1922b, 214;

Wibmer and O'Brien 1986a, 80; Morrone 1999, 130. 
Exorides obesus Marshall, 1922: 209

Distribution: Colombia.

References: Marshall 1922b, 209; Wibmer and O’Brien 1986a, 80; Morrone 1999, 130.

\section{Exorides pyriformis Marshall, 1922: 211}

Distribution: Colombia.

References: Marshall 1922b, 211; Wibmer and O’Brien 1986a, 80; Morrone 1999, 130.

Exorides quadrivittatus (Kirsch, 1889: 23)

Distribution: Colombia (Pasto, Santa Lucía).

References: Kirsch 1889, 23; Marshall 1922b, 206; Wibmer and O’Brien 1986a, 80; Morrone 1999, 130.

\section{Exorides rugosus (Taschenberg, 1870: 188)}

Distribution: Colombia ('Bogotá').

References: Taschenberg 1870, 188 (as Compsus rugosus), Marshall 1922b, 204; Wibmer and O'Brien 1986a, 80; Morrone 1999, 130.

Exorides septemcostatus Marshall, 1922: 212

Distribution: Colombia, Ecuador.

References: Marshall 1922b, 212; Wibmer and O’Brien 1986a, 80; Morrone 1999, 130.

Genus Oxyderces Schönherr, 1823: col. 1140

Distribution: Argentina, Bolivia, Brazil, Colombia, Ecuador, Paraguay, Peru, Venezuela; Guadeloupe, Martinique.

References: Schönherr 1823, col. 1140; Marshall 1922b, 201 (as Plococompsus), O'Brien and Wibmer 1982, 58; Wibmer and O'Brien 1986a, 80; Alonso-Zarazaga and Lyal 1999, 158; Morrone 1999, 130; Girón and Chamorro 2020, 41 (part). 


\section{Oxyderces exaratus (Hustache, 1938a: 111)}

Distribution: Colombia [Columbia] ([Transylvanie] Pensilvania, Cundinamarca (?))). References: Hustache 1938a, 111 (as Plococompsus exaratus), Wibmer and O’Brien 1986a, 81; Morrone 1999, 130.

Oxyderces mirandus (Pascoe, 1880: 423)

Distribution: Colombia [Columbia] (Boyacá: Muzo), Ecuador.

References: Pascoe 1880, 423; Marshall 1922b, 201 (listed as Compsus mirandus), Hustache 1938a, 114 (as Plococompsus texatus), Wibmer and O'Brien 1986a, 81; Morrone 1999, 131.

\section{Oxyderces viridiaeris (Hustache, 1938a: 115)}

Distribution: Colombia.

References: Hustache 1938a, 115 (as Plococompsus viridiaeris), Wibmer and O’Brien 1986a, 81; Morrone 1999, 131.

\section{Oxyderces viridipes (Boheman, 1840: 179)}

Distribution: Colombia (Antioquia).

References: Boheman in Schönherr 1840b, 179 (as Platyomus viridipes), Wibmer and O'Brien 1986a, 81; Morrone 1999, 131.

Genus Synthlibonotus Schönherr, 1847: 41 [91]

Distribution: Colombia, Venezuela; Guatemala, Mexico.

References: Schönherr 1847, 41 [91], O’Brien and Wibmer 1982, 58; Wibmer and O'Brien 1986a, 81; Alonso-Zarazaga and Lyal 1999, 158; Morrone 1999, 132.

Synthlibonotus rufipes Schönherr, 1847: 41 [91]

Distribution: Colombia, Venezuela.

References: Schönherr 1847, 41 [91], Wibmer and O'Brien 1986a, 81; Morrone 1999, 132. 
Genus Xestogaster Marshall, 1922: 221

Distribution: Brazil, Colombia, Peru.

References: Marshall 1922b, 221; Wibmer and O’Brien 1986a, 81; AlonsoZarazaga and Lyal 1999, 158; Morrone 1999, 132.

Xestogaster porosa Marshall, 1922: 221

Distribution: Colombia ('Bogotá').

References: Marshall 1922b, 221; Wibmer and O'Brien 1986a, 81; Morrone 1999, 132.

Xestogaster squalida Marshall, 1922: 222

Distribution: Colombia.

References: Marshall 1922b, 222; Wibmer and O'Brien 1986a, 81; Morrone 1999, 132.

Tribe Lordopini Schönherr, 1823: col. 1142

Genus Acanthobrachis Jekel, 1854 [1857]-I: 9bis (in key) [1857: 101]

Distribution: Brazil, Colombia.

References: Jekel 1857, 101; Kessel 1932, 35; Wibmer and O'Brien 1986a, 91; Alonso-Zarazaga and Lyal 1999, 161; Morrone 1999, 109.

Acanthobrachis germari Jekel, 1857: 103

Distribution: Brazil, Colombia.

References: Jekel 1857, 103; Kessel 1932, 35; Wibmer and O'Brien 1986a, 91; Morrone 1999, 109.

\section{Genus Atomorhinus Hustache, 1946: 3}

Distribution: Colombia.

References: Hustache 1946, 3, Wibmer and O’Brien 1986a, 94; Alonso-Zarazaga and Lyal 1999, 161; Morrone 1999, 110. 
Atomorhinus impressidorsum Hustache, 1946: 4

Distribution: Colombia (Cauca, Rio Chili; Cundinamarca: Fusagasugá).

References: Hustache 1946, 4, Wibmer and O’Brien 1986a, 94; Morrone 1999, 110.

Genus Deroconus Jekel, 1854 [1857]-I: 9bis (in key)

Distribution: Colombia, Venezuela.

References: Jekel 1857; Kessel 1932, 62 (as Deraconus), Wibmer and O'Brien 1986a, 93; Alonso-Zarazaga and Lyal 1999, 161; Morrone 1999, 111.

Deroconus rufipes (Lacordaire, 1863: 269)

Distribution: Colombia, Venezuela.

References: Lacordaire 1863, 269 (as Hypsonotus rufipes), Kessel 1932, 66 (as Deraconus rufipes), Wibmer and O’Brien 1986a, 93; Morrone 1999, 111.

Genus Eudmetus Jekel, 1856: 9bis [1857: 105]

Distribution: Colombia.

References: Jekel 1857, 105; Kessel 1932, 37 (in key), Wibmer and O'Brien 1986a, 91; Alonso-Zarazaga and Lyal 1999, 161; Morrone 1999, 112.

Eudmetus cinereus Jekel, 1857: 107

Distribution: Colombia.

References: Jekel 1857, 107; Wibmer and O’Brien 1986a, 91; Morrone 1999, 112.

\section{Eudmetus nigromaculatus Jekel, 1857: 111}

Distribution: Colombia.

References: Jekel 1856, 111; Wibmer and O’Brien 1986a, 91; Morrone 1999, 112.

\section{Eudmetus posticatus Jekel, 1857: 109}

Distribution: Colombia.

References: Jekel 1857, 109; Wibmer and O’Brien 1986a, 91; Morrone 1999, 112. 
Genus Granadia Kessel, 1935: 95

Distribution: Colombia.

References: Kessel 1935, 95 (not seen), Wibmer and O’Brien 1986a, 95; AlonsoZarazaga and Lyal 1999, 161; Morrone 1999, 113.

\section{Granadia humeralis Kessel, 1935: 96}

Distribution: Colombia.

References: Kessel 1935, 96 (not seen), Wibmer and O'Brien 1986a, 95; Morrone 1999, 113.

Genus Hypoptophila Voss, 1934: 102

Distribution: Brazil, Colombia.

References: Voss 1934, 102; Wibmer and O'Brien 1986a, 93; Alonso-Zarazaga and Lyal 1999, 161; Morrone 1999, 113.

\section{Hypoptophila munda Voss, 1934: 102}

Distribution: Colombia [Nov. Granada].

References: Voss 1934, 102; Wibmer and O’Brien 1986a, 93; Morrone 1999, 113.

Genus Hypoptus Jekel 1856: 9bis (in key)

Distribution: Bolivia, Colombia, Ecuador; Belize, Costa Rica, El Salvador, Guatemala, Mexico, Nicaragua, Panama; Grenada, St. Vincent.

References: Jekel 1856; Kessel 1932, 57 (incl. key), Wibmer and O’Brien 1986a, 93; Alonso-Zarazaga and Lyal 1999, 161; Morrone 1999, 113.

\section{Hypoptus arcticus Kessel, 1932: 62}

Distribution: Colombia ([Magdalenenstrom] Magdalena river).

References: Kessel 1932, 62; Wibmer and O’Brien 1986a, 93; Morrone 1999, 113. 
References: Kessel 1932, 63; Wibmer and O’Brien 1986a, 93; Morrone 1999, 113.

Hypoptus macularis Champion, 1911: 303

Distribution: Colombia; Belize, Costa Rica, El Salvador, Guatemala, Mexico, Nicaragua, Panama.

References: Sharp and Champion 1911, 303; Kessel 1932, 61; Wibmer and O’Brien 1986a, 93; Morrone 1999, 113.

Hypoptus setosulus Kessel, 1932: 64

Distribution: Colombia.

References: Kessel 1932, 64; Wibmer and O’Brien 1986a, 93; Morrone 1999, 113.

Genus Hypsonotus Germar, 1824: 367

Distribution: Argentina, Bolivia, Brazil, Colombia, Ecuador, Paraguay, Venezuela; Costa Rica, Guatemala, Honduras, Mexico; St. Vincent.

References: Germar 1824, 367; Jekel 1854, 137, O’Brien and Wibmer 1982, 66; Wibmer and O'Brien 1986a, 96; Alonso-Zarazaga and Lyal 1999, 162; Morrone 1999, 113.

Hypsonotus acutipennis Jekel, 1859: 229

Distribution: Colombia ('Bogotá).

References: Jekel 1856, 160 (listed), 1859, 229 (described), Wibmer and O'Brien 1986a, 97; Morrone 1999, 113.

\section{Hypsonotus apicatus Jekel, 1857: 173}

Distribution: Colombia ('Bogotá').

References: Jekel 1857, 145 (listed), 1859, 173 (described), Wibmer and O'Brien 1986a, 97; Morrone 1999, 114.

Hypsonotus bipunctatus Jekel, 1859: 233

Distribution: Colombia. 
References: Jekel 1856, 160 (listed), 1859, 233 (described), Wibmer and O'Brien 1986a, 97; Morrone 1999, 114.

Hypsonotus callosicollis Jekel, 1857: 179

Distribution: Brazil, Colombia.

References: Jekel 1857, 146 (listed), 179 (described), Wibmer and O'Brien 1986a, 97; Morrone 1999, 114.

Hypsonotus compressipennis Jekel, 1859: 235

Distribution: Colombia.

References: Jekel 1857, 160 (listed), 1859, 235 (described), Wibmer and O'Brien 1986a, 97; Morrone 1999, 114.

\section{Hypsonotus glaber Kessel, 1937: 170}

Distribution: Colombia.

References: Kessel 1937, 170 (not seen), Wibmer and O’Brien 1986a, 98; Morrone 1999, 114.

Hypsonotus hondurensis Kessel, 1937: 161

Distribution: Colombia; Honduras.

References: Kessel 1937, 161 (not seen), O'Brien and Wibmer 1982, 66; Wibmer and O’Brien 1986a, 98; Morrone 1999, 115.

Hypsonotus interior Kessel, 1937: 171

Distribution: Colombia.

References: Kessel 1937, 171 (not seen), Wibmer and O’Brien 1986a, 98; Morrone 1999, 115.

Hypsonotus laevicollis Jekel, 1859: 227

Distribution: Colombia ('Bogotá). 
References: Jekel 1857, 160 (listed), 1859, 227 (described), Wibmer and O’Brien 1986a, 98; Morrone 1999, 115

Hypsonotus latissimus Kessel, 1937: 125

Distribution: Colombia.

References: Kessel 1937, 125 (not seen), Wibmer and O’Brien 1986a, 98; Morrone 1999, 115.

\section{Hypsonotus limbifer Kessel, 1937: 155}

Distribution: Colombia.

References: Kessel 1937, 155 (not seen), Wibmer and O’Brien 1986a, 98; Morrone 1999, 115.

\section{Hypsonotus nitidulus Jekel, 1859: 237}

Distribution: Colombia.

References: Jekel 1857, 160 (listed), 1859, 237 (described), Wibmer and O'Brien 1986a, 98; Morrone 1999, 115.

Hypsonotus obsoletus Jekel, 1857: 155

Distribution: Brazil, Colombia.

References: Jekel 1857, 155 (listed), 1859, 227 (described), Wibmer and O'Brien 1986a, 99; Morrone 1999, 115.

\section{Hypsonotus punctum Jekel, 1859: 231}

Distribution: Colombia.

References: Jekel 1857, 160 (listed), 1859, 231 (described), Wibmer and O'Brien 1986a, 99; Morrone 1999, 116.

Hypsonotus ramosus Jekel, 1859: 225

Distribution: Colombia. 
References: Jekel 1856, 160 (listed), 1859, 225 (described), Wibmer and O'Brien 1986a, 99; Morrone 1999, 116.

\section{Hypsonotus setarius Jekel, 1857: 156}

Distribution: Colombia.

References: Jekel 1857, 156; Wibmer and O’Brien 1986a, 99; Morrone 1999, 116.

\section{Hypsonotus vestitus Jekel, 1859: 223}

Distribution: Colombia.

References: Jekel 1856, 159 (listed), 1859, 223 (described), Wibmer and O'Brien 1986a, 99; Morrone 1999, 116.

Genus Lordops Schönherr, 1823: col. 1142

Distribution: Argentina, Brazil, Colombia, Paraguay, Venezuela; Mexico.

References: Schönherr 1823, col. 1142; Jekel 1854, I.II.7, Kessel 1932, 1 (including key to species), O'Brien and Wibmer 1982, 66; Wibmer and O'Brien 1986a, 89; Alonso-Zarazaga and Lyal 1999, 162; Morrone 1999, 116.

Lordops conjugatus Jekel, 1854: I.V.7

Distribution: Brazil, Colombia ('Bogotá), Paraguay.

References: Jekel 1854, I.V.7, Kessel 1932, 7 (in key; p. 30 comments), Wibmer and O’Brien 1986a, 90; Morrone 1999, 117.

Genus Orthocnemus Jekel, 1856: 131

Distribution: Colombia, Ecuador, Peru.

References: Jekel 1856, 131; Kessel 1932, 40; Wibmer and O'Brien 1986a, 92; Alonso-Zarazaga and Lyal 1999, 162; Morrone 1999, 118.

\section{Orthocnemus lebasii Jekel, 1857: 133}

Distribution: Colombia ('Bogotá').

References: Jekel 1857, 133; Kessel 1932, 41; Wibmer and O’Brien 1986a, 92; Morrone 1999, 118. 


\section{Genus Sulla Kessel, 1937: 182}

Distribution: Colombia.

References: Kessel 1937, 182; Wibmer and O’Brien 1986a, 91 (as Sullana), Alonso-Zarazaga and Lyal 1999, 162; Morrone 1999, 121 (as Sullana).

\section{Sulla columbiana Kessel, 1937: 183}

Distribution: Colombia.

References: Kessel 1937, 183; Wibmer and O’Brien 1986a, 91 (as Sullana columbiana), Morrone 1999, 121 (as Sullana columbiana).

\section{Tribe Naupactini Gistel, 1856: 374}

Genus Amphideritus Schönherr, 1840: 117

Distribution: Bolivia, Chile, Colombia, Peru.

References: Schönherr 1840b, 117; Wibmer and O'Brien 1986a, 55; AlonsoZarazaga and Lyal 1999, 163; Morrone 1999, 154 (as synonym of Macrostylus), del Río and Lanteri 2011a.

\section{Amphideritus rugicollis Kirsch, 1868: 223}

Distribution: Colombia ('Bogotá').

References: Kirsch 1868, 223; Wibmer and O'Brien 1986a, 55; Morrone 1999, 156.

\section{Amphideritus setosus (Schönherr, 1847: 29)}

Distribution: Colombia (Bogotá).

References: Schönherr 1847, 29 (as Pterotropis setosus); Kirsch 1868, 224 (as Amphideritus squamosus, a synonym), Wibmer and O'Brien 1986a, 55; Morrone 1999, 156.

\section{Amphideritus vilis Boheman, 1840: 118}

Distribution: Colombia (Bogotá).

References: Boheman in Schönherr 1840b, 118; Wibmer and O'Brien 1986a, 55; Morrone 1999, 156. 
Genus Asymmathetes Wibmer and O’Brien, 1986: 53

Distribution: Colombia, Ecuador.

References: Wibmer and O'Brien 1986a, 53; Alonso-Zarazaga and Lyal 1999, 164; Morrone 1999, 151.

\section{Asymmathetes steinheili (Kirsch, 1889: 13)}

Distribution: Colombia (Consacá).

References: Kirsch 1889, 13 (as Naupactus steinheili), Wibmer and O'Brien 1986a, 53; Morrone 1999, 151.

Genus Chamaelops Kirsch, 1868: 235

Distribution: Colombia.

References: Kirsch 1868, 235; Wibmer and O’Brien 1986a, 51; Alonso-Zarazaga and Lyal 1999, 164; Morrone 1999, 152.

\section{Chamaelops fissirostris (Chevrolat, 1878: LV)}

Distribution: Colombia ('Bogotá').

References: Chevrolat 1878, LV (as Temnoscapus fissirostris), Wibmer and O’Brien 1986a, 51; Morrone 1999, 151.

\section{Chamaelops munitus Kirsch, 1868: 236}

Distribution: Colombia ('Bogotá').

References: Kirsch 1868, 236; Wibmer and O'Brien 1986a, 51; Morrone 1999, 152.

Genus Ericydeus Pascoe, 1880: 422

Distribution: Argentina, Bolivia, Brazil, Colombia, Ecuador, French Guiana, Peru, Venezuela; Costa Rica, Mexico; SW USA.

References: Pascoe 1880, 422; Wibmer and O’Brien 1986a, 51; Lanteri 1995; Alonso-Zarazaga and Lyal 1999, 164; Morrone 1999, 152. 
Ericydeus nigropunctatus (Chevrolat, 1877: 170)

Distribution: Colombia (Guainía), Ecuador, Peru, Venezuela.

References: Chevrolat 1877, 170 (as Cyphus nigropunctatus), Wibmer and O’Brien 1986a, 51; Lanteri 1995, 402; Morrone 1999, 152.

Ericydeus sedecimpunctatus (Linnaeus, 1758: 386)

Distribution: Argentina, Bolivia, Brazil, Colombia, French Guiana, Guyana, Venezuela; Costa Rica, Panama.

References: Linnaeus 1758, 386 (as Curculio 16-punctatus), Wibmer and O'Brien 1986a, 51; Lanteri 1995, 404; Morrone 1999, 153.

Genus Hoplopactus Jekel, 1875: 138

Distribution: Bolivia, Brazil, Colombia, Ecuador, French Guiana, Peru, Trinidad, Venezuela.

References: (Jekel 1875, 138; Wibmer and O’Brien 1986a, 54; Alonso-Zarazaga and Lyal 1999, 164; Morrone 1999, 153).

\section{Hoplopactus dentipes (Kirsch, 1868: 231)}

Distribution: Colombia ('Bogotá').

References: Kirsch 1868, 231 (as Mimographus dentipes), Wibmer and O'Brien 1986a, 54; Morrone 1999, 153.

Hoplopactus pavidus (Boheman, 1840: 107)

Distribution: Colombia, Trinidad, Venezuela.

References: Boheman in Schönherr 1840b, 107 (as Naupactus pavidus), Wibmer and O'Brien 1986a, 54; Morrone 1999, 154.

\section{Hoplopactus rufipes (Kirsch, 1868: 230)}

Distribution: Colombia ('Bogotá').

References: Kirsch 1868, 230 (as Mimographus rufipes), Wibmer and O'Brien 1986a, 54; Morrone 1999, 154. 
Hoplopactus suturalis (Kirsch, 1868: 230)

Distribution: Colombia ('Bogotá').

References: Kirsch 1868, 230 (as Mimographus suturalis), Wibmer and O’Brien 1986a, 54; Morrone 1999, 154.

Genus Lanterius Alonso-Zarazaga y Lyal, 1999

Distribution: Argentina, Brazil, Colombia, Ecuador, Paraguay, Venezuela; Mexico. Panama.

References: Alonso-Zarazaga and Lyal 1999, 164, del Río and Lanteri 2018, 331.

Lanterius amandus (Kirsch, 1868: 225)

Distribution: Colombia ('Bogotá'); Panama.

References: Kirsch 1868, 225 (as Mimographus amandus), Wibmer and O'Brien 1986a, 56 (as Mimographus amandus), Alonso-Zarazaga and Lyal 1999, 164; Morrone 1999, 154 (as Macrostylus amandus).

Lanterius ardosiacus (Kirsch, 1868: 229), comb. nov.

Distribution: Colombia ('Bogotá').

References: Kirsch 1868, 229 (as Mimographus ardosiacus), Wibmer and O'Brien 1986a, 56 (as Mimographus ardosiacus), Morrone 1999, 155 (as Macrostylus ardosiacus).

Lanterius cinereoguttatus (Champion, 1911: 228), comb. nov.

Distribution: Colombia, Venezuela; Central America (unspecified).

References: Sharp and Champion 1911, 228 (as Steirarrhinus cinereoguttatus), Wibmer and O’Brien 1986a, 56 (as Mimographus cinereoguttatus), Morrone 1999, 155 (as Macrostylus cinereoguttatus).

Lanterius hirtus (Voss, 1953: 60), comb. nov.

Distribution: Colombia ([West Cordilleren, Rio Aguacatal $]$ ).

References: Voss 1953, 60 (as Neoanypotactus hirtus), Wibmer and O'Brien 1986a, 56 (as Mimographus hirtus), Morrone 1999, 155 (as Macrostylus hirtus). 
Lanterius laesicollis (Schönherr, 1847: 35), comb. nov.

Distribution: Colombia, Venezuela.

References: Schönherr 1847, 35 (as Mimographus laesicollis), Wibmer and O’Brien 1986a, 56 (as Mimographus laesicollis), Morrone 1999, 155 (as Macrostylus laesicollis).

Lanterius micans (Kirsch, 1868: 229), comb. nov.

Distribution: Colombia ('Bogotá').

References: Kirsch 1868, 229 (as Mimographus micans), Wibmer and O'Brien 1986a, 56 (as Mimographus micans), Morrone 1999, 155 (as Macrostylus micans).

Lanterius rotundicollis (Kirsch, 1889: 15), comb. nov.

Distribution: Colombia (Popayán).

References: Kirsch 1889, 15 (as Mimographus rotundicollis), Wibmer and O'Brien 1986a, 56 (as Mimographus rotundicollis), Morrone 1999, 156 (as Macrostylus rotundicollis).

Lanterius versicolor (Kirsch, 1889: 15), comb. nov.

Distribution: Colombia ('Pasto').

References: Kirsch 1889, 15 (as Mimographus versicolor), Wibmer and O’Brien 1986a, 56 (as Mimographus versicolor), Morrone 1999, 156 (as Macrostylus versicolor).

Lanterius vittatus (Kirsch, 1889: 14), comb. nov.

Distribution: Colombia ('Pasto').

References: Kirsch 1889, 14 (as Mimographus vittatus), Wibmer and O'Brien 1986a, 56 (as Mimographus vittatus), Morrone 1999, 156 (as Macrostylus vittatus).

Genus Leschenius del Río, Marvaldi y Lanteri, 2012: 55

Distribution: Colombia, Ecuador.

References: del Río et al. 2012, 55. 
Leschenius vulcanorum (Kirsch, 1889: 17)

Distribution: Colombia (Nariño), Ecuador.

References: Kirsch 1889, 17 (as Canephorus vulcanorum), Wibmer and O'Brien 1986a, 53 (as Asymmathetes vulcanorum), Canchala 1992; Morrone 1999, 151 (as Asymmathetes vulcanorum), del Río et al. 2012, 62.

Genus Litostylus Faust, 1894: 368

Distribution: Argentina, Brazil, Colombia, French Guiana, Peru, Venezuela; Honduras, Nicaragua, Panama; Antigua, Barbados, Dominica, Guadeloupe, Martinique, Montserrat, Saint Barthelemy, Saint Vincent.

References: Faust 1894, 368, O'Brien and Wibmer 1982, 32; Wibmer and O'Brien 1986a, 48; Alonso-Zarazaga and Lyal 1999, 164; Morrone 1999, 154.

Litostylus diadema (Fabricius, 1787: 116)

Distribution: Argentina, Brazil, Colombia, French Guiana, Peru, Venezuela; Honduras, Nicaragua, Panama.

References: Fabricius 1787, 116 (as Curculio diadema), O'Brien and Wibmer 1982, 32; Wibmer and O'Brien 1986a, 48; Morrone 1999, 154.

Genus Melanocyphus Jekel, 1875: 143

Distribution: Colombia.

References: Jekel 1875, 143; Wibmer and O'Brien 1986a, 54; Alonso-Zarazaga and Lyal 1999, 164; Morrone 1999, 156, del Río and Lanteri 2007a, 2011 a, 59 (in key).

\section{Melanocyphus bispinus (Boheman, 1840: 150)}

Distribution: Colombia (Bogotá).

References: Boheman in Schönherr 1840b, 150 (as Cyphus bispinus), Wibmer and O’Brien 1986a, 54; Morrone 1999, 156, del Río and Lanteri 2007a, 131.

\section{Melanocyphus lugubris (Boheman, 1840: 147)}

Distribution: Colombia (Bogotá).

References: Boheman in Schönherr 1840b, 147 (as Naupactus lugubris), Wibmer and O’Brien 1986a, 54; Morrone 1999, 156, del Río and Lanteri 2007a, 130. 
Genus Mimographus Schönherr, 1847: 34

Distribution: Colombia, Peru; Belize, Costa Rica, Guatemala, Mexico, Nicaragua, Panama.

References: Schönherr 1847, 34; Wibmer and O’Brien 1986a, 56 (as Steirarrhinus), Alonso-Zarazaga and Lyal 1999, 165; Morrone 1999, 154 (as Macrostylus).

Mimographus decolor (Boheman, 1840: 106)

Distribution: Colombia; Central America (unspecified).

References: Boheman in Schönherr 1840b, 106 (as Naupactus decolor), Sharp and Champion 1911, 223 (as Steirarrhinus conicollis, a synonym), O'Brien and Wibmer 1982, 32 (as Steirarrhinus conicollis), Wibmer and O'Brien 1986a, 56 (as Steirarrhinus decolor), Morrone 1999, 155 (as Macrostylus decolor).

\section{Mimographus depressicollis (Boheman, 1840: 66)}

Distribution: Colombia (Antioquia).

References: Boheman in Schönherr 1840b, 66 (as Naupactus depressicollis), Wibmer and O'Brien 1986a, 56 (as Steirarrhinus depressicollis), Morrone 1999, 155 (as Macrostylus depressicollis).

\section{Mimographus elegantulus (Boheman, 1840: 64)}

Distribution: Colombia (Antioquia).

References: Boheman in Schönherr 1840b, 64 (as Naupactus elegantulus), Wibmer and O'Brien 1986a, 56 (as Steirarrhinus elegantulus), Morrone 1999, 155 (as Macrostylus elegantulus).

Mimographus plicaticollis (Hustache, 1938b: 274)

Distribution: Colombia (Cundinamarca (Fusagasugá), Valle del Cauca (Cali), San Antonio, Rio Cauca).

References: Hustache 1938b, 274 (as Naupactus plicaticollis), Wibmer and O'Brien 1986a, 56 (as Steirarrhinus plicaticollis), Morrone 1999, 155 (as Macrostylus plicaticollis).

\section{Mimographus varians (Boheman, 1840: 65)}

Distribution: Colombia (Antioquia). 
References: Boheman in Schönherr 1840b, 65 (as Naupactus varians), Wibmer and O’Brien 1986a, 56 (as Steirarrhinus varians), Morrone 1999, 155 (as Macrostylus varians).

Genus Naupactus Dejean, 1821: 94

Distribution: Argentina, Bolivia, Brazil, Chile, Colombia, Ecuador, French Guiana, Guyana, Paraguay, Peru, Surinam, Uruguay, Venezuela; Costa Rica, Guatemala, Honduras, Mexico; SE, SW USA.

References: Dejean 1821, 94; Wibmer and O’Brien 1986a, 57; Lanteri and Morrone 1995; Bordón 1997; Alonso-Zarazaga and Lyal 1999, 165; Morrone 1999, 157; Scataglini et al. 2005; Rosas et al. 2011; Lanteri and del Río 2016a, 2017, del Río et al. 2018, del Río and Lanteri 2019.

Naupactus instabilis Boheman, 1840: 71

Distribution: Colombia, Venezuela.

References: Boheman in Schönherr 1840b, 71; Wibmer and O’Brien 1986a, 60; Morrone 1999, 159.

Naupactus venezolanus Hustache, 1938: 270

Distribution: Colombia, Venezuela.

References: Hustache 1938b, 270, O’Brien and Wibmer 1982, 33 (as Alceis venezolanus), Wibmer and O’Brien 1986a, 62; Morrone 1999, 162.

Genus Platyomus Sahlberg, 1823: 29

Distribution: Argentina, Bolivia, Brazil, Colombia**, Ecuador, Guyana, Paraguay, Peru, Uruguay, Venezuela; Belize, Costa Rica, El Salvador, Guatemala, Honduras. Mexico; SW USA (Texas).

References: Sahlberg 1823, 29; Wibmer and O’Brien 1986a, 49; Alonso-Zarazaga and Lyal 1999, 165; Morrone 1999, 163; Lanteri and del Río 2016 a.

\section{Undetermined species}

Distribution: Colombia (Amazonas, Antioquia, Meta, Quindío, Risaralda, Valle del Cauca).

References: Girón 2007b; Cardona-Duque et al. 2018, 254-255. 
Genus Plectrophoroides Wibmer and O’Brien, 1986: 50

Distribution: Argentina, Bolivia, Brazil, Colombia, French Guiana, Guyana, Peru, Surinam, Venezuela.

References: Wibmer and O'Brien 1986a, 50; Alonso-Zarazaga and Lyal 1999, 165; Morrone 1999, 164.

\section{Plectrophoroides acuminatus (Chevrolat, 1879: LXXVII)}

Distribution: Colombia.

References: Chevrolat 1879, LXXVII (as Plectrophorus acuminatus), Wibmer and O’Brien 1986a, 50; Morrone 1999, 164.

\section{Plectrophoroides albilabris (Chevrolat, 1879: LXXVIII)}

Distribution: Colombia ('Bogotá').

References: Chevrolat 1879, LXXVIII (as Plectrophorus albilabris), Wibmer and O’Brien 1986a, 50; Morrone 1999, 164.

Plectrophoroides bifasciatus (Chevrolat, 1879: LXXVII)

Distribution: Bolivia, Colombia.

References: Chevrolat 1879, LXXVII (as Plectrophorus bifasciatus), Wibmer and O’Brien 1986a, 50; Morrone 1999, 164.

Genus Tetragonomus Champion, 1911: 240

Distribution: Colombia; Panama.

References: Sharp and Champion 1911, 240, O'Brien and Wibmer 1982, 32; Wibmer and O'Brien 1986a, 51; Alonso-Zarazaga and Lyal 1999, 165; Morrone 1999, 165.

Tetragonomus tuberosus Champion, 1911: 240

Distribution: Colombia; Panama.

References: Sharp and Champion 1911, 240, O'Brien and Wibmer 1982, 32; Wibmer and O'Brien 1986a, 51; Morrone 1999, 165. 
Tribe Premnotrypini Kuschel, 1956: 187

Genus Premnotrypes Pierce, 1914: 348

Distribution: Bolivia, Chile, Colombia, Ecuador, Peru, Venezuela.

References: Pierce 1914, 348; Kuschel 1956, 204; Wibmer and O'Brien 1986a, 89; Alonso-Zarazaga and Lyal 1999, 176; Morrone 1999, 107.

Premnotrypes vorax (Hustache, 1933: 377)

Distribution: Colombia ('Bogotá').

References: Hustache 1933, 377 (as Solanophagus vorax), Kuschel 1956, 209; Wibmer and O’Brien 1986a, 89; Morrone 1999, 107.

\section{Tribe Tanymecini Lacordaire, 1863: 82}

Genus Airosimus Howden, 1966: 174

Distribution: Bolivia, Brazil, Colombia, Ecuador, Peru, Paraguay, Venezuela; Costa Rica, Mexico, Panama.

References: Howden 1966; Wibmer and O’Brien 1986a, 71; Alonso-Zarazaga and Lyal 1999, 178; Morrone 1999, 143.

Airosimus robustus (Faust, 1892: 4)

Distribution: Colombia, Venezuela.

References: Faust 1892, 4 (as Menetypus robustus), Howden 1966, 196; Wibmer and O’Brien 1986a, 71; Morrone 1999, 143.

\section{Airosimus semirobustus Howden, 1966: 199}

Distribution: Colombia.

References: Howden 1966, 199; Wibmer and O’Brien 1986a, 71; Morrone 1999, 143.

Genus Hadromeropsis Pierce, 1913: 400

Distribution: Argentina, Bolivia, Brazil, Colombia, Ecuador, Paraguay, Peru, Uruguay, Venezuela; Costa Rica, Guatemala, Mexico, Panama. 
References: Pierce 1913, 400; Howden 1982; Wibmer and O’Brien 1986a, 68; Alonso-Zarazaga and Lyal 1999, 179; Morrone 1999, 143.

Hadromeropsis alacer Howden, 1982: 85

Distribution: Colombia (Bogotá, Valle del Cauca), Ecuador.

References: Howden 1982, 85; Wibmer and O'Brien 1986a, 68; Morrone 1999, 143.

Hadromeropsis annae Anderson, 2008: 65

Distribution: Colombia (Páramo Sumapaz).

References: Anderson 2008, 65.

Hadromeropsis gemmifera (Boheman, 1845: 418)

Distribution: Colombia (Bogotá, Magdalena, Santander), Venezuela; Guatemala, Panama.

References: Boheman in Schönherr 1845, 418 (as Hadromerus gemmifer), Howden 1982, 51 (as Hadromeropsis gemmifer), Wibmer and O'Brien 1986a, 69; Morrone 1999, 144.

\section{Hadromeropsis impressicollis (Kirsch, 1868: 233)}

Distribution: Colombia (Bogotá, Valle del Cauca: Socorro, Boyacá: Muzo).

References: Kirsch 1868, 223 (as Hadromerus impressicollis), Howden 1982, 94; Wibmer and O’Brien 1986a, 69; Morrone 1999, 144.

Hadromeropsis magica (Pascoe, 1881: 41)

Distribution: Brazil (?), Colombia (Bogotá, Cundinamarca (Fusagasugá)).

References: Pascoe 1881, 41 (as Naupactus magicus), Howden 1982, 114 (as Hadromeropsis magicus), Wibmer and O’Brien 1986a, 69; Morrone 1999, 144.

\section{Hadromeropsis mandibularis Howden, 1982: 117}

Distribution: Colombia (St. Antonio (prob. Valle del Cauca)). 
References: Howden 1982, 117; Wibmer and O’Brien 1986a, 69; Morrone 1999, 144.

Hadromeropsis meridiana Howden, 1982: 54

Distribution: Brazil, Colombia (Cundinamarca (Monte Redondo nr. Bogotá, Bogotá, nr. Girardot, Quetame), Tolima (Ibagué)).

References: Howden 1982, 54 (as Hadromeropsis meridianus), Wibmer and O’Brien 1986a, 69; Morrone 1999, 144.

\section{Hadromeropsis nebulicola Howden, 1982: 88}

Distribution: Colombia (Magdalena (San Lorenzo)).

References: Howden 1982, 88 (as Hadromeropsis nebulicolus), Wibmer and O’Brien 1986a, 69; Morrone 1999, 144.

Hadromeropsis pectinata Howden, 1982: 108

Distribution: Bolivia, Colombia, Peru.

References: Howden 1982, 108 (as Hadromeropsis pectinatus), Wibmer and O’Brien 1986a, 69; Morrone 1999, 144.

Hadromeropsis silacea Howden, 1982: 90

Distribution: Brazil (?), Colombia (Antioquia (Frontino), Cauca).

References: Howden 1982, 90 (as Hadromeropsis silaceus), Wibmer and O'Brien 1986a, 69; Morrone 1999, 144.

\section{Hadromeropsis striata Howden, 1982: 126}

Distribution: Colombia [Paso Bella Vista, above Duriamaina].

References: Howden 1982, 126 (as Hadromeropsis striatus), Wibmer and O'Brien 1986a, 69; Morrone 1999, 144.

Genus Macropterus Schönherr, 1840: 419

Distribution: Brazil, Colombia, Peru. 
References: Schönherr 1840b, 419; Wibmer and O'Brien 1986a, 72; AlonsoZarazaga and Lyal 1999, 179; Morrone 1999, 145.

Macropterus chlorostomus Boheman, 1840: 424

Distribution: Brazil, Colombia.

References: Boheman in Schönherr 1840b, 424; Wibmer and O'Brien 1986a, 72; Morrone 1999, 145.

Genus Pandeleteius Schönherr, 1834: 129

Distribution: Argentina, Bolivia, Brazil, Chile, Colombia, Ecuador, Paraguay, Peru, Venezuela; Costa Rica, El Salvador, Guatemala, Honduras, Mexico, Nicaragua, Panama; Dominica, Grenada, Guadeloupe, Jamaica, Saint Vincent; E Canada, USA.

References: Schönherr 1834, 129; Howden 1959, 1974, 1976, 1986, 1996, 1998, 2001, 2004, 2008, 2011, O'Brien and Wibmer 1982, 48; Wibmer and O'Brien 1986a, 69; Alonso-Zarazaga and Lyal 1999, 179; Morrone 1999, 146; Girón and Howden 2019.

\section{Pandeleteius admirabilis Howden, 1976: 192}

Distribution: Colombia (Cauca).

References: Howden 1976, 192; Wibmer and O’Brien 1986a, 69; Morrone 1999, 146.

Pandeleteius andeanus Howden, 1976: 155

Distribution: Colombia (Boyacá (Guateque), Cundinamarca (Guasca-Guachetá, Mesitas del Colegio), Norte de Santander (Chinácota, Pamplona), Valle del Cauca (Palmira)), Venezuela.

References: Howden 1976, 155; Wibmer and O’Brien 1986a, 69; Morrone 1999, 146.

Pandeleteius antiochensis Howden, 1976: 37

Distribution: Colombia (Antioquia (Sonsón)).

References: Howden 1976, 37; Wibmer and O’Brien 1986a, 70; Morrone 1999, 146.

Pandeleteius arcanus Howden, 1876: 60

Distribution: Colombia (?), Venezuela. 
References: Howden 1976, 60, 2004, 193; Wibmer and O’Brien 1986a, 70; Morrone 1999, 146.

Pandeleteius bordoni Howden, 1976: 171

Distribution: Colombia (Norte de Santander (Pamplona)).

References: Howden 1976, 171; Wibmer and O’Brien 1986a, 70; Morrone 1999, 146.

\section{Pandeleteius campbelli Howden, 1976: 104}

Distribution: Colombia (Magdalena (San Lorenzo)).

References: Howden 1976, 104; Wibmer and O’Brien 1986a, 70; Morrone 1999, 146.

Pandeleteius campestris Howden, 1976: 73

Distribution: Colombia (Atlántico (Puerto Colombia), Bolívar (Cartagena, Turbaco), Cesar (Valledupar), Córdoba (Lorica), Magdalena (Río Frío, Sevilla), Sucre (Toluviejo)), Venezuela.

References: Howden 1976, 73, 2004, 207; Wibmer and O'Brien 1986a, 70; Morrone 1999, 146.

\section{Pandeleteius carinipenis Howden, 1976: 123}

Distribution: Colombia (Valle del Cauca (Saladito)).

References: Howden 1976, 123; Wibmer and O’Brien 1986a, 70; Morrone 1999, 146.

Pandeleteius chapini Howden, 1976: 68

Distribution: Colombia (Meta (Restrepo, Villavicencio)), Venezuela.

References: Howden 1976, 68, 2004, 203; Wibmer and O’Brien 1986a, 70; Morrone 1999, 146.

Pandeleteius clivus Howden, 1976: 146

Distribution: Colombia (Cauca (Silvia)).

References: Howden 1976, 146; Wibmer and O’Brien 1986a, 70; Morrone 1999, 146. 
Pandeleteius conirostris Howden, 1976: 101

Distribution: Colombia (Magdalena (San Lorenzo)).

References: Howden 1976, 101; Wibmer and O’Brien 1986a, 70; Morrone 1999, 147.

Pandeleteius dissimilis Voss, 1939: 337

Distribution: Colombia (Candelaria (Valle del Cauca (?))); Costa Rica, Honduras, Panama.

References: Voss 1939, 337; Howden 1976, 185; Wibmer and O’Brien 1986a, 70; Morrone 1999, 147.

Pandeleteius eberhardi Howden, 1976: 135

Distribution: Colombia (Valle del Cauca: Pichindé).

References: Howden 1976, 135; Wibmer and O’Brien 1986a, 70; Morrone 1999, 147.

Pandeleteius excisus Howden, 1976: 169

Distribution: Colombia (Cundinamarca (La Aguadita, Fusagasugá, Silvania, Tequendama)).

References: Howden 1976, 169; Wibmer and O’Brien 1986a, 70; Morrone 1999, 147.

Pandeleteius flavus Howden, 1976: 25

Distribution: Colombia (Valle del Cauca (Cali (Hacienda Arizona, Río Jamundí), Río Pance)).

References: Howden 1976, 25; Wibmer and O’Brien 1986a, 70; Morrone 1999, 147.

\section{Pandeleteius giganteus Howden, 1976: 94}

Distribution: Colombia (Cauca (Silvia)).

References: Howden 1976, 94; Wibmer and O’Brien 1986a, 70; Morrone 1999, 147. 
Pandeleteius hadromeroides (Kirsch, 1868: 234)

Distribution: Colombia ('Bogotá', Cundinamarca (Bogotá, Anolaima, Fusagasugá, Guayabetal, La Aguadita, La Vega, Monte Redondo, Las Tibayes (between Honda and Bogotá), Tena), Quindío (Calarcá)), Venezuela.

References: Kirsch 1868, 234 (as Menetypus hadromeroides), Howden 1976, 149; Wibmer and O’Brien 1986a, 70; Morrone 1999, 147; Solano Rojas and Girón 2019.

Pandeleteius hercules Howden, 1976: 109

Distribution: Colombia (Magdalena (San Lorenzo)), Venezuela.

References: Howden 1976, 109; Wibmer and O’Brien 1986a, 70; Morrone $1999,147$.

Pandeleteius humboldti Howden, 1976: 45

Distribution: Colombia (Cundinamarca (Tequendama, Mosquera, Zipaquirá-Pacho)).

References: Howden 1976, 45; Wibmer and O'Brien 1986a, 70; Morrone 1999, 147.

\section{Pandeleteius minax Dohrn, 1880: 157}

Distribution: Colombia ('Bogotá').

References: Dohrn 1880, 157; Howden 1976, 78, 2004, 209; Wibmer and O’Brien 1986a, 70; Morrone 1999, 148.

\section{Pandeleteius mirirostris Howden, 1976: 23}

Distribution: Colombia (Cundinamarca (Bogotá, Fusagasugá, Melgar, Mesitas del Colegio)).

References: Howden 1976, 23; Wibmer and O'Brien 1986a, 70; Morrone 1999, 148.

Pandeleteius modestus (Faust, 1892: 3)

Distribution: Colombia (Norte de Santander (Santiago)), Venezuela.

References: Faust 1892, 3 (as Menetypus modestus), Howden 1976, 180, 2004, 227; Wibmer and O’Brien 1986a, 70; Morrone 1999, 148. 
Pandeleteius naupactoides (Pascoe, 1881: 38)

Distribution: Brazil, Colombia (Cundinamarca).

References: Pascoe 1881, 38 (as Pandeletius naupactoides), Howden 1976, 119; Wibmer and O'Brien 1986a, 71; Morrone 1999, 148.

Pandeleteius nodifer Champion, 1911: 206

Distribution: Colombia (Bolívar (Cartagena), Cesar (Valledupar), Magdalena (Río Frío, Santa Marta, Sevilla)), Venezuela; Nicaragua, El Salvador; Honduras; Jamaica; SE SW USA.

References: Sharp and Champion 1911, 206; Howden 1970, 46, 1976, 184; Wibmer and O'Brien 1986a, 71; Morrone 1999, 148.

\section{Pandeleteius notabilis Howden, 1976: 128}

Distribution: Colombia (Cauca (Silvia), Galego (Department unknown).

References: Howden 1976, 128; Wibmer and O’Brien 1986a, 71; Morrone 1999, 148.

Pandeleteius novagranadae Howden, 1976: 80

Distribution: Colombia (Norte de Santander (Chinácota, Pamplona)), Venezuela. References: Howden 1976, 80; Wibmer and O’Brien 1986a, 71; Morrone 1999, 148.

\section{Pandeleteius olympus Howden, 1976: 57}

Distribution: Colombia (Cauca (Silvia)).

References: Howden 1976, 57; Wibmer and O’Brien 1986a, 71; Morrone 1999, 148.

Pandeleteius peckorum Howden, 1976: 125

Distribution: Colombia (Norte de Santander (Chinácota), Venezuela.

References: Howden 1976, 125; Wibmer and O’Brien 1986a, 71; Morrone 1999, 148.

Pandeleteius pilosipectus Howden, 1976: 159

Distribution: Colombia (Cundinamarca (Bogotá, Laguna Ubaque)), Ecuador.

References: Howden 1976, 159; Wibmer and O’Brien 1986a, 71; Morrone 1999, 148. 
Pandeleteius procollis Howden, 1976: 84

Distribution: Colombia (Norte de Santander (Quebrada Honda)), Venezuela.

References: Howden 1976, 84; Wibmer and O’Brien 1986a, 71; Morrone 1999, 148.

\section{Pandeleteius pygmaeus Howden, 1976: 70}

Distribution: Colombia (Quindío (Calarcá), Valle del Cauca (Cali (Hacienda La Arizona, Río Jamundí, Río Pance, nr. Pinchindé)).

References: Howden 1976, 70; Wibmer and O’Brien 1986a, 71; Morrone 1999, 148.

\section{Pandeleteius reductus Howden, 1976: 141}

Distribution: Colombia (Antioquia (El Retiro)).

References: Howden 1976, 141; Wibmer and O’Brien 1986a, 71; Morrone 1999, 148.

Pandeleteius regina Howden, 1976: 177

Distribution: Colombia (Cundinamarca (Bogotá, La Unión-Bogotá), Norte de Santander (Pamplona)), Venezuela.

References: Howden 1976, 177; Wibmer and O’Brien 1986a, 71; Morrone 1999, 148.

Pandeleteius santamartae Howden, 1976: 165

Distribution: Colombia (Magdalena (San Lorenzo)).

References: Howden 1976, 165; Wibmer and O’Brien 1986a, 71; Morrone 1999, 148.

Pandeleteius scutellatus Howden, 1976: 97

Distribution: Colombia (Cundinamarca (Bogotá)).

References: Howden 1976, 97; Wibmer and O’Brien 1986a, 71; Morrone 1999, 148.

\section{Pandeleteius separatus Howden, 1976: 51}

Distribution: Colombia (Norte de Santander (Pamplona)).

References: Howden 1976, 51; Wibmer and O'Brien 1986a, 71; Morrone 1999, 148. 
Pandeleteius subtilis Howden, 1996: 887

Distribution: Colombia (Meta (Restrepo)), Peru, Venezuela.

References: Howden 1996, 887; Morrone 1999, 148.

Pandeleteius summus Howden, 1976: 143

Distribution: Colombia (Cauca (Silvia)).

References: Howden 1976, 143; Wibmer and O’Brien 1986a, 71; Morrone 1999, 148.

Pandeleteius tessellatus Howden, 1976: 189

Distribution: Colombia.

References: Howden 1976, 189; Wibmer and O’Brien 1986a, 71; Morrone 1999, 149.

\section{Pandeleteius tinctorius Howden, 1976: 116}

Distribution: Colombia (Cundinamarca (Fusagasugá, Zipaquirá-Pacho)).

References: Howden 1976, 116; Wibmer and O’Brien 1986a, 71; Morrone 1999, 149.

Pandeleteius torquatus Howden, 1976: 62

Distribution: Colombia (Cauca (Silvia)).

References: (Howden 1976, 62; Wibmer and O'Brien 1986a, 71; Morrone 1999, 149.

Pandeleteius truncatus Howden, 1976: 138

Distribution: Colombia (Cauca (Silvia), Valle del Cauca (Cali)).

References: Howden 1976, 138; Wibmer and O’Brien 1986a, 71; Morrone 1999, 149.

\section{Pandeleteius upsilon Howden, 1976: 90}

Distribution: Colombia (Antioquia (Rionegro), Valle del Cauca (Lago Calima)). References: Howden 1976, 90; Wibmer and O’Brien 1986a, 71; Morrone 1999, 149. 
Pandeleteius vitticollis Champion, 1911: 202

Distribution: Colombia (Cundinamarca (Arbeláez, Bogotá, Fusagasugá)); Mexico, Guatemala, Honduras, Nicaragua, Panama.

References: Sharp and Champion 1911, 202; Howden 1976, 162; Wibmer and O’Brien 1986a, 71; Morrone 1999, 149.

\section{Additional comments}

This paper, as a compilation of information, constitutes the first step towards a better understanding of the biodiversity of entimines as a whole in Colombia and northern South America. It also highlights the areas and groups where a lot of work has been done and groups in need of revisionary work.

Due to its geographic location and attributes, Colombia harbours elements of different faunal components of the Americas: Andean, Amazon, Caribbean, Pacific and Orinoco (Ministerio del Medio Ambiente, Departamento Nacional de Planeación, Instituto Alexander von Humboldt 1996). Colombia is in a key position to contribute to the understanding of distributional, ecological and evolutionary patterns of Entiminae across the Americas, but remains as one of the most prominent knowledge gaps in the region for this subfamily and plenty of other insect taxa.

Except for economically-important species, there is a general lack of knowledge about the natural history of Colombian entimines (e.g. host plants, life cycles, natural enemies), which makes it very difficult to understand some of the patterns observed, for instance, the abundance vs. scarcity of some taxa. On the other hand, most entimines in Colombian collections are vegetation dwellers, whereas leaf litter, a highly diverse microhabitat for weevils (e.g. Anderson 2010), is essentially unexplored.

Most revisionary studies in northern South America have yielded numerous new species (Hustache 1938a; Howden 1976; Bordón 1991, 1997). With the notable exception of Howden (1976), not many taxonomic revisions of Neotropical entimines have included Colombian specimens; many of the specimens studied by Howden were collected directly by her and her colleagues in the early 1970s (Howden 1976). In the few recent revisions including Colombian material, examined specimens are housed in international collections and collected by early researchers in the times of "Nova Granada" (e.g. del Río and Lanteri 2007a, for Melanocyphus). This highlights a major issue for advancing the knowledge of Colombian entomofauna, in general: access to Colombian specimens by researchers is greatly limited. This fact, in turn, highlights other problems: (1) type material or even specimens correctly identified to species are extremely scarce (or non-existent) in national collections; (2) national experts (in Curculionidae), who would potentially be able to study type material abroad, are even more scarce, considering the high diversity of the group in the country (see Girón and Cardona-Duque 2018); (3) international experts essentially have no access to recent Colombian specimens, unless they visit Colombian national collections, which may not always be feasible; and, even if international researchers are able to visit, (4) national regulations make it very difficult to borrow specimens to take them out of the 
country for study. All of these issues combined, call for creating or strengthening international collaborations and adapting regulations to allow specimen exchange.

The good news is that digitisation efforts in libraries, and both in national and international biological collections, are contributing to improved access to specimens, data and expertise. Platforms, such as Biodiversity Heritage Library (https://www. biodiversitylibrary.org/), provide access to publications of original descriptions, museums are digitising their collections (entering data and imaging specimens, including types; for example, The Natural History Museum in London, (https:// data.nhm.ac.uk/search/entomology) and $\mathrm{SiB}$ Colombia (https://sibcolombia.net/; https://colecciones.biodiversidad.co/) is providing access to specimen data from national collections. In addition, platforms, like iNaturalist (https://www.inaturalist. org/home), are continuously generating records for Colombian species. The greatest limitation to learning and understanding Colombian biodiversity is the availability of national experts who are able to study specimens both in national and international collections. Identifiying entimines in Colombia is still a challenging task. Some of the specimens recorded here remain identified only to subfamily (Fig. 11) and are presented here in the hope that those can be revised and determined in the future, especially those from scarcely-explored regions.

Even though this work does not include all the entomological collections in the country and many remain to be revised, each collection revised here harbours a very unique diversity. It is evident that there is collecting bias towards the Andean region, with all other regions, but specially Amazon, Caribbean, Orinoco and the Islands (both Caribbean and Pacific), which are potentially as rich in diversity of species, poorly sampled sampled (see maps in Figs 2-11). The distribution of many species within the country is still to be determined: about one third of the species remain simply recorded from "Colombia" and about another third have been described from specimens collected in 'Bogotá' of the 1800s to early 1900s. Studying entimines in national collections and collecting them in poorly sampled regions will likely produce new records and taxa new to science all across the country.

\section{Acknowledgements}

The production of this contribution started in 2006 as part of my undergraduate research project; at the time, guidance by Nancy Carrejo and support by Carmen Elisa Posso (MUSENUV) and the Grupo de Investigaciones Entomológicas (Departamento de Biología, Facultad de Ciencias, Universidad del Valle, Cali, Colombia) were fundamental for the development of the project. Robert Anderson has been extremely helpful in my career studying broad-nosed weevils: he provided identifications, literature, advice and encouragement during the early development of this work and for that, I will be eternally grateful. I'm in debt to Collections' curators, managers and assistants who provided access to specimens and on-site equipment: Claudia Alejandra Medina Uribe and Fabio Arturo Gonzalez Alvarado (at IAvH), Dimitri Forero and José Manuel Ramírez Salamanca (at MPUJ). Juliana Cardona-Duque has supported this contribution in many significant ways, providing data from CEUA and MEPB, 
georeferencing all entimine records, revising and editing earlier versions of this manuscript and overall keeping me convinced that getting this compilation of information out in the world is valuable. Analía Lanteri has provided invaluable and critical feedback on several versions of this contribution over the years; thanks to her, the content of this document is much more accurate and comprehensive. The late Charles O'Brien and Nico Franz contributed their expertise, access to specimens and literature and encouragement at several points during the development of this work. Juan José Morrone also provided feedback and encouragement as a reviewer of the very first version of this manuscript, back in 2007. Alexander Ortiz facilitated the initial production of line-drawings. Ivon Babativa assisted databasing specimens at $\mathrm{IAvH}$. My main motivation in producing this manuscript is to make information accessible and easy to find. It has taken me years to become familiar with literature about Colombian entimines and nowadays, I have the bibliographic resources, but living overseas, no access to Colombian specimens. I would like young researchers in Colombia to be able to quickly find information and to study entimine specimens right away! Many of the resources referenced here are available via The Biodiversity Heritage Library (https://www.biodiversitylibrary.org/), for which I'm also very grateful.

\section{References}

Alcalá P, Alcázar J (1976) Biología y comportamiento de Premnotrypes suturicallus Kuschel (Col. Curculionidae). Revista Peruana de Entomología 19: 49-52. https://sisbib.unmsm. edu.pe/BVRevistas/entomologia/v19/pdf/a10v19.pdf

Alcázar J, Cisneros F (1998) Taxonomy and bionomics of the Andean Potato Weevil Complex: Premnotrypes spp., and related genera. Impact on a changing world: Program Report 1997-98. International Potato Center, 141-151. https://books.google.com/ books?id=aWwV1Pv8_cUC\&pg=PA141\&\#v=onepage\&q\&f=false

Alonso-Zarazaga MA, Lyal CHC (1999) A world catalogue of families and genera of Curculionoidea (Insecta: Coleoptera) excluding Scolytidae and Platypodidae. Entomopraxis, Barcelona, Spain, 315 pp.

Anderson RS (1993) Weevils and plants: Phylogenetic versus ecological mediation of evolution of host plant associations in Curculioninae (Coleoptera: Curculionidae). Memoirs of the Entomological Society of Canada 125(S165): 197-232. https://doi.org/10.4039/ entm125165197-1

Anderson RS (2008) A new species of flightless Hadromeropsis from the Colombian páramo (Coleoptera: Curculionidae; Entiminae; Tanymecini). Zootaxa 1879(1): 65-68. https:// doi.org/10.11646/zootaxa.1879.1.8

Anderson RS (2010) A taxonomic monograph of the Middle American leaf-litter inhabiting weevil genus Theognete Champion (Coleoptera: Curculionidae; Molytinae; Lymantini). Zootaxa 2458(1): 1-127. https://doi.org/10.11646/zootaxa.2458.1.1

Anderson RS (2018) 2.2.6. Weevil habitat associations and host evolution/coevolution. In: Morphological and molecular perspectives on the phylogeny, evolution, and classification of weevils (Coleoptera: Curculionoidea): Proceedings from the 2016 International Weevil Meeting. Diversity (Basel) 10(3): e64. https://doi.org/10.3390/d10030064 
Anderson RS, Howden AT (2002) 131 Curculionidae Latreille 1802. American Beetles, Volume II: Polyphaga: Scarabaeoidea through Curculionoidea. CRC Press, Boca Raton, 722-815. Anderson RS, Lanteri AA (2000) New genera and species of weevils from the Galapagos Islands, Ecuador, and Cocos Island, Costa Rica (Coleoptera; Curculionidae; Entiminae; Entimini). American Museum Novitates 2000: 1-15. https://doi.org/10.1206/00030082(2000)299\%3C0001:NGASOW\%3E2.0.CO;2

Araujo FE, Cavalcante RD, Cavalcante MLS, Melo QMS (1977) Hypsonotus sp. (Col. Curculionidae) attacking groundnut (Arachis hypogaea L.) in the State of Ceara, Brazil. Fitossanidade 2: 47. https://agris.fao.org/agris-search/search.do?recordID=BR19780310907

Boisduval JBA (1835) Voyage de découvertes de L’Astrolabe exécuté par ordre du Roi, pendant les annies 1826-1827-1828-1829, sous le commandement de M.J. Dumont d'Urville. Faune Entomologique de l'Océan Pacifique, avec illustration des insectes nouveaux recueillis pendant le voyage. Deuxième partie. Coléoptères et autres ordres. J. Tatsu, Paris, [VII +] 716 pp. https://doi.org/10.5962/bhl.title.35819

Bordón C (1991) El género Macrostylus Boheman (Col. Curc. Brachyderinae, Naupactini) en Venezuela. Acta Biológica Venezuélica 13(1-2): 1-50.

Bordón C (1997) El género Naupactus Dejean (Coleoptera: Curculionidae) en Venezuela. Acta Biológica Venezuélica 17(2): 11-51.

Bouchard P, Bousquet Y, Davies A, Alonso-Zarazaga M, Alonso-Zarazaga M, Lawrence J, Lyal C, Newton A, Reid C, Schmitt M, Slipinski A, Smith A (2011) Family-group names in Coleoptera (Insecta). ZooKeys 88: 1-972. https://doi.org/10.3897/zookeys.88.807

Bovie A (1908a) Coleoptera. Fam. Curculionidae. Subfam. Entiminae. Genera Insectorum, 1-7. [+ 1.] https://biodiversitylibrary.org/page/33734015

Bovie A (1908b) Notes sur les Curculionides. Annales de la Société entomologique de Belgique 52: 43-44. https://doi.org/10.5962/bhl.part.5001

Bruch C (1932) Metamorfosis de Entimus nobilis Oliv. (Coleopt., Curculionidae). Revista de Etología 2: 179-185.

Bustillo AE, Villegas Isaza MC (1986) El picudito del aliso Bothynodontes sp. (Coleoptera: Curculionidae) nueva plaga de forestales en Caldas. Apuntes entomológicos 2: 1-3.

Calvache G (1987) Capture of adults of Premnotrypes vorax (Hustache) with adults of the same species as attractant. Revista Colombiana de Entomología 11(2): 9-14. https://doi. org/10.25100/socolen.v11i2.10258

Canchala MB (1992) Estudios biológicos de Naupactus sp. Coleoptera: Curculionidae. Nueva plaga en Nariño. Universidad de Nariño, Facultad de Ciencias Agrícolas.

Cano DM, Serna FJ, Bustillo AE (2002a) Características anatómicas de una nueva especie de Compsus (Coleoptera: Curculionidae) plaga de cítricos en Colombia. Revista Colombiana de Entomología 28(1): 33-41. https://doi.org/10.25100/socolen.v28i1.9626

Cano DM, Bustillo AE, Cárdenas R, Orozco L (2002b) Biología y enemigos nativos del picudo de los cítricos Compsus n. sp. (Coleoptera: Curculionidae). Revista Colombiana de Entomología 28(1): 43-52. https://doi.org/10.25100/socolen.v28i1.9627

Cardona-Duque J, Bota-Sierra CA, Correa-Carmona Y, Flórez C, Girón JC, Vélez-Bravo A, Wolff M (2018) Estado del conocimiento de insectos en los Bosques Andinos de Antioquia. In: Quintero-Vallejo E, Benavides AM, Moreno N, González-Caro S (Eds) Bosques Andinos, estado actual y retos para su conservación en Antioquia. Fundación 
Jardín Botánico de Medellín Joaquín Antonio Uribe Programa Bosques Andinos (COSUDE), Medellín, Colombia, 241-266. http://www.observatoriobosquesantioquia.org/ Libro-Bosques-Andinos

Chevrolat LAA (1877) Descriptions de Curculionides nouveaux. Annales de la Société Entomologique de France 5(7): 170-173. https://www.biodiversitylibrary.org/page/8244498

Chevrolat LAA (1878) Descriptions de quatre Curculionides nouveaux, dont l'un est le type d'un genre nouveau dans le groupe des Megalostylus. Annales de la Société entomologique de France, Bulletin des Séances: LIV-LV. https://biodiversitylibrary.org/page/8233114

Chevrolat LAA (1879) Diagnoses de nouvelles espèces de la famille des Curculionides. Annales de la Société entomologique de France, Bulletin des Séances: LXXVII-LXXVIII. https://biodiversitylibrary.org/page/8250753

Chevrolat LAA (1881) Fait connaître quatre nouvelles espèces américaines de Curculionites. Annales de la Société entomologique de France, Bulletin des Séances 6: XXXIII. https:// gallica.bnf.fr/ark:/12148/bpt6k6335721w/f588.image

Cortázar Gómez JE, López-Pazos SA, Cerón J (2012) Determination of Cry toxin activity and identification of an aminopeptidase $\mathrm{N}$ receptor-like gene in Asymmathetes vulcanorum (Coleoptera: Curculionidae). Journal of Invertebrate Pathology 111(1): 94-98. https://doi.org/10.1016/j.jip.2012.06.003

Cortés-Hernández KA, Anderson RS (2019) Two new species of Isodrusus Sharp, 1911 (Coleoptera: Curculionidae: Entiminae: Tanymecini). The Coleopterists Bulletin 73(4): 940-944. https://doi.org/10.1649/0010-065X-73.4.940

Cortés-Hernández KA, Morrone JJ (2019) A key to the Mexican genera of Tanymecini (Coleoptera: Curculionidae). Zootaxa 4615(1): 46-56. https://doi.org/10.11646/zootaxa.4615.1.2

Cortés-Hernández KA, Morrone JJ (2020) Systematic revision of the genus Isodacrys Sharp, 1911 (Coleoptera: Curculionidae: Entiminae: Tanymecini). PeerJ 8: e10191. https://doi. org/10.7717/peerj.10191

Dejean PFMA (1821) Catalogue des Coléoptères de la collection de M. le Baron Dejean. Chez Crevot, Librairie, Paris, 136 pp. https://doi.org/10.5962/bhl.title.11259

del Río MG, Lanteri AA (2007a) Taxonomic revision of Melanocyphus Jekel (Coleoptera: Curculionidae). Studies on Neotropical Fauna and Environment 42(2): 127-132. https:// doi.org/10.1080/01650520601102567

del Río MG, Lanteri AA (2007b) Thoraconaupactus, a new Brazilian genus of broad nosed weevil (Coleoptera: Curculionidae: Entiminae) associated with Leucaena (Fabaceae). Entomological News 118(5): 459-469. https://doi.org/10.3157/0013-872X(2007)118[4 59:TANBGO]2.0.CO;2

del Río MG, Lanteri AA (2011a) Obrieniolus, a new monotypic genus of Naupactini (Coleoptera, Curculionidae, Entiminae) from the Peruvian Andes and its phylogenetic placement. ZooKeys 102: 51-60. https://doi.org/10.3897/zookeys.102.1240

del Río MG, Lanteri AA (2011b) Taxonomic revision of the genus Hadropus Schoenherr (Coleoptera: Curculionidae) with comments on infraspecific variation. Transactions of the American Entomological Society 137: 307-315. https://doi.org/10.3157/061.137.0304

del Río MG, Lanteri AA (2012) Redescription of the genus Curiades Pascoe 1880 (Coleoptera: Curculionidae: Entiminae: Naupactini), a potential mimic of Mutillidae from Brazil. Zootaxa 3570(1): 82-88. https://doi.org/10.11646/zootaxa.3570.1.6 
del Río MG, Lanteri AA (2013) Taxonomic revision of the genus Stenocyphus Marshall (Coleoptera, Curculionidae) from Brazil. ZooKeys 357: 29-43. https://doi.org/10.3897/ zookeys.357.5854

del Río MG, Lanteri AA (2018) New synonymies, new combinations and lectotype designations for weevils in the tribe Naupactini (Coleoptera: Curculionidae: Entiminae). Zootaxa 4500(3): 329-340. https://doi.org/10.11646/zootaxa.4500.3.2

del Río MG, Lanteri AA (2019) Recognition of species groups of Naupactus Dejean (Coleoptera: Curculionidae) from Argentina and neighboring countries. PeerJ 6: e6196. https://doi.org/10.7717/peerj.6196

del Río MG, Lanteri AA (2020) A new enigmatic species of broad-nosed weevil endemic to Brazil and its phylogenetic placement within the tribe Naupactini (Coleoptera: Curculionidae: Entiminae). Papéis Avulsos de Zoologia 60(special): e202060(s.i.).30. https:// doi.org/10.11606/1807-0205/2020.60.special-issue.30

del Río MG, Lanteri AA, Guedes JVC (2006) Taxonomic revision and cladistic analysis of Teratopactus Heller (Coleoptera: Curculionidae). Invertebrate Systematics 20(5): 585-602. https://doi.org/10.1071/IS05047

del Río MG, Malvardi AE, Lanteri AA (2012) Systematics and cladistics of a new Naupactini genus (Coleoptera: Curculionidae: Entiminae) from the Andes of Colombia and Ecuador. Zoological Journal of the Linnean Society 166(1): 54-71. https://doi.org/10.1111/ j.1096-3642.2012.00833.x

del Río MG, Morrone JJ, Lanteri AA (2015) Evolutionary biogeography of South American weevils of the tribe Naupactini (Coleoptera: Curculionidae). Journal of Biogeography 42(7): 1293-1304. https://doi.org/10.1111/jbi.12481

del Río MG, Rodriguero MS, Confalonieri VA, Lanteri AA (2018) Molecular and morphological phylogenetic analysis of Naupactus Dejean (Curculionidae: Entiminae) and allied genera: the dilemma of classification. Diversity (Basel) 10(3): e59. https://doi. org/10.3390/d10030059

Dohrn CA (1880) Exotisches. Entomologische Zeitung 41: 149-157. https://biodiversitylibrary.org/page/8989523

Dueñas IOT (1989) Ciclo biológico de Premnotrypes latithorax, bajo condiciones de laboratorio, en el Cusco. Revista Peruana de Entolomogía 32: 89-92.

Evenhuis NL (2020) The Insect and Spider Collections of the World Website. http://hbs. bishopmuseum.org/codens/

Fabricius JC (1787) 1 Mantissa insectorum sistens eorum species nuper detectas adiectis characteribus genericis, differentiis specifis, emendationubus, observationibus. Hafniae, [XX +] 348 pp. https://doi.org/10.5962/bhl.title.11657

Faust J (1892) Reise von E. Simon in Venezuela. Curculionidae. Pars prima. Stettiner Entomologische Zeitung 53: 1-44. https://biodiversitylibrary.org/page/9266298

Faust J (1893) Neue Helipinen. Stettiner Entomologische Zeitung 54: 3-15. https://www. biodiversitylibrary.org/page/8932093

Faust J (1894) Beriehtigung. Stettiner Entomologische Zeitung 54: 368. https://babel.hathitrust.org/cgi/pt?id=uiug.30112077164264\&view=1 up\&seq=374

Fischer de Waldheim G (1829) Museum Historiae Naturalis Universitatis Caesareae Mosquensis. Pars II. Insecta. Typis Universitatis Caesareae, Mosquae, 147 pp. 
Forster JR (1771) Novae species insectorum: Centuria I. T. Davies, B. White, 100 pp. https:// doi.org/10.5962/bhl.title.152194

Franz NM (2010a) Redescriptions of critical type species in the Eustylini Lacordaire (Coleoptera: Curculionidae: Entiminae). Journal of Natural History 44(1-2): 41-80. https:// doi.org/10.1080/00222930903383495

Franz NM (2010b) Revision and phylogeny of the Caribbean weevil genus Apotomoderes Dejean, 1834 (Coleoptera, Curculionidae, Entiminae). ZooKeys 49: 33-75. https://doi. org/10.3897/zookeys.49.303

Franz NM (2011) Melathra huyenae Franz, a new genus and new species of Entimine Weevil (Coleoptera: Curculionidae: Entiminae) from Southwestern Hispaniola. The Coleopterists Bulletin 65(4): 352-362. https://doi.org/10.1649/072.065.0406

Franz NM (2012) Phylogenetic reassessment of the Exophthalmus genus complex (Curculionidae: Entiminae: Eustylini, Geonemini). Zoological Journal of the Linnean Society 164(3): 510-557. https://doi.org/10.1111/j.1096-3642.2011.00774.x

Franz NM, Girón JC (2009) Scelianoma elydimorpha, a new genus and new species of entimine weevil from southwestern Puerto Rico (Coleoptera: Curculionidae, Entiminae). Neotropical Entomology 38(2): 219-230. https://doi.org/10.1590/S1519-566X2009000200009

Gaiger F (2001) Systematic revision and cladistic analysis of the genus Rhigus Schoenherr, 1823 (Coleoptera, Curculionidae). Revista Brasileira de Entomologia 45: 43-85.

Gallego JS, Caicedo AM, Carabalí A, Muñoz JE (2012) Comportamiento alimenticio y de oviposición de Compsus viridivittatus (Coleoptera: Curculionidae) en especies de cítricos. Revista Colombiana de Entomología 38: 191-195. http://www.scielo.org.co/scielo. php?script=sci_abstract\&pid=S0120-04882012000200005\&lng=en\&nrm=iso\&tlng=es

Gemmiger M, von Harold E (1871) Catalogus coleopterorum hucusque descriptorum synonymicus et systematicus (Vol. 8). Curculionidae. Gummi, Monachii, 2181-2668. https://www.biodiversitylibrary.org/page/9649110

Germar EF (1817) (Note) in Miscellen und Correspondenz-Nachrichten. Magazine der Entomologie 2: 339-341. https://www.biodiversitylibrary.org/page/25412901

Germar EF (1824) Insectorum species novae aut minus cognitae, descriptionibus illustratae (Vol. 1). Coleoptera. J. C. Hendelii et filii, Halae, [xxiv +] 624 pp. [+2 pl.] https://doi. org/10.5962/bhl.title.130964

Germar EF (1829) Curculionides. Allgemeine Encyclopädie der Wissenschaften und Künste, Zwanzigster Theil. Johann Friedrich Oledifch, Leipzig, 356-359. https://babel.hathitrust.org/cgi/pt?id=umn.31951002385839g\&view=1 up\&seq=78

Gillett CPDT, Barr I (2020) First record of the entimine weevil genus Rhigus Schoenherr, 1823 (Coleoptera: Curculionidae: Entiminae: Entimini) in Peru: Rhigus speciosus (Linnaeus, 1758) in Madre de Dios. The Coleopterists Bulletin 74(1): 195-196. https://doi. org/10.1649/0010-065X-74.1.195

Girón JC (2006) A note on Colombian Entiminae. Curculio 52: 6-7. https://www.coleopsoc. org/wp-content/uploads/2018/05/curculio_52.pdf

Girón JC (2007a) Estudio de los Entiminae (Coleoptera: Curculionidae) depositados en el Museo de Entomología de la Universidad del Valle. Undergrad honors thesis abstract. Boletín del Museo de Entomología de la Universidad del Valle 8: 1-34. https://drive. google.com/file/d/1OZMUW9vzydpFcfmudCo2pJWAFKps80dA/view 
Girón JC (2007b) Estudio de los Entiminae (Coleoptera: Curculionidae) depositados en el Museo de Entomología de la Universidad del Valle. Undergrad honors thesis abstract. Undergrad. Universidad del Valle.

Girón JC (2020) Listado de las especies de Entiminae (Coleoptera: Curculionidae) de Colombia. Grupo de Coleopterólogos de Colombia. Checklist dataset. https://doi. org/10.15472/jdwfao [accessed via GBIF.org on 2020-12-01]

Girón JC, Cardona-Duque J (2018) Estado del conocimiento de los Curculionidae en Colombia. In: Deloya C, Gasca Álvarez HJ (Eds) Escarabajos del Neotrópico (Insecta: Coleoptera). S y G editores, Mexico, 167-199.

Girón JC, Chamorro ML (2020) Variability and distribution of the golden-headed weevil Compsus auricephalus (Say) (Curculionidae: Entiminae: Eustylini). Biodiversity Data Journal 8: e55474. https://doi.org/10.3897/BDJ.8.e55474

Girón JC, Franz NM (2010) Revision, phylogeny and historical biogeography of the genus Apodrosus Marshall, 1922 (Coleoptera: Curculionidae: Entiminae). Insect Systematics \& Evolution 41(4): 339-414. https://doi.org/10.1163/187631210X538799

Girón JC, Franz NM (2012) Phylogenetic assessment of the Caribbean weevil genus Lachnopus Schoenherr (Coleoptera: Curculionidae: Entiminae). Invertebrate Systematics 26(1): 67-82. https://doi.org/10.1071/IS11033

Girón JC, Howden AT (2019) Five new species of Pandeleteius Schönherr, 1834 (Coleoptera: Curculionidae: Entiminae: Tanymecini) from South America. The Coleopterists Bulletin 73(4): 831-845. https://doi.org/10.1649/0010-065X-73.4.831

Girón JC, O’Brien CW, Rose-Smyth MC (2018) On the West Indian weevil genus Lachnopus Schönherr, 1840 (Coleoptera: Curculionidae: Entiminae): Descriptions of six new species, a proposal for species-groups, and an annotated checklist. Zootaxa 4423(1): 1-85. https://doi.org/10.11646/zootaxa.4423.1.1

Gistel J (1856) Die Mysterien der Europäischen Insectenwelt. Druck und Verlag von Tobias Dannheimer, Kempten, 544 pp. https://biodiversitylibrary.org/page/42180002

Guérin-Méneville FE (1855) Catalogue des insectes coléoptères recueillis par M. Gaetano Osculati, pendant son exploration de la région équatoriale, sur les bords du Napo et de l'Amazone. Verhandlungen des Zoologisch-Botanischen Vereins in Wien 5: 573-612. https://biodiversitylibrary.org/page/12049594

Guzmán NV, Lanteri AA, Confalonieri VA (2012) Colonization ability of two invasive weevils with different reproductive modes. Evolutionary Ecology 26(6): 1371-1390. https:// doi.org/10.1007/s10682-012-9564-4

Háva J, Rukmane A (2018) Short contribution to the genus Pachyrhynchus from the Philippines (Coleoptera: Curculionidae: Pachyrhynchini). Acta Biologica Universitatis Daugavpiliensis 18: 203-205. http://sciences.lv/wp-content/uploads/2019/01/ H\%C3\%A1va_218_2.pdf

Howden AT (1959) A revision of the species of Pandeleteius Schonherr and Pandeleteinus Champion of America north of Mexico (Coleoptera: Curculionidae). Proceedings of the California Academy of Sciences 29: 361-421. https://biodiversitylibrary.org/ page/15657419

Howden AT (1961) A revision of the genus Isodacrys Sharp (Curculionidae, Tanymecini). The Coleopterists Bulletin 15: 75-95. https://www.jstor.org/stable/3998942 
Howden AT (1963) A new species of Isodrusus, with notes on Isodrusus debilis Sharp (Coleoptera: Curculionidae: Tanymecini). The Coleopterists Bulletin 17(2): 43-46. https:// www.jstor.org/stable/3999156

Howden AT (1966) Airosimus, a new genus of Neotropical Tanymecini (Coleoptera: Curculionidae). Transactions of the American Entomological Society 92: 173-229. https:// www.jstor.org/stable/25077915

Howden AT (1969) The genus Pandeleteinus Champion with the description of a new species from Mexico (Curculionidae, Tanymecini). The Coleopterists Bulletin 23: 76-83. https://www.jstor.org/stable/3999503

Howden AT (1970) The Tanymecini of the West Indies (Coleoptera: Curculionidae). Contributions of the American Entomological Institute 5: 1-73.

Howden AT (1974) The Pandeleteius subgenus Exmenetypus Voss in Central America (Coleoptera: Curculionidae, Tanymecini). The Coleopterists Bulletin 28: 7-16. https://www. jstor.org/stable/3999528

Howden AT (1976) Pandeleteius of Venezuela and Colombia (Curculionidae: Brachyderinae: Tanymecini). Memoirs of the American Entomological Institute 24: 1-310.

Howden AT (1982) Revision of the New World genus Hadromeropsis Pierce (Coleoptera, Curculionidae, Tanymecini). Contributions of the American Entomological Institute 19: 1-180.

Howden AT (1986) The Pandeleteius armatus group, with description of a new species from Mexico (Coleoptera: Curculionidae). The Coleopterists Bulletin 40: 317-323. https:// www.jstor.org/stable/4008295

Howden AT (1993) Revision of the Mesoamerican species of Airosimus Howden (Coleoptera: Curculionidae). The Coleopterists Bulletin 47: 249-267. https://www.jstor.org/stable/4009017

Howden AT (1996) Neotropical Pandeleteius (Coleoptera: Curculionidae) with irregular elytral striae. The Canadian Entomologist 128(5): 877-955. https://doi.org/10.4039/Ent128877-5

Howden AT (1998) Review of the Pandeleteius biseriatus species-group (Coleoptera: Curculionidae), with description of a new species. The Canadian Entomologist 130(3): 367-375. https://doi.org/10.4039/Ent130367-3

Howden AT (2001) A new species of Pandeleteius from Peru (Coleoptera, Curculionidae). Revue Française d'Entomologie (N. S.) 23: 171-175.

Howden AT (2004) Review of the genus Pandeleteius (Coleoptera: Curculionidae) of northern South America and the Lesser Antilles. The Canadian Entomologist 136(2): 181-231. https://doi.org/10.4039/n03-075

Howden AT (2008) The species of Pandeleteius Schoenherr of coastal Chile and Peru (Coleoptera, Curculionidae). Zootaxa 1773(1): 55-62. https://doi.org/10.11646/zootaxa.1773.1.5

Howden AT (2011) On some species of Pandeleteius Schoenherr, 1834, in South America south of the tenth parallel (Coleoptera, Curculionidae: Entiminae: Tanymecini). Zootaxa 2977(1): 50-60. https://doi.org/10.11646/zootaxa.2977.1.2

Hustache A (1933) Deux nouveaux curculionides déprédateurs. Bulletin du Muséum National d'Histoire Naturelle 2: 376-380. https://biodiversitylibrary.org/page/52068095

Hustache A (1938a) Compsus sud-américains (Coleoptera Curculionidae). Bulletin de la Société Entomologique de Belgique 78: 67-118. 
Hustache A (1938b) Curculionides noveaux de l’Amérique méridionale, qui se trovent dans le Deutsches Entomologisches Institut. Deuxième note. Arbeiten über morphologische und taxonomische Entomologie aus Berlin-Dahlem 5: 265-288.

Hustache A (1946) Deux curculionides nouveaux de l'Amérique du Sud. Bulletin Mensuel de la Societe Linneenne de Lyon 15(1): 3-6. https://doi.org/10.3406/linly.1946.8222

Jekel H (1854) Fabricia Entomologica. recueil d’observations nouvelles sur les insectes; monographies, révisions de groupes et de genres, classifications, synonymies et rectifications, decriptions de genres nouveaux et d'espèces nouvelles. https://doi.org/10.5962/bhl.title.66012

Jekel H (1857) Fabricia Entomologica. recueil d'observations nouvelles sur les insectes; monographies, révisions de groupes et de genres, classifications, synonymies et rectifications, decriptions de genres nouveaux et d'espèces nouvelles. Part 1: 97-184. https:// biodiversitylibrary.org/page/42184434

Jekel H (1858) Spicilegia Entomologica II: Descriptions of new Curculionidous beetles collectedon the voyage of H. M. S. Herald. Annals \& Magazine of Natural History 3: 356-351. https://www.biodiversitylibrary.org/page/18659257

Jekel H (1859) Fabricia Entomologica. recueil d'observations nouvelles sur les insectes; monographies, révisions de groupes et de genres, classifications, synonymies et rectifications, decriptions de genres nouveaux et d'espèces nouvelles. Part 1. 3e Livraison: 185-249. https://biodiversitylibrary.org/page/42184434

Jekel H (1875) Coleoptera Jekeliana adjecta eleutheratorum bibliotheca. Énumération systématique et synonymique des coléoptères européens et exotiques composant la collection de Henri Jekel, observations critiques, description d'espèces nouvelles, reproduction et traduction de genres et espèces publiés dans des ouvrages rares français et étrangers de manière à former insensiblement la Bibliotheque du Coleoptériste. Librairie Zoologique de E. Deyrolle fils, Paris. https://gallica.bnf.fr/ark:/12148/bpt6k884758k/f5.image

Kessel F (1932) Fauna Brasiliensis Coleopterologica. Lieferung 1. Friedländer \& Sohn, Berlin, 1-32.

Kessel F (1935) Fauna Brasiliensis Coleopterologica. Lieferung 3. Friedländer \& Sohn, Berlin, 73-113.

Kessel F (1937) Fauna Brasiliensis Coleopterologica. Lieferung 4. Friedländer \& Sohn, Berlin, 114-184.

Kirsch T (1868) Beiträge zur Käferfauna von Bogotà. (Drittes Stück: Brenthiden und adelognathe Curculionen). Berliner Entomologische Zeitschrift 11(3-4): 215-243. https:// biodiversitylibrary.org/page/9215483

Kirsch T (1889) Coleopteren gesammelt in den Jahren 1868-1877 auf einer Reise durch Süd Amerika von Alphons Stübel. Abhandlungen und Berichte des Königl. Zoologischen und Anthropologisch-Etnographischen Museums zu Dresden. 1888-1889: 1-58. [+ 4 pt] https://www.biodiversitylibrary.org/page/33470151

Kuschel G (1955a) Compsus serrans n. sp., gorgojo dañino de la caña de azúcar en Venezuela (Aporte 20 de Coleoptera, Curculionidae). Boletín de Entomología Venezolana 11: 1-8. Kuschel G (1955b) Nuevas sinonimias y anotaciones sobre Curculionoidea. Revista Chilena de Entomología 4: 261-312. http://www.insectachile.cl/rchen/pdfs/1955v04/ Kuschel_1955b.pdf 
Kuschel G (1956) Revision de los Premnotrypini y adiciones a los Bagoini. Boletín del Museo Nacional de Historia Natural 26: 187-235. http://publicaciones.mnhn.gob.cl/668/ articles-63959_archivo_01.pdf

Lacordaire JT (1863) Histoire naturelle des insectes: Genera des Coléoptères ou exposé méthodique et critique de tous les genres proposés jusqu'ici dans cet ordre d'insectes. Tome Sexième. Contenant la famille des Curculionides. Librairie encyclopédique de Roret, Paris, 637 pp. https://biodiversitylibrary.org/page/9375856

Lanteri AA (1980) Contribución al conocimiento del género Eurymetopus Schönherr (Coleoptera, Curculionidae). I- Redescripción del género Eurymetopus Schönherr y su estudio comparativo con Floresianus Hustache y Floresianellus Hustache. Revista de la Sociedad Entomológica Argentina 39(3-4): 263-269. https://www.biotaxa.org/RSEA/article/view/40838

Lanteri AA (1982) Estudio taxonómico del género Wagneriella Hustache (Coleoptera, Curculionidae). Revista de la Sociedad Entomológica Argentina 41(1-4): 61-76. https:// www.biotaxa.org/RSEA/article/view/40435

Lanteri AA (1984) Revisión sistemática del género Eurymetopus Schoenherr (Coleoptera, Curculionidae) mediante la aplicación de técnicas numéricas. Revista de la Sociedad Entomológica Argentina 43(1-4): 247-281. https://www.biotaxa.org/RSEA/article/view/36972

Lanteri AA (1985) Revisión de las especies argentinas del género Macrostylus, subgénero Mimographus Schoenherr (Coleoptera, Curculionidae). CIPFE-CED Orione Contribuciones en Biología 12: 1-6.

Lanteri AA (1986) Revisión del Género Asynonychus Crotch (Coleoptera: Curculionidae). Revista de la Asociacion de Ciencias Naturales del Litoral 17: 161-174. https://doi. org/10.14409/natura.v2i17.3496

Lanteri AA (1989) Estudio sistemático de los géneros Trichocyphus Heller y Mendozella Hustache (Coleoptera: Curculionidae). Boletín de la Sociedad de Biología de Concepción 60: 139-147. https://www.biodiversitylibrary.org/page/31654685

Lanteri AA (1990a) Revisión sistemática del género Cyrtomon Schönherr (Coleoptera, Curculionidae). Revista Brasileira de Entomologia 34: 387-402.

Lanteri AA (1990b) Revisión sistemática del género Priocyphus Hustache 1939 y creación de los géneros Priocyphopsis y Lamprocyphopsis (Coleoptera, Curculionidae). Revista Brasileira de Entomologia 34: 403-422.

Lanteri AA (1990c) Revisión sistemática y análisis filogenético de las especies del género Enoplopactus Heller 1921 (Coleoptera, Curculionidae). Boletín de la Sociedad de Biología de Concepción 61: 71-92. https://biodiversitylibrary.org/page/31654879

Lanteri AA (1990d) Systematic revision and cladistic analysis of Phacepholis Horn. Southwestern Entomologist 15: 179-204. http://agrilife.org/sswe/files/2017/04/SWE_V15.pdf

Lanteri AA (1992) Systematics, cladistics and biogeography of a new weevil genus, Galapaganus (Coleoptera: Curculionidae) from the Galápagos Islands, and coasts of Ecuador and Perú. Transactions of the American Entomological Society 118: 227-267. https:// www.jstor.org/stable/25078560

Lanteri AA (1995) Systematic revision of Ericydeus Pascoe (Coleoptera: Curculionidae). Entomologica Scandinavica 26(4): 393-424. https://doi.org/10.1163/187631295X00071 
Lanteri AA, del Río MG (2003) Revision of the genus Briarius [Fischer de Waldheim] (Coleoptera: Curculionidae). Insect Systematics \& Evolution 34(3): 281-294. https://doi. org/10.1163/187631203788964755

Lanteri AA, del Río MG (2004) Taxonomic revision of Thoracocyphus Emden (Coleoptera: Curculionidae). Insect Systematics \& Evolution 35(4): 449-456. https://doi. org/10.1163/187631204788912454

Lanteri AA, del Río MG (2005) Taxonomy of the monotypic genus Trichaptus Pascoe (Coleoptera: Curculionidae: Entiminae), a potential weevil mimic of Mutillidae. The Coleopterists Bulletin 59(1): 47-54. https://doi.org/10.1649/683

Lanteri AA, del Río MG (2006a) Taxonomic revision of the genus Cyphopsis Roelofs (Coleoptera, Curculionidae). Mitteilungen aus dem Museum für Naturkunde in Berlin. Deutsche Entomologische Zeitschrift 53: 275-281. https://doi.org/10.1002/mmnd.200600025

Lanteri AA, del Río MG (2006b) Taxonomic revision of the monotypic genus Acyphus Heller (Coleoptera: Curculionidae) with comments on infraspecific variation. Zootaxa 1312(1): 59-68. https://doi.org/10.11646/zootaxa.1312.1.5

Lanteri AA, del Río MG (2008) Caracteres genitales de la hembra en la clasificación y filogenia de la tribu Naupactini (Coleoptera: Curculionidae). In: Contribuciones taxonómicas en órdenes de insectos hiperdiversos. UNAM-RIBES-CYTED, 159-176.

Lanteri AA, del Río MG (2016a) Phylogeny of the tribe Naupactini (Coleoptera: Curculionidae) based on morphological characters. Systematic Entomology 42(2): 429-447. https://doi.org/10.1111/syen.12223

Lanteri AA, del Río MG (2016b) Taxonomy and cladistics of the group of genera related to Cyrtomon Schoenherr (Coleoptera: Curculionidae: Naupactini). Revista de la Sociedad Entomológica Argentina 75: 387-402. https://www.biotaxa.org/RSEA/article/view/22298

Lanteri AA, del Río MG (2017) Naupactus xanthographus (Germar) species group (Curculionidae: Entiminae: Naupactini): a comprehensive taxonomic treatment. Journal of Natural History 51(27-28): 1557-1587. https://doi.org/10.1080/00222933.2017.1346715

Lanteri AA, Díaz NB (1994) Systematic study and cladistic analysis of the genus Aramigus Horn (Coleoptera: Curculionidae). Transactions of the American Entomological Society 120: 113-144. https://www.jstor.org/stable/40785183

Lanteri AA, Loiácono MS (1990) Systematic study of the Pantomorus viridisquamosus species group (Coleoptera: Curculionidae). Insecta Mundi 4: 1-10. https://digitalcommons.unl.edu/insectamundi/396

Lanteri AA, Marvaldi AE (1995) Graphognathus Buchanan a new synonym of Naupactus Dejean and systematics of the N. leucoloma species group (Coleoptera: Curculionidae). The The Coleopterists Bulletin 49: 206-228. https://www.jstor.org/stable/4009138

Lanteri AA, Morrone JJ (1991) Cladistic analysis of Priocyphus Hustache and related genera (Coleoptera: Curculionidae). Proceedings of the Entomological Society of Washington 93: 278-287. https://biodiversitylibrary.org/page/16197951

Lanteri AA, Morrone JJ (1995) Cladistics of the Naupactus leucoloma species group, Atrichonotus, and Eurymetopus (Coleoptera: Curculionidae). Revista de la Sociedad Entomológica Argentina 54: 99-112. https://www.biotaxa.org/RSEA/article/view/33786 
Lanteri AA, Normark BB (1995) Parthenogenesis in the tribe Naupactini (Coleoptera: Curculionidae). Annals of the Entomological Society of America 88(6): 722-731. https:// doi.org/10.1093/aesa/88.6.722

Lanteri AA, O’Brien CW (1990) Taxonomic revision and cladistic analysis of Atrichonotus Buchanan (Coleoptera: Curculionidae). Transactions of the American Entomological Society 116: 697-725. https://www.jstor.org/stable/25078526

Lanteri AA, Guedes JC, Parra JRP (2002) Weevils injurious for roots of Citrus in São Paulo state, Brazil. Neotropical Entomology 31(4): 561-569. https://doi.org/10.1590/S1519566X2002000400008

Lanteri AA, Guzmán NV, del Río MG, Confalonieri VA (2013) Potential geographic distributions and successful invasions of parthenogenetic broad-nosed weevils (Coleoptera: Curculionidae) native to South America. Environmental Entomology 42(4): 677-687. https://doi.org/10.1603/EN12297

Lanteri AA, Loiácono MS, Coscarón M del C, Díaz NB (2017) Systematic study of the Pantomorus auripes species group (Coleoptera: Curculionidae). Revista de la Sociedad Entomológica Argentina 49: 3-16. https://www.biotaxa.org/RSEA/article/view/33985

Lázaro HO, Nasca AJ, Frascarolo D, Lemme MC, Labatte de Rudelli ME (1997) Promecops claviger (Coleoptera: Curculionidae): Nueva plaga de la soja en Tucumán, Argentina. Revista de la Sociedad Entomológica Argentina 56: 167-168. https://www.biotaxa.org/ RSEA/article/view/33683

Lázaro HO, Cruz D, Nasca AJ (1998) Promecops claviger Hustache (Coleoptera: Curculionidae): aspectos biológicos y daños al cultivo de la soja en Tucumán, R. Argentina. Acta Entomológica Chilena: 45-47. https://dialnet.unirioja.es/servlet/ articulo? codigo $=2013619$

LeConte JL (1874) The Classification of the Rhynchophorous Coleoptera. American Naturalist 8(8): 452-470. https://doi.org/10.1086/271360

LeConte JL, Horn GH (1876) The Rhynchophora of America, North of Mexico. Proceedings of the American Philosophical Society 15(96): [vii-ix + xi-xvi+] 1-442. https://www. jstor.org/stable/982412

Linnaeus C von (1758) Systema Naturae per Regna Tria Naturae: Secundum Classes, Ordines, Genera, Species, Cum Characteribus, Differentiis, Synonymis, Locis. Impensis Direct (Vol. 1). Laurentii Salvii, Holmiae, 824 pp. https://biodiversitylibrary.org/page/726886

Lona C (1938) Curculionidae: Otiorrhynchinae III. Coleopterorum Catalogus. Dr. W. Junk Verlag für Naturwissenschaften, 's-Gravenhage, 415-600.

Marshall GAK (1916) On new Neotropical Curculionidae. Annals \& Magazine of Natural History 8(108): 449-469. https://doi.org/10.1080/00222931609486900

Marshall GAK (1922a) Some injurious Neotropical weevils (Curculionidae). Bulletin of Entomological Research 13(1): 59-71. https://doi.org/10.1017/S0007485300045247

Marshall GAK (1922b) VI. On new genera and species of Neotropical Curculionidae. Transactions of the Royal Entomological Society of London 1922-1923: 181-224. https://doi. org/10.1111/j.1365-2311.1922.tb02830.x [+ pl. III-I]

Marshall GAK (1926) LXVI - On new Neotropical Curculionidae (Col.). Annals \& Magazine of Natural History 9(107): 530-543. https://doi.org/10.1080/00222932608633549 
Marvaldi AE (1997) Higher level phylogeny of Curculionidae (Coleoptera: Curculionoidea) based mainly on larval characters, with special reference to broad-nosed weevils. Cladistics 13(4): 285-312. https://doi.org/10.1111/j.1096-0031.1997.tb00321.x

Marvaldi AE (1998) Larvae of Entiminae (Coleoptera: Curculionidae): tribal diagnoses and phylogenetic key, with a proposal about natural groups within Entimini. Insect Systematics \& Evolution 29(1): 89-98. https://doi.org/10.1163/187631298X00212

Marvaldi AE, Lanteri AA (2005) Key to higher taxa of South American weevils based on adult characters (Coleoptera, Curculionoidea). Revista Chilena de Historia Natural 78(1): 65-87. https://doi.org/10.4067/S0716-078X2005000100006

Marvaldi AE, Lanteri AA, del Río MG, Oberprieler RG (2014) Entiminae Schoenherr, 1823. In: Leschen RAB, Beutel RG (Eds) Handbook of Zoology, Arthropoda: Insecta: Coleoptera, Volume 3: Morphology and Systematics (Phytophaga). De Gruyter, Berlin, 503-522.

Marvaldi AE, del Río MG, Pereyra VA, Rocamundi N, Lanteri AA (2018) A combined molecular and morphological approach to explore the higher phylogeny of entimine weevils (Coleoptera: Curculionidae), with special reference to South American taxa. Diversity (Basel) 10(3): e95. https://doi.org/10.3390/d10030095

Mazo-Vargas A (2011) Untangling the effects of biogeography and host plant associations: phylogenetic and phylogeographic studies in the Exophthalmus genus complex. Master of Science Thesis. University of Puerto Rico, at Mayaguez.

Ministerio del Medio Ambiente, Departamento Nacional de Planeación, Instituto Alexander von Humboldt (1996) Política Nacional de Biodiversidad. https://www.minambiente. gov.co/images/BosquesBiodiversidadyServiciosEcosistemicos/pdf/Politica-Nacionalde-Biodiversidad/politica_nacional-biodiversidad.pdf

Morrone JJ (1999) The species of Entiminae (Coleoptera: Curculionidae) ranged in America South of the United States. Anales del Instituto de Biología. Serie Zoología 70(2): 99-168. http://revistas.unam.mx/index.php/zoo/article/view/7224

Morrone JJ (2002) The Neotropical weevil genus Entimus (Coleoptera: Curculionidae: Entiminae): cladistics, biogeography, and modes of speciation. The Coleopterists Bulletin 56(4): 501-513. https://doi.org/10.1649/0010-065X(2002)056[0501:TNWGEC]2.0.CO;2

Morrone JJ, Abadie EI, Godinho Jr C (2019) A new species of Entimus Germar (Coleoptera: Curculionidae: Entiminae) from southeastern Brazil. Zootaxa 4590(1): 191-195. https://doi.org/10.11646/zootaxa.4590.1.10

O’Brien CW, Kovarik PW (2001) The genus Diaprepes: its origin and geographical distribution in the Caribbean region. https://irrec.ifas.ufl.edu/flcitrus/short_course_and_workshop/diaprepes/Genus_diaprepes.shtml

O’Brien CW, Peña J (2012) Two species of Compsus Schoenherr, new citrus pests from Colombia (Coleoptera: Curculionidae: Entiminae). Insecta Mundi 0227: 1-13. https:// digitalcommons.unl.edu/insectamundi/736

O’Brien CW, Wibmer GJ (1982) Annotated checklist of the weevils (Curculionidae sensu lato) of North America, Central America, and the West Indies (Coleoptera: Curculionoidea). Memoirs of the American Entomological Institute 34: 1-382.

Oberprieler RG, Marvaldi AE, Anderson RS (2007) Weevils, weevils, weevils everywhere. Zootaxa 1668(1): 491-520. https://doi.org/10.11646/zootaxa.1668.1.24 
Olivier GA (1790) Encyclopédie méthodique. Histoire naturelle. Insectes. Volume 5. Chez Panckoucke, Librarie, Paris, 793 pp. https://www.biodiversitylibrary.org/page/7577222

Olivier GA (1807) Entomologie, ou Histoire naturelle des insectes: avec leurs caractères génériques et spécifiques, leur description, leur synonymie, et leur figure enluminée. Coléoptères. Tome Cinquieme. De l'Imprimerie de Baudoin, Paris, 612 pp. https://doi. org/10.5962/bhl.title.61905

Pascoe FP (1872) Contributions towards a knowledge of the Curculionidae. Part III. Zoological Journal of the Linnean Society 11(55): 440-492. https://doi. org/10.1111/j.1096-3642.1872.tb01668.x

Pascoe FP (1880) New Neotropical Curculionidae. Part I. Annals and Magazine of Natural History 5(29): 419-428. https://doi.org/10.1080/00222938009459433

Pascoe FP (1881) VI- New neotropical Curculionidae. Part IV. Annals and Magazine of Natural History. Series 5. 7(37): 38-45. https://doi.org/10.1080/00222938109459470

Peña LA (2001) Gusanos blancos de la papa, biología y manejo. Innovación y cambio tecnológico 2: 29-33.

Perty M (1832) Insecta Brasiliensia. Delectus animalium articulatorum, quae in itinere per Brasiliam, annis MDCCCXVII-MDCCCXX: jussu et auspiciis Maximiliani Josephi I. Impensis Editoris, Monachii, 190 pp. https://www.biodiversitylibrary.org/page/57932830

Pierce WD (1913) Miscellaneous contributions to the knowledge of the weevils of the families Attelabidae and Brachyrhinidae. Proceedings of the United States National Museum 45: 365-426. https://doi.org/10.5479/si.00963801.1988.365

Pierce WD (1914) New potato weevils from Andean South America. Journal of Agricultural Research 1: 347-352. [ + pl. XXXDC-XLI] https://naldc.nal.usda.gov/download/ IND43965426/PDF

Poinar Jr G, Brown AE (2011) Descriptions of a broad-nosed weevil (Eudiagogini: Curculionidae) and false ladybird beetle (Nilionini: Nilionidae) in Dominican amber. Historical Biology 23(2-3): 231-235. https://doi.org/10.1080/08912963.2010.527159

Poinar G, Legalov AA (2017) Five new species from the subfamily Entiminae (Coleoptera: Curculionidae) in Dominican amber. Palaeontologia Electronica 20: 1-13. https://doi. $\operatorname{org} / 10.26879 / 698$

Poinar G, Bukejs A, Legalov AA (2017) First records of weevils (Coleoptera: Curculionidae) in Quaternary Colombian copal. Revista Colombiana de Entomologia 43(1): 85-90. https://doi.org/10.25100/socolen.v43i1.6654

R Core Team (2018) R: A language and environment for statistical computing. R Foundation for Statistical Computing, Vienna. https://www.R-project.org/

Regueira JCS, Damasceno EM, Iannuzzi L (2020) Shape variation of Cydianerus latruncularius (Coleoptera, Curculionidae) across biomes and sexes. Zoologischer Anzeiger 289: 96-107. https://doi.org/10.1016/j.jcz.2020.10.002

Rocha Barreto M, Cavalet F (2016) Promecops claviger Hustache, 1929 (Coleoptera: Curculionidae): first register in Brazil and first host plant register. Check List 7(5): 616-620. https://doi.org/10.15560/7.5.616

Romo A, Morrone JJ (2011) Track analysis of the Neotropical Entimini (Coleoptera: Curculionidae: Entiminae). Revista Brasileira de Entomologia 55(3): 313-316. https://doi. org/10.1590/S0085-56262011005000034 
Rosas MV, Morrone JJ, del Río MG, Lanteri AA (2011) Phylogenetic analysis of the Pantomorus-Naupactus complex (Coleoptera: Curculionidae: Entiminae) from North and Central America. Zootaxa 2780(1): 1-19. https://doi.org/10.11646/zootaxa.2780.1.1

RStudio Team (2016) RStudio: Integrated Development for R. RStudio, Inc., Boston. http:// www.rstudio.com/

Sahlberg CR (1823) Periculi entomographici, species insectorum nondum descriptas proposituri, fasciculus. Frenckel, Aboae, $82 \mathrm{pp}$. https://www.biodiversitylibrary.org/ page/10990686

Say T (1824) Descriptions of coleopterous insects collected in the late expedition to the Rocky Mountains, performed by order of Mr. Calhoun, Secretary of War, under the command of Major Long. By Thomas Say, Zoologist to the Expedition. Journal of the Academy of Natural Sciences of Philadelphia 3: 139-216. https://www.biodiversitylibrary.org/page/24668950

Scataglini MA, Lanteri AA, Confalonieri VA (2005) Phylogeny of the Pantomorus-Naupactus complex based on morphological and molecular data (Coleoptera: Curculionidae). Cladistics 21(2): 131-142. https://doi.org/10.1111/j.1096-0031.2005.00055.x

Schönherr CJ (1823) Curculionides [Tabula synoptica familiae Curculionidum]. Isis von Oken 1823: 1132-1146. https://biodiversitylibrary.org/page/13257284

Schönherr CJ (1834) Genera et species Curculionidum, cum synonymia hujus familiae. Species novae aut hactenus minus cognitae, descriptionibus a Dom. Leonardo Gyllenhal, C. H. Boheman, et entomologis aliis illustratae, tomus secundus, pars prima. Roret, Paris, 673 pp. https://doi.org/10.5962/bhl.title.8952

Schönherr CJ (1840a) Genera et species Curculionidum, cum synonymia hujus familiae. Species novae aut hactenus minus cognitae, descriptionibus a Dom. Leonardo Gyllenhal, C. H. Boheman, et entomologis aliis illustratae, tomus quintus, pars prima. Roret, Paris, 974 pp. https://www.biodiversitylibrary.org/page/4110075

Schönherr CJ (1840b) Genera et species Curculionidum, cum synonymia hujus familiae. Species novae aut hactenus minus cognitae, descriptionibus a Dom. Leonardo Gyllenhal, C. H. Boheman, et entomologis aliis illustratae, tomus sextus, pars prima. Roret, Paris, 474 pp. https://www.biodiversitylibrary.org/page/4114879

Schönherr CJ (1842) Genera et species Curculionidum, cum synonymia hujus familiae. Species novae aut hactenus minus cognitae, descriptionibus a Dom. Leonardo Gyllenhal, C. H. Boheman, et entomologis aliis illustratae, tomus sextus, pars secunda. Roret, Paris, 495 pp. https://www.biodiversitylibrary.org/page/4115130

Schönherr CJ (1845) Genera et species Curculionidum, cum synonymia hujus familiae. Species novae aut hactenus minus cognitae, descriptionibus a Dom. Leonardo Gyllenhal, C. H. Boheman, et entomologis aliis illustratae, tomus octavus, pars secunda. Roret, Paris, 504 pp. https://www.biodiversitylibrary.org/page/4114205

Schönherr CJ (1847) Mantissa secunda familiae curculionidum. Seu descriptiones novorum quorundam generum curculionidum. Typis Norstedt et filii, Holmiae, 86 pp. https://doi. org/10.5962/bhl.title.5794

Scudder SH (1876) Fossil Coleoptera from the Rocky Mountain Tertiaries. Bulletin of the United States Geological and Geographical Survey of the Territories 2: 77-87. https:// www.biodiversitylibrary.org/page/32141159 
Sharp D, Champion GC (1911) Biologia Centrali-Americana. Insecta. Coleoptera. Rhynchophora. Volume 4, part 3. R. H. Porter, London, 354 pp. [+ pl. 15] https://biodiversitylibrary.org/page/581470

Shorthouse DP (2010) SimpleMappr, an online tool to produce publication-quality point maps. https://www.simplemappr.net

Solano Rojas Y, Girón JC (2019) First record of Pandeleteius hadromeroides (Kirsch) (Coleoptera: Curculionidae: Entiminae: Tanymecini) on strawberry crops in Venezuela. The The Coleopterists Bulletin 73(4): 962-965. https://doi.org/10.1649/0010065X-73.4.962

Soto-Hernández M, Barros-Barrios MM (2018) Curculiónidos (Coleoptera: Curculionidae) en el cultivo de Nogal pecanero en el estado de Coahuila, México. Entomología Mexicana 5: 580-586. http://www.entomologia.socmexent.org/revista/2018/SM/SM\%20 580-586.pdf

Taschenberg EL (1870) Neue Käfer aus Colombien und Ecuador. Zeitschrift für die gesammten Naturwissenschaft 35: 177-199. https://babel.hathitrust.org/cgi/pt?id=hvd.32044 106244114\&view=1 up\&seq=191

Tennekes M (2018) tmap: Thematic Maps in R. Journal of Statistical Software 84(6): 1-39. https://doi.org/10.18637/jss.v084.i06

Thompson RT (1992) Observations on the morphology and classification of weevils (Coleoptera, Curculionoidea) with a key to major groups. Journal of Natural History 26(4): 835-891. https://doi.org/10.1080/00222939200770511

Van Dam MH, Lam AW, Sagata K, Gewa B, Laufa R, Balke M, Faircloth BC, Riedel A (2017) Ultraconserved elements (UCEs) resolve the phylogeny of Australasian smurf-weevils. PLoS One 12(11): e0188044. https://doi.org/10.1371/journal.pone.0188044

van Emden FI (1944a) L-A key to the genera of Brachyderinae of the World. Annals \& Magazine of Natural History 11(81): 559-586. https://doi.org/10.1080/00222934408527456

vanEmden FI(1944b)XLVII-A key to the genera of Brachyderinæ of the World. Annals \& Magazine of Natural History 11(80): 503-532. https://doi.org/10.1080/00222934408527452

Vanin SA (1983) Revision of Phaedropus Schoenherr with notes on the male genitalia of Entimini (Coleoptera: Curculionidae: Leptopiinae). The The Coleopterists Bulletin 37: 283-298. https://www.jstor.org/stable/4008033

Vanin SA, Gaiger F (2005) A cladistic analysis of the genera of the tribe Entimini (Coleoptera, Curculionidae), with description of a new genus and species from the Amazonian Region. Zootaxa 1053(1): 1-21. https://doi.org/10.11646/zootaxa.1053.1.1

Vaurie P (1951) Revision of the genus Entimus with notes on other genera of Entimini (Coleoptera Curculionidae). Revista Chilena de Entomología 1: 147-171. https://biodiversitylibrary.org/page/32160206

Vaurie P (1963) A revision of the South American genus Hyphantus (Coleoptera, Curculionidae, Otiorhynchinae). Bulletin of the American Museum of Natural History 125: 239-304. http://digitallibrary.amnh.org/handle/2246/1979

Voss E (1934) Einige unbeschriebene neotropische Curculioniden nebst einer Vorstudie zur tribus Promecopini (Col. Curc.). Sborník Entomologického Oddeleni Národního Musea v Praze 12: 63-104. http://aemnp.eu/PDF/12_0/12_0_63.pdf 
Voss E (1936) Uber einige exotische Curculioniden (Col., Curc). Bulletin de la Société des naturalistes luxembourgeois, N. S. 46: 103-124. https://www.snl.lu/publications/bulletin/SNL_1936_046_103_124.pdf

Voss E (1939) Über neue und wenig bekannte Rüssler-Arten aus der neotropischen Region, vorwiegend aus Brasilien (Coleoptera: Curculionidae). Arbeiten über morphologische und taxonomische entomologie aus Berlin-Dahlem 6: 335-340.

Voss E (1953) Neue und bemerkenswerte Curculioniden aus Colombien und Bolivien. (Col. Curc.). Entomologische Mitteilungen aus dem Zoologischen Museum Hamburg 1: 55-84. https://www.zobodat.at/pdf/Ent-Mitt-Zool-Mus-Hamburg_1_0055-0084.pdf

Warner RE (1979) The genus Eudiagogus (Coleoptera, Curculionidae, Leptopiinae), with two new species on the weed Sesbania (Leguminosae). Proceedings of the Entomological Society of Washington 81: 304-320. https://www.biodiversitylibrary.org/part/63464

Waterhouse CO (1879) Descriptions of new Coleoptera from Medellin, Colombia, recently added to the British Museum collection. Cistula Entomologica 2: 421-429. https://biodiversitylibrary.org/page/10891087

Wibmer GJ, O’Brien CW (1986a) Annotated checklist of the weevils (Curculionidae sensu lato) of South America (Coleoptera: Curculionoidea). Memoirs of the American Entomological Institute 39: 1-563.

Wibmer GJ, O’Brien CW (1986b) Geonemus Schoenherr, 1833 and Brachyomus Lacordaire, 1863 (Insecta, Coleoptera): Proposal to maintain current usage by designation of a type species for Geonemus. ZN (S.) 2565. Bulletin of Zoological Nomenclature 43: 300-302. https://doi.org/10.5962/bhl.part.454

Wilts BD, Michielsen K, Kuipers J, De Raedt H, Stavenga DG (2012) Brilliant camouflage: Photonic crystals in the diamond weevil, Entimus imperialis. Proceedings of the Royal Society B: Biological Sciences 279(1738): 2524-2530. https://doi.org/10.1098/rspb.2011.2651

Zhang G, Basharat U, Matzke N, Franz NM (2017) Model selection in statistical historical biogeography of Neotropical insects-The Exophthalmus genus complex (Curculionidae: Entiminae). Molecular Phylogenetics and Evolution 109: 226-239. https://doi. org/10.1016/j.ympev.2016.12.039

\section{Supplementary material 1}

DarwinCore-formatted list of species of Entiminae recorded from Colombia. This checklist is available via GBIF (Girón 2020, https://doi.org/10.15472/jdwfao) Authors: Jennifer C. Girón

Data type: Species list

Copyright notice: This dataset is made available under the Open Database License (http://opendatacommons.org/licenses/odbl/1.0/). The Open Database License $(\mathrm{ODbL})$ is a license agreement intended to allow users to freely share, modify, and use this Dataset while maintaining this same freedom for others, provided that the original source and author(s) are credited.

Link: https://doi.org/10.3897/neotropical.15.59713.suppl1 


\section{Supplementary material 2}

DarwinCore-formatted occurrence records for 749 entimine specimens deposited in Colombian biological collections

Authors: Jennifer C. Girón

Data type: Occurrence data

Copyright notice: This dataset is made available under the Open Database License (http://opendatacommons.org/licenses/odbl/1.0/). The Open Database License $(\mathrm{ODbL})$ is a license agreement intended to allow users to freely share, modify, and use this Dataset while maintaining this same freedom for others, provided that the original source and author(s) are credited.

Link: https://doi.org/10.3897/neotropical.15.59713.suppl2 